\title{
Synthetic Approach Towards the Total Synthesis of Kempane Diterpenes via Transannular Diels-Alder Strategy
}

Franck Caussanel, Keyan Wang, Sreekanth A. Ramachandran and Pierre Deslongchamps*

\section{List of contents:}

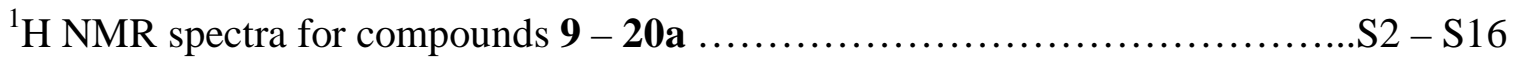

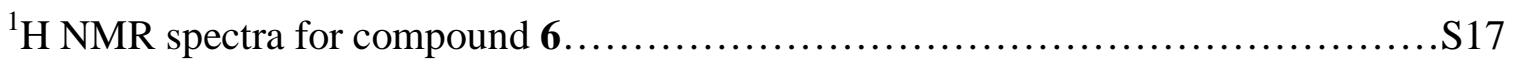

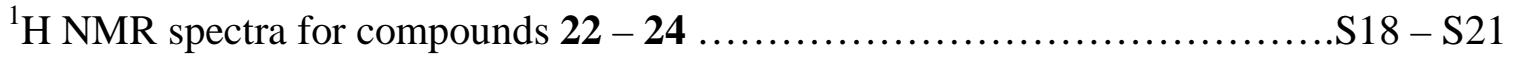

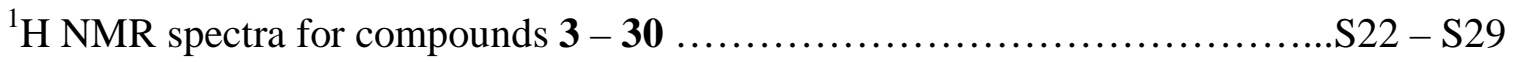

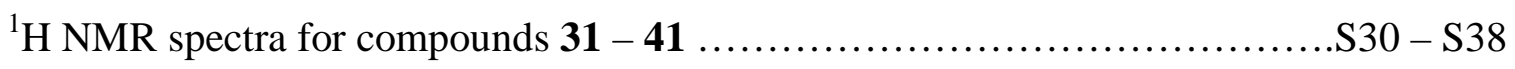

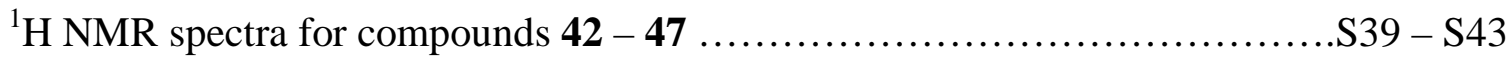

General methods, preparation and characterization data for compounds $\mathbf{9}-\mathbf{2 0}$...S44 - S53

Preparation and characterization data for compounds $7 \& \mathbf{6} \ldots \ldots \ldots \ldots \ldots . . . \ldots 52-$ S5 3

ORTEP diagram and crystal data for compound $\mathbf{3 0} \ldots \ldots \ldots \ldots \ldots \ldots \ldots \ldots \ldots . . . \ldots 54-$ S56

ORTEP diagram and crystal data for compound $37 \ldots \ldots \ldots \ldots \ldots \ldots \ldots \ldots . . . . \ldots 57$. S59 

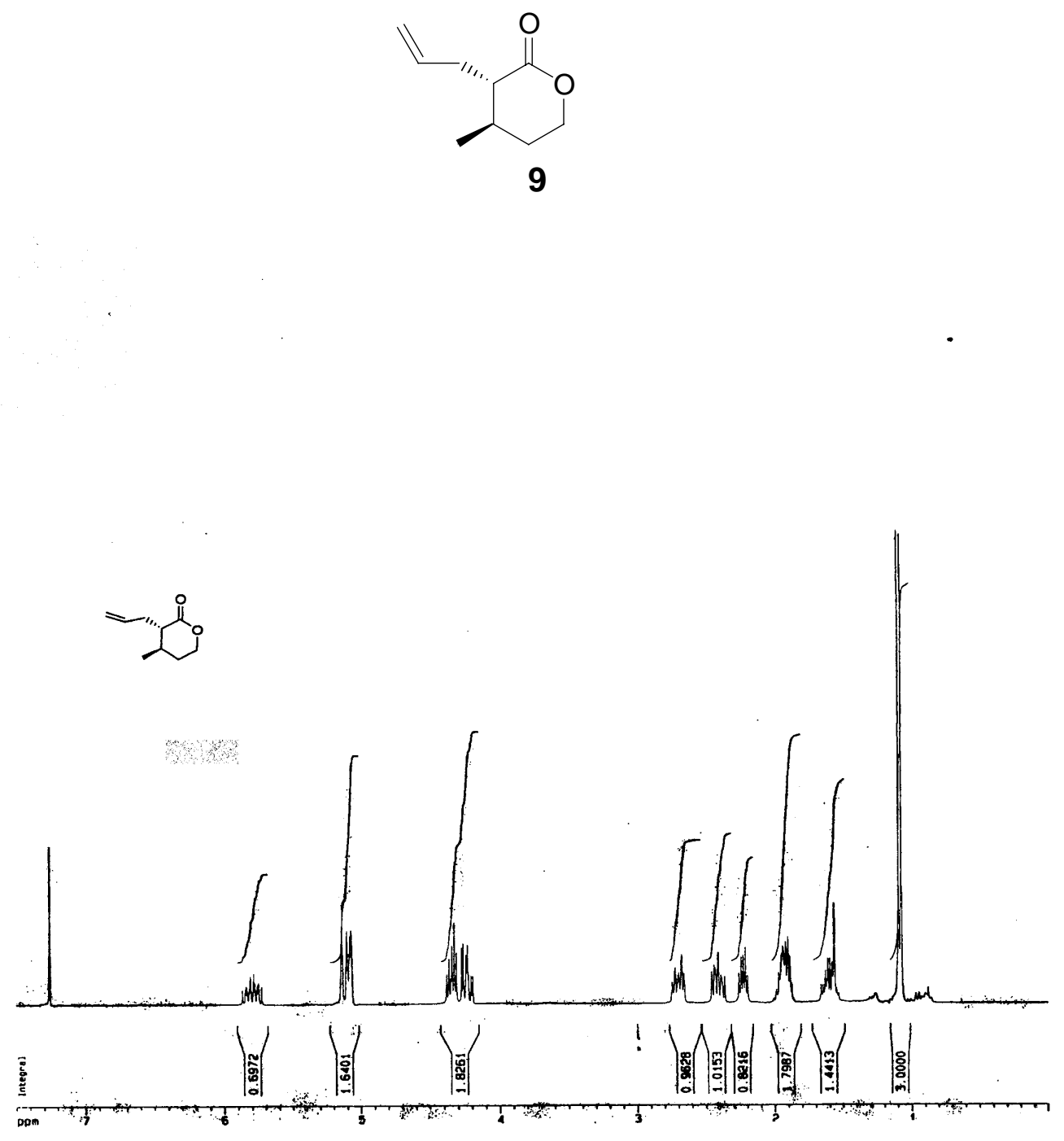

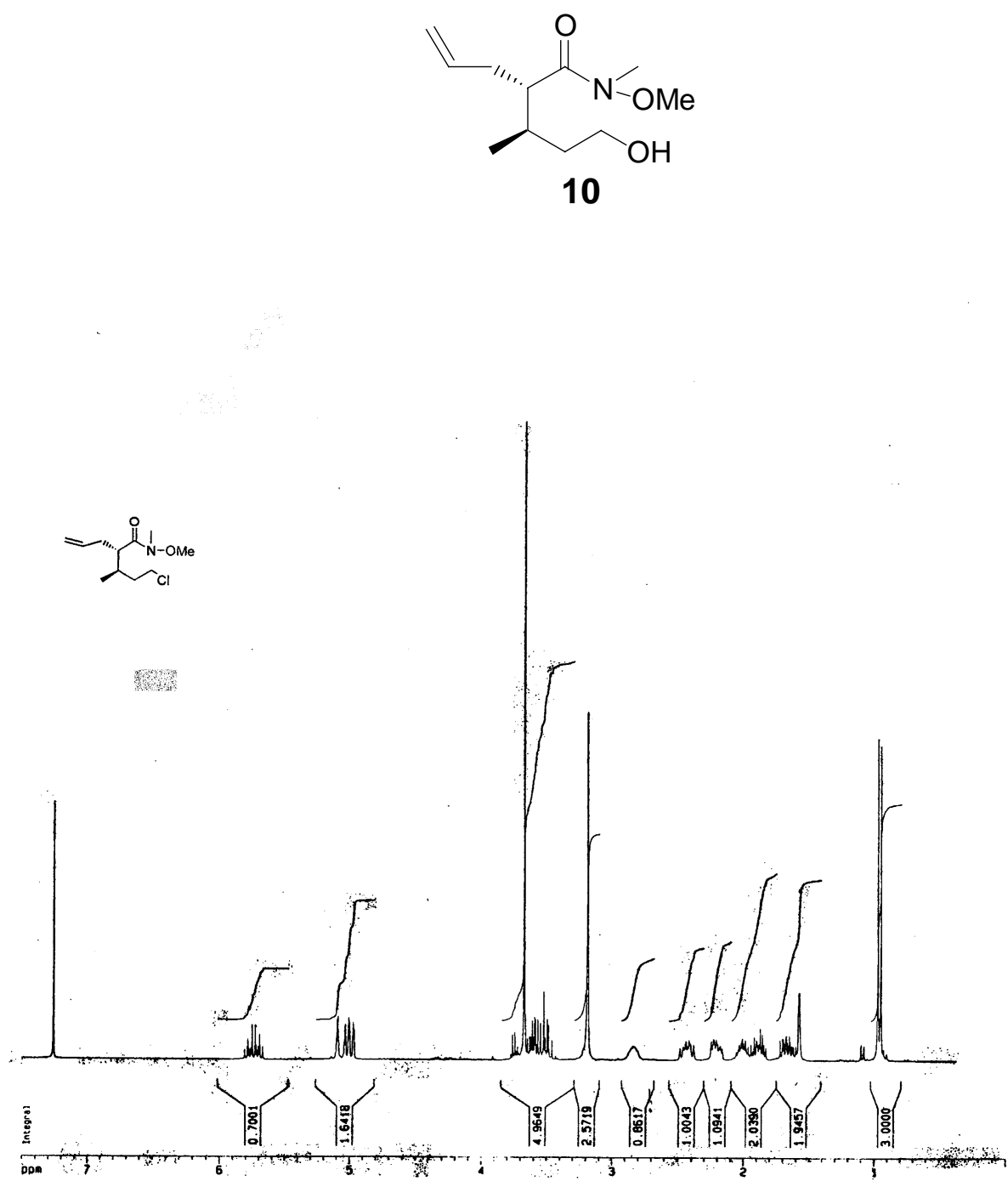


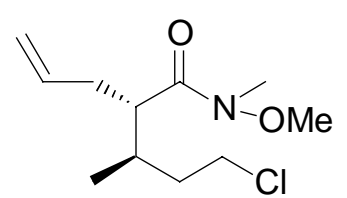

11
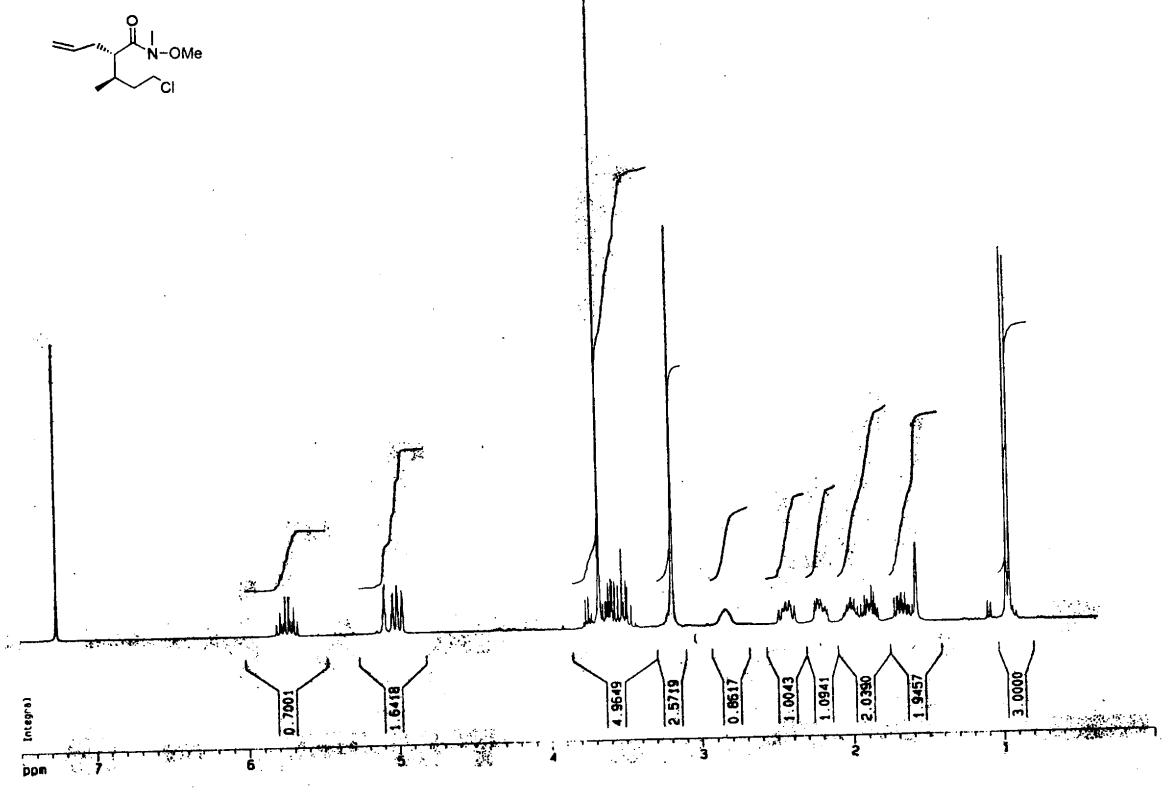

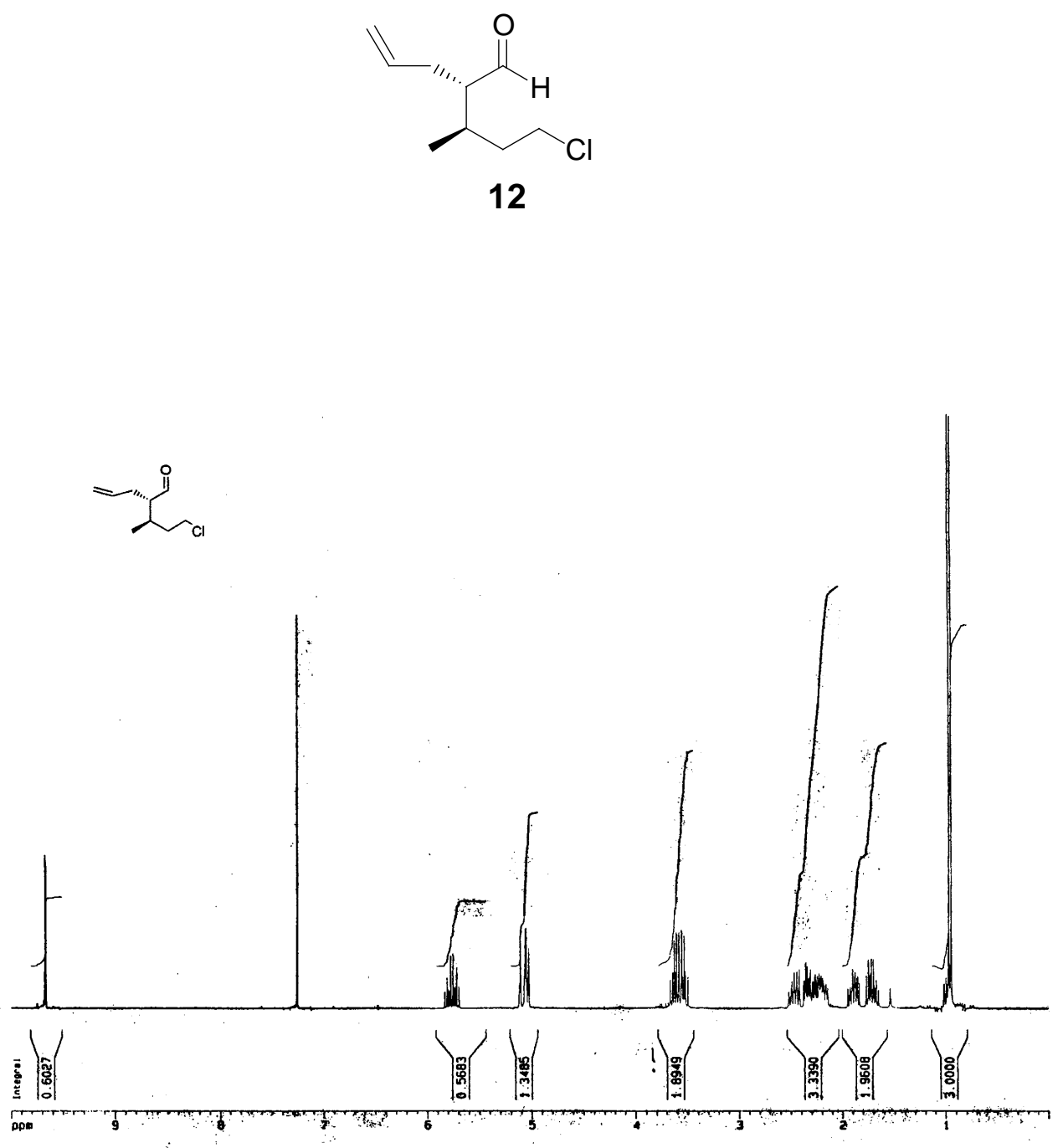


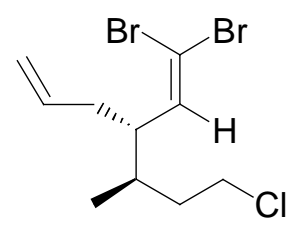

13

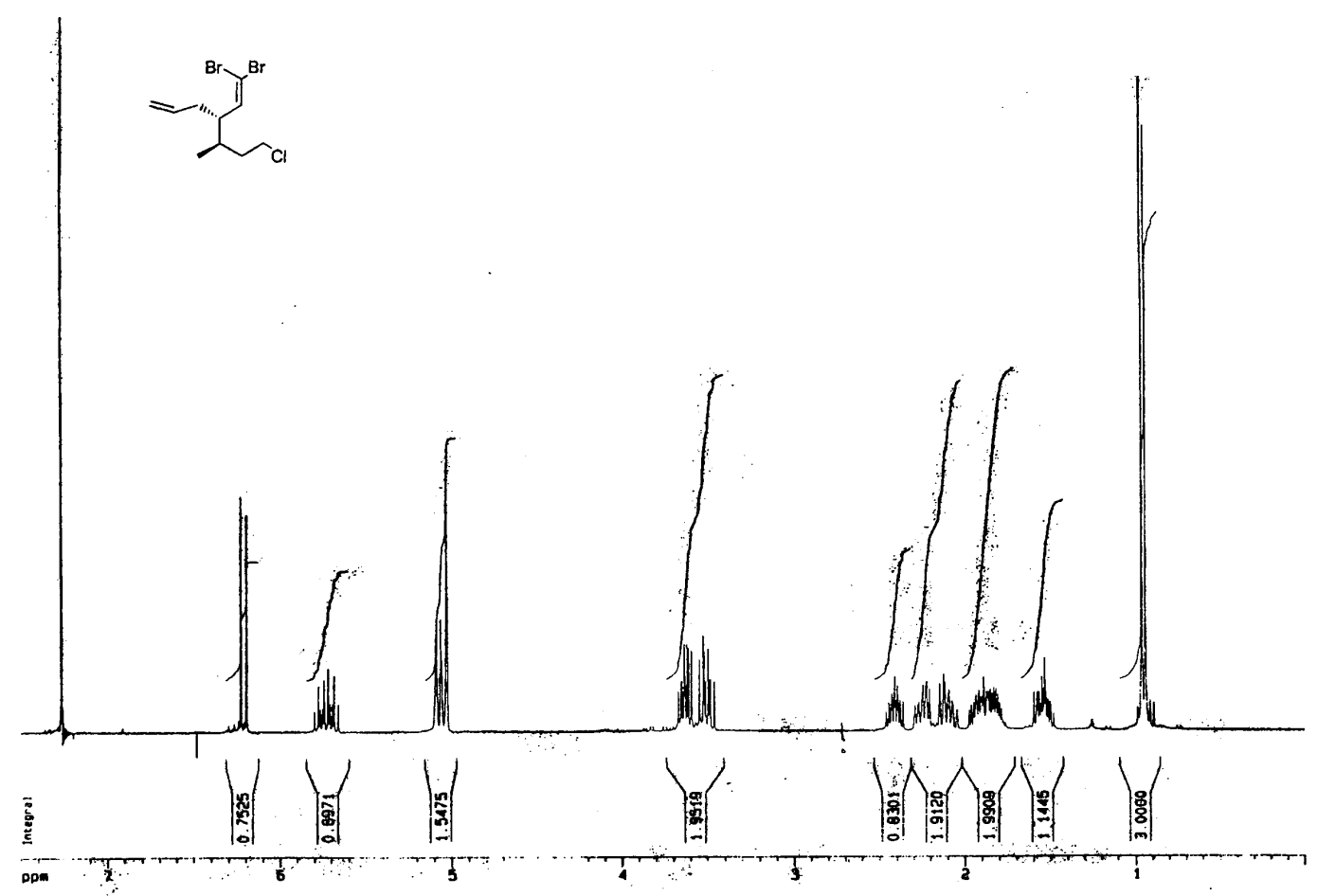




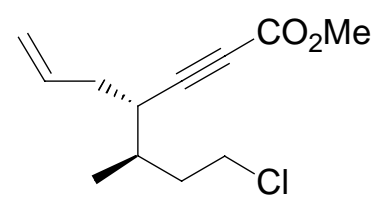

14
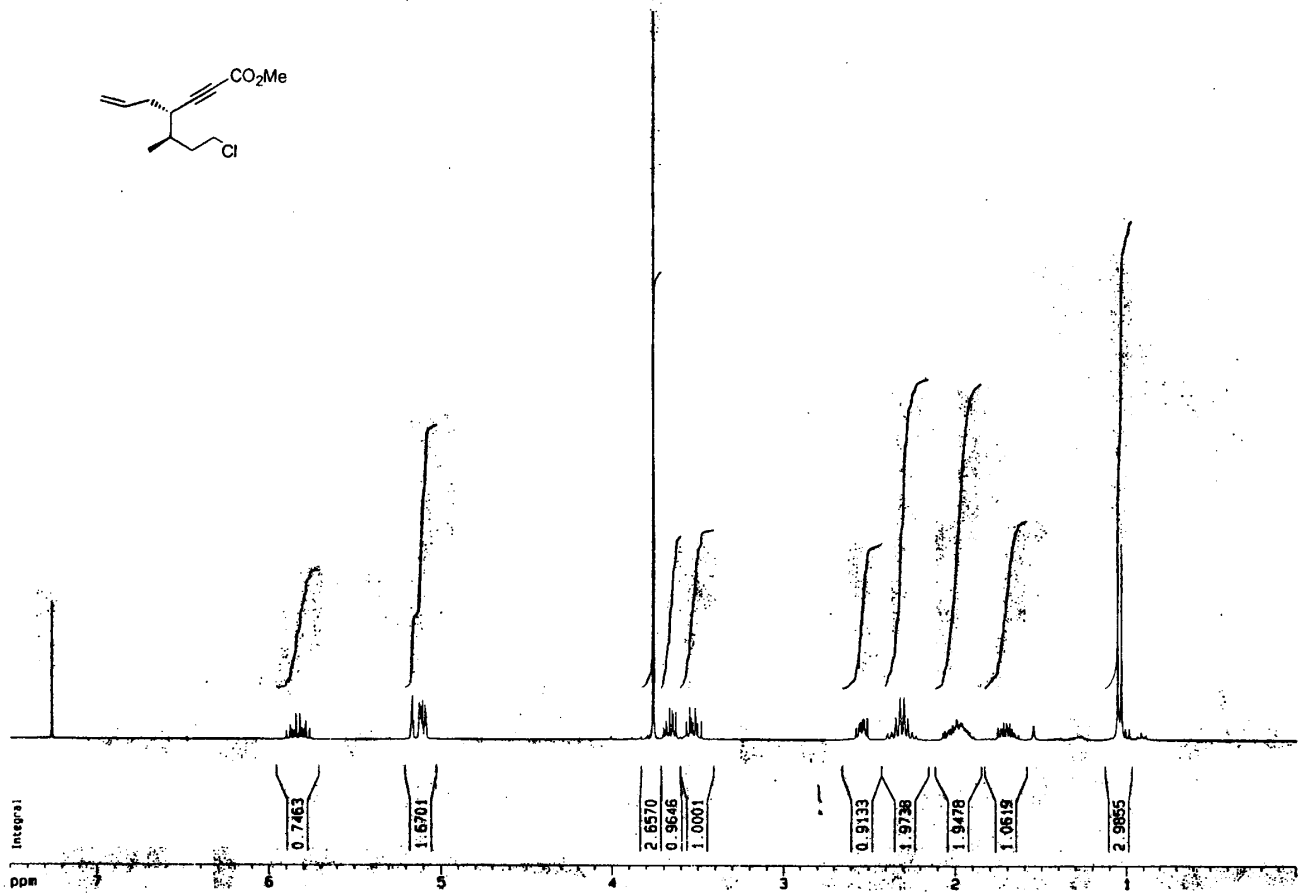


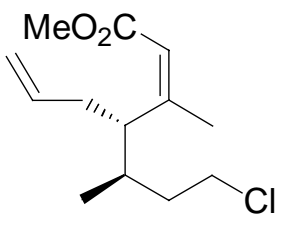

15

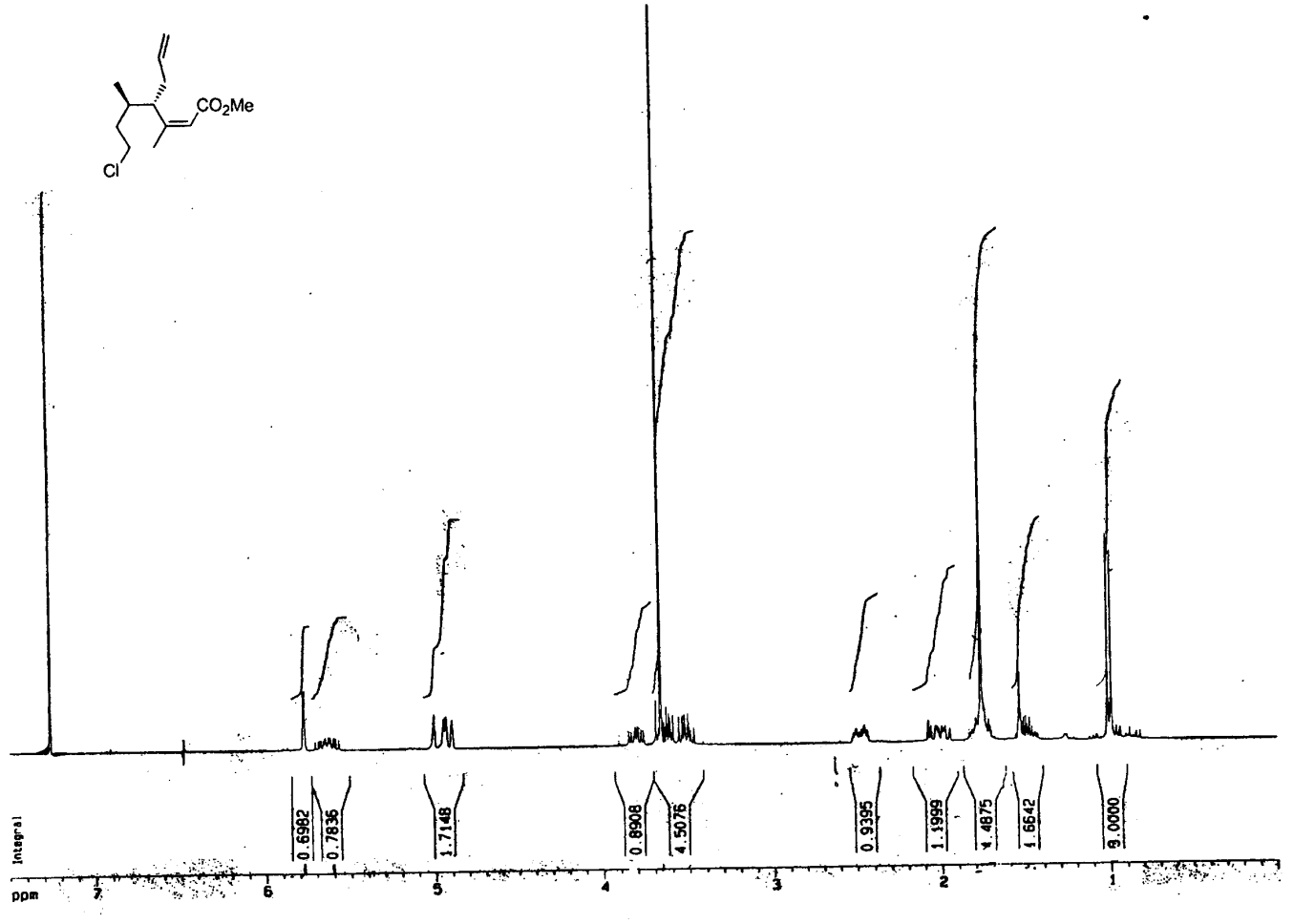




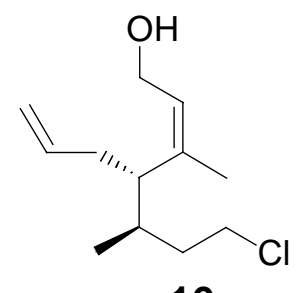

16

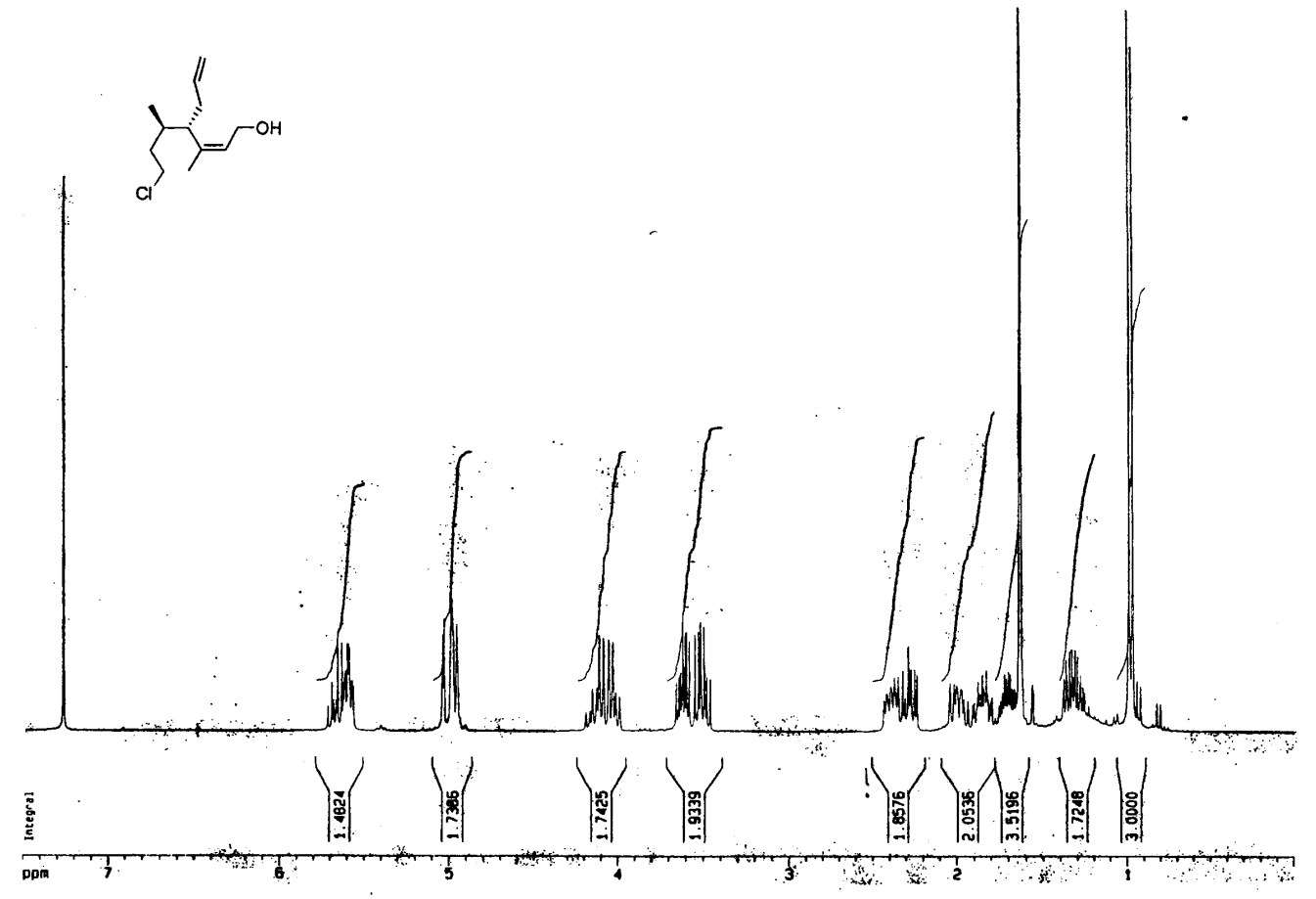



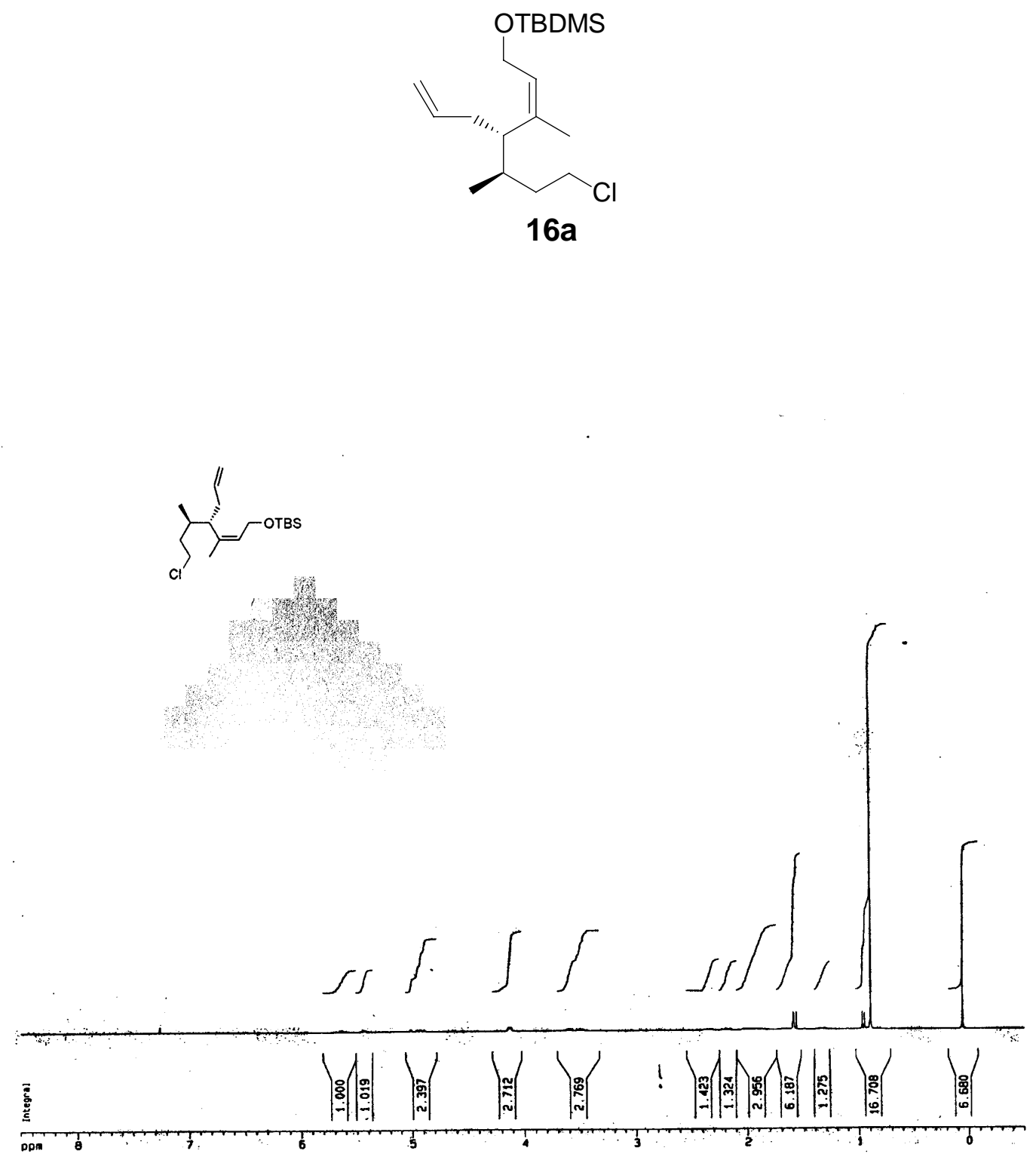

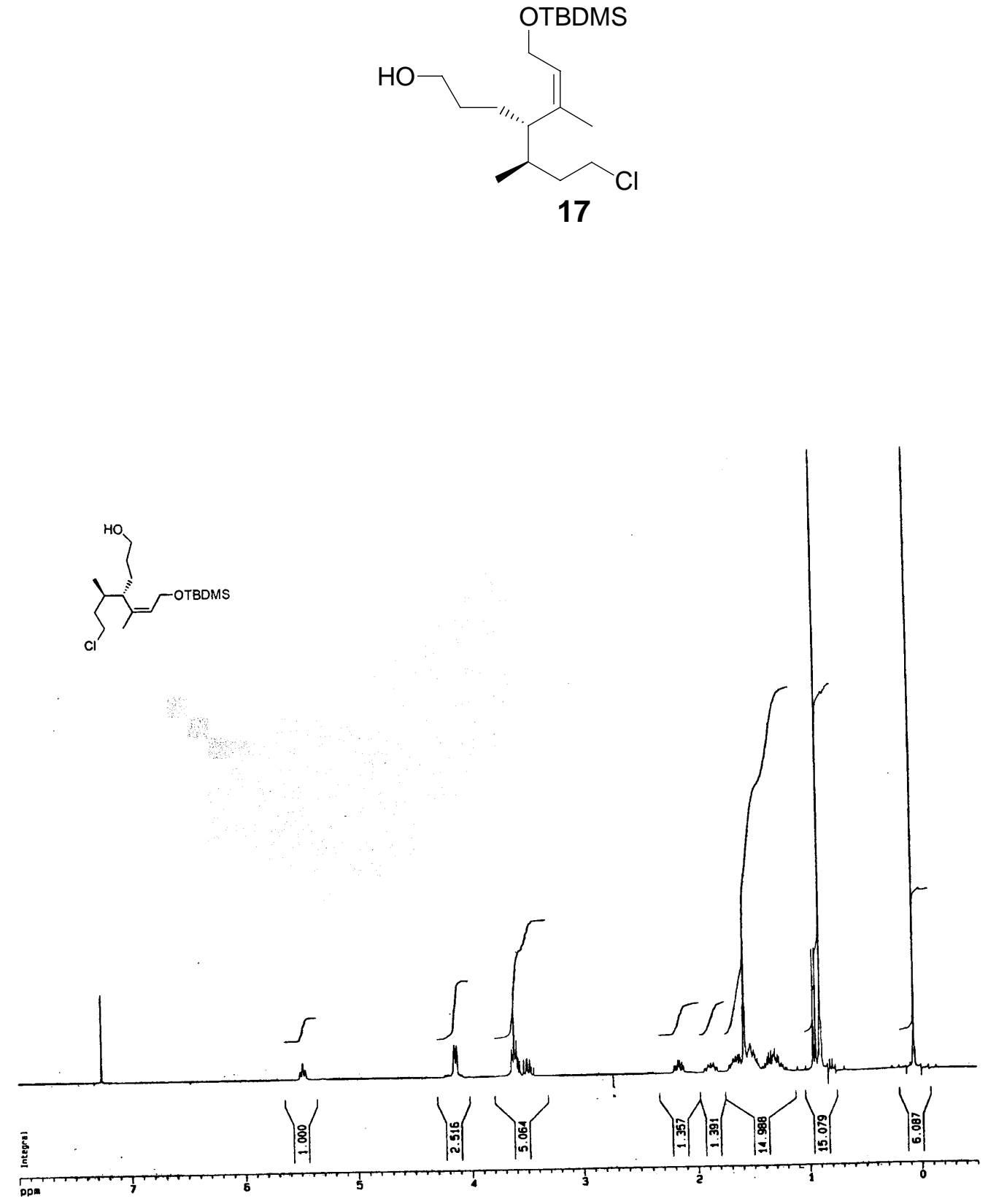


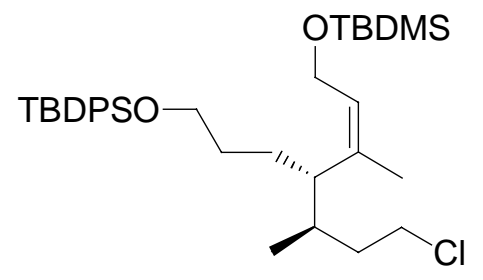

$17 a$

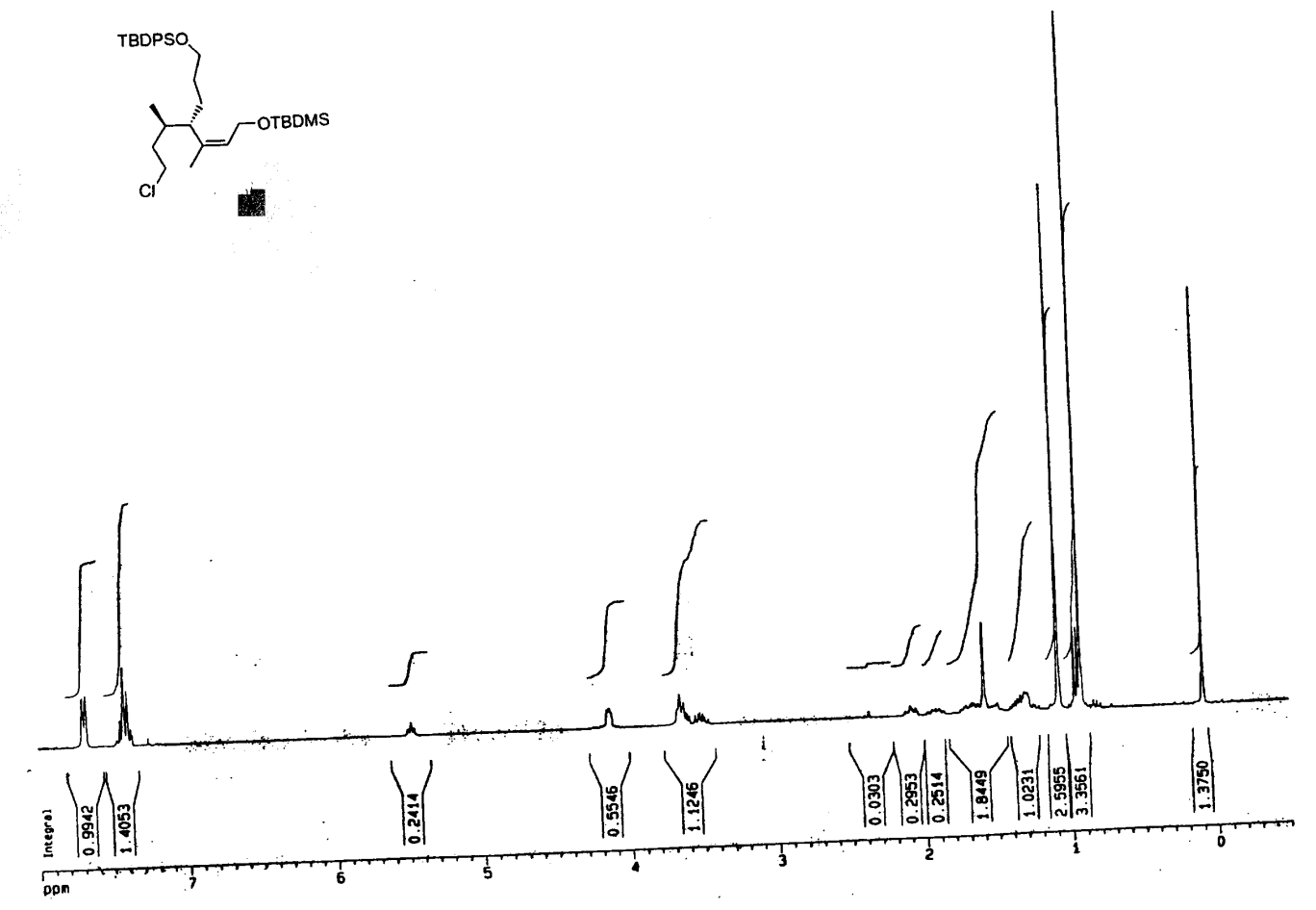




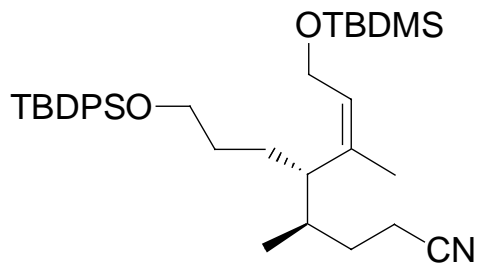

18

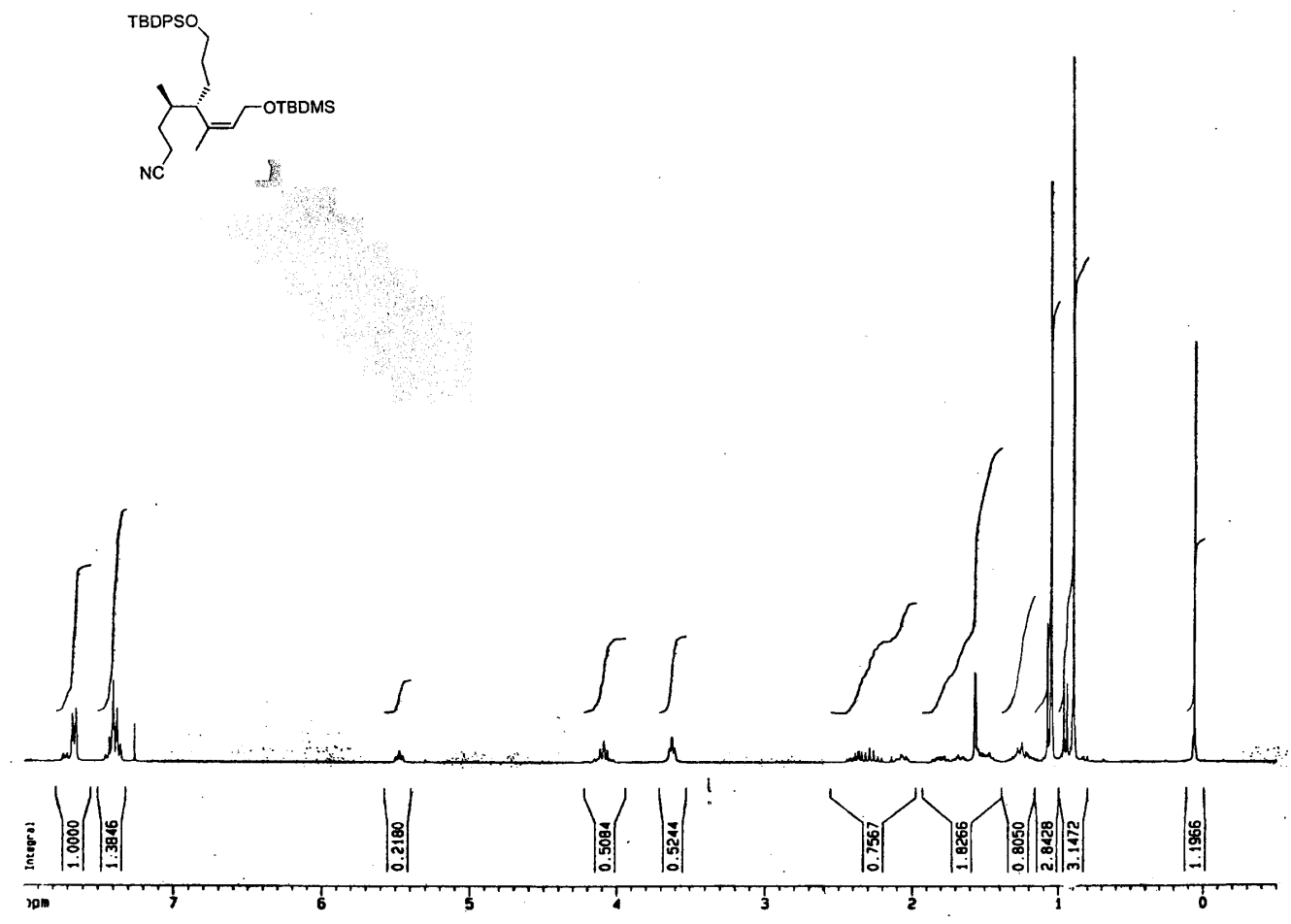




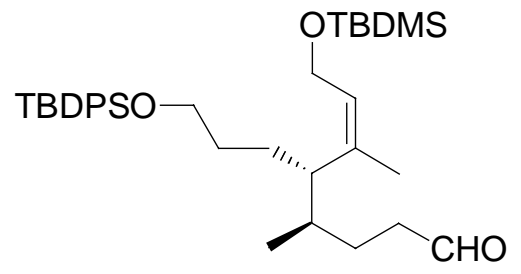

19

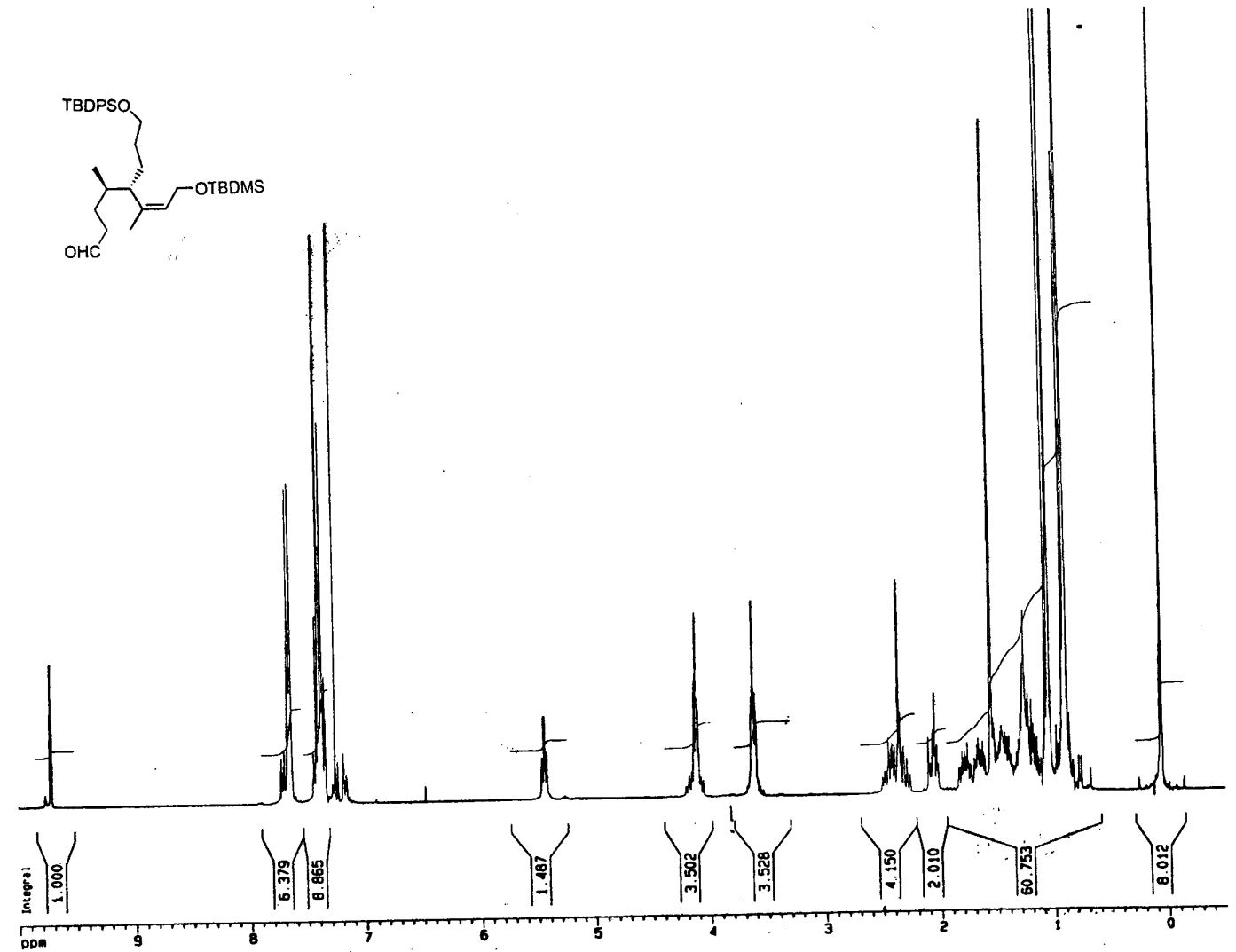



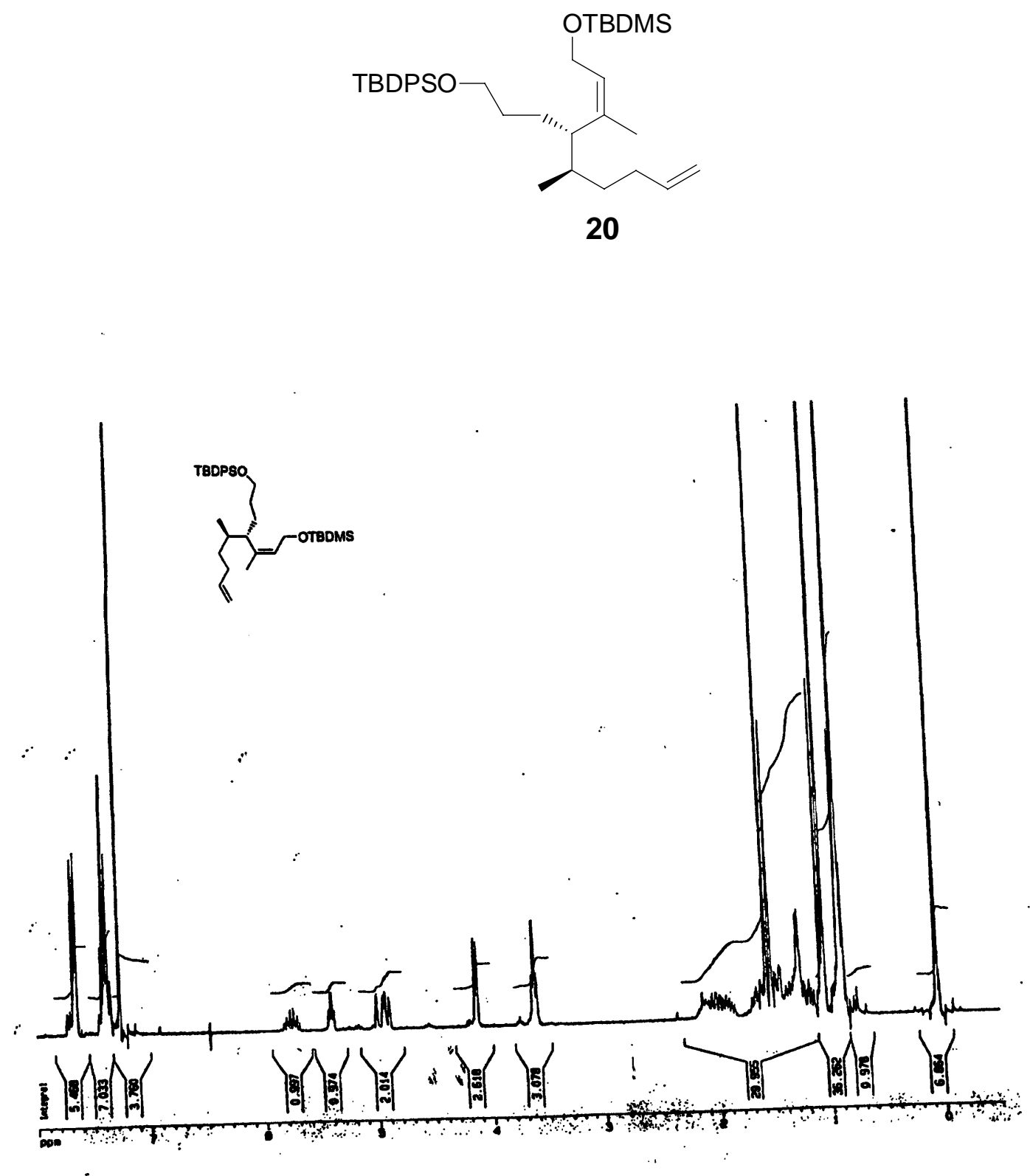

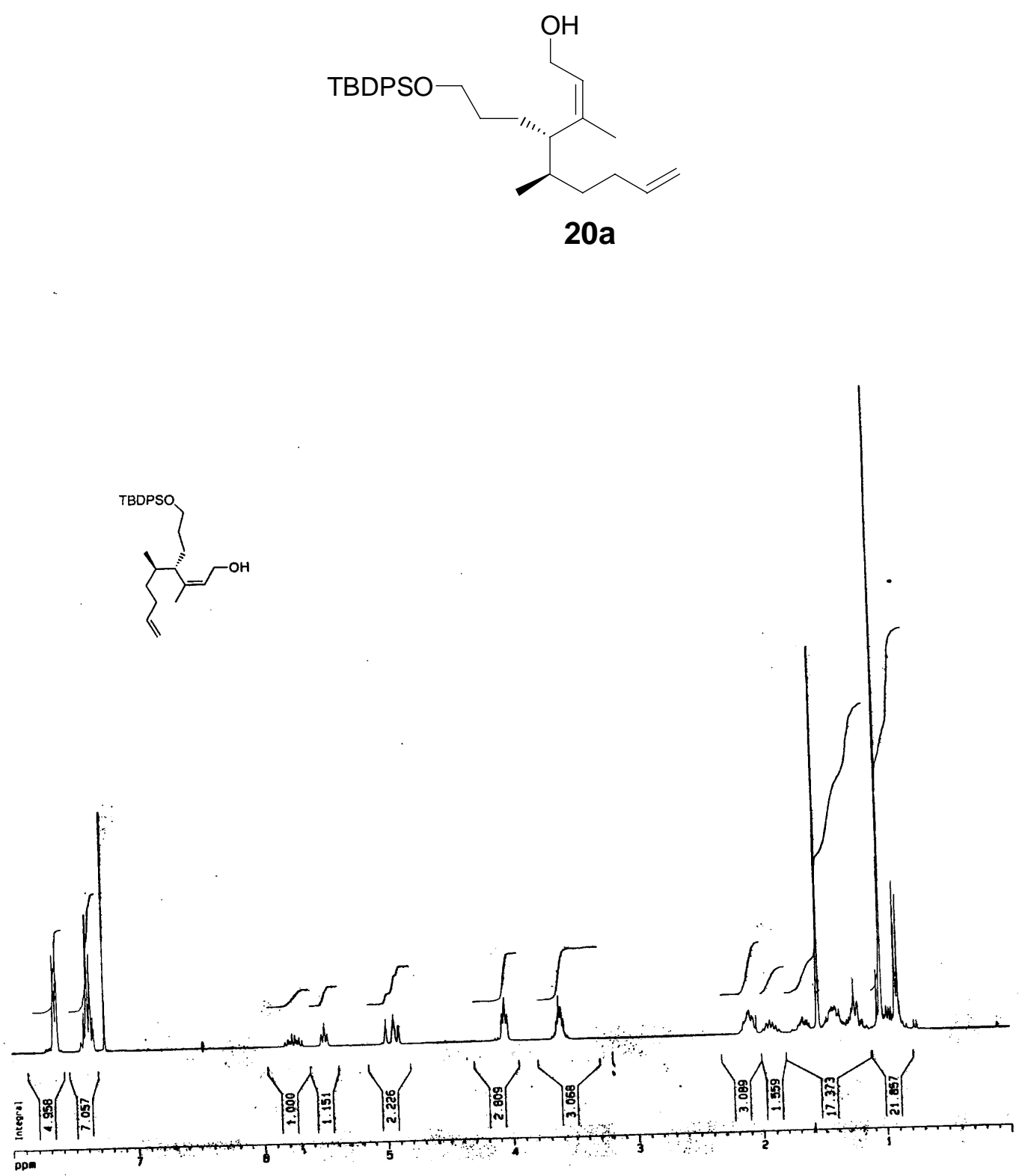


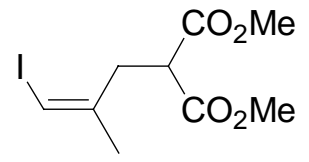

6

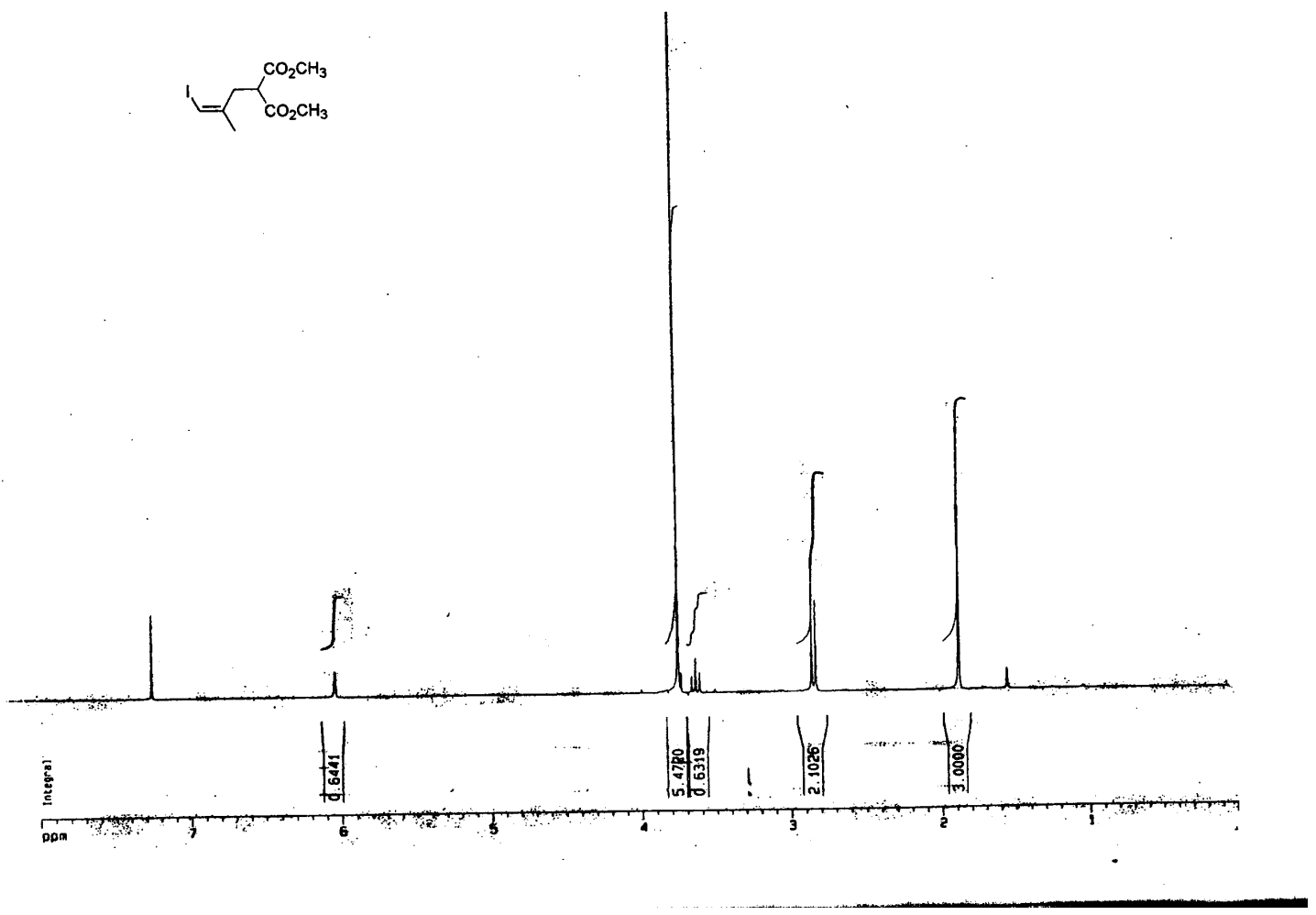



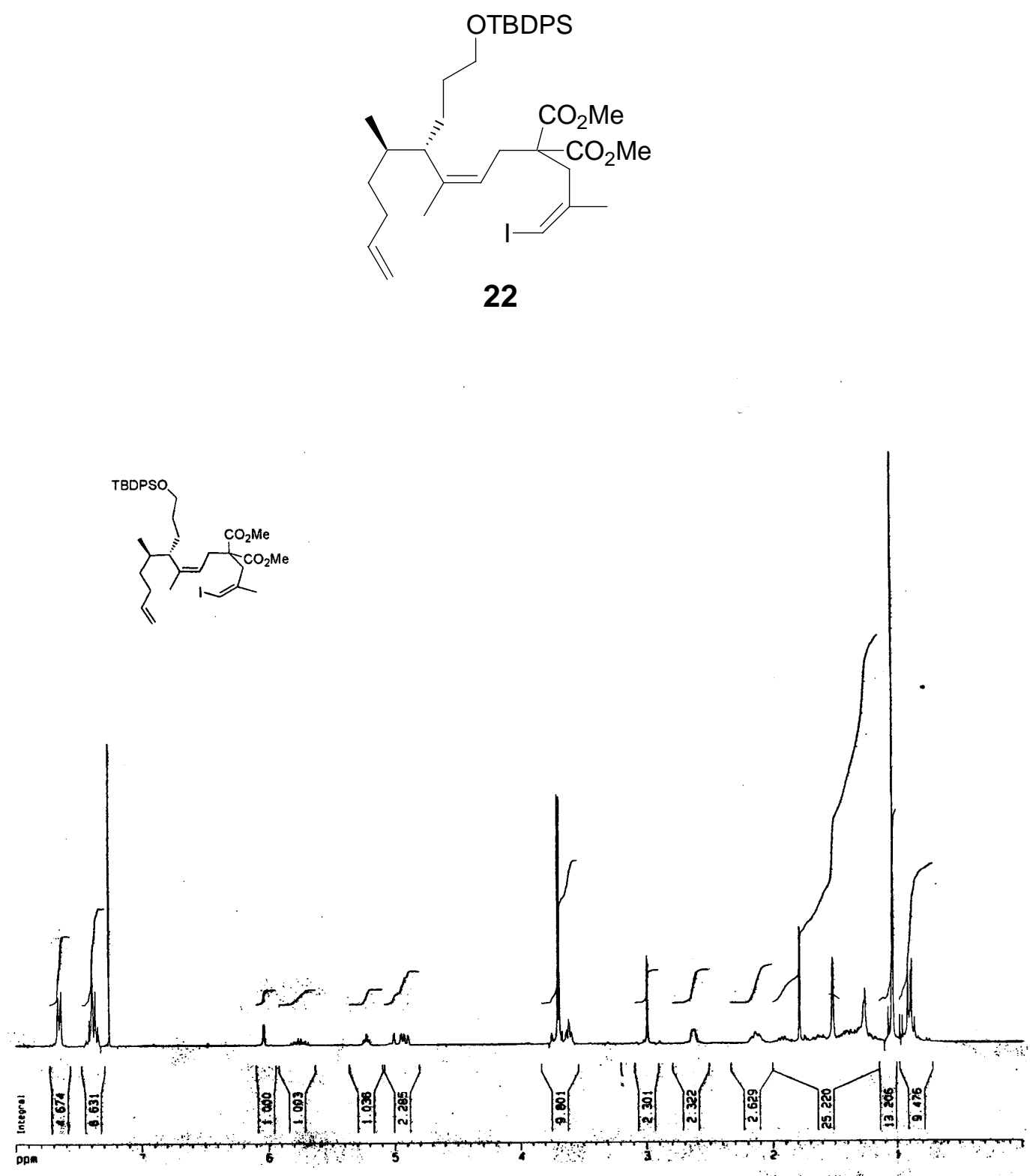


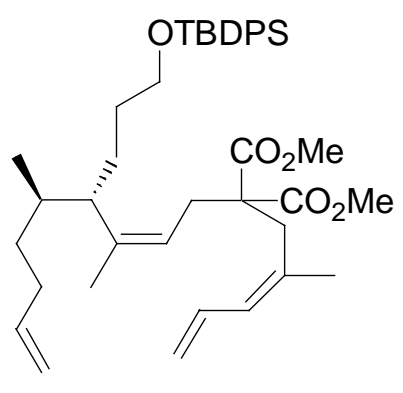

23

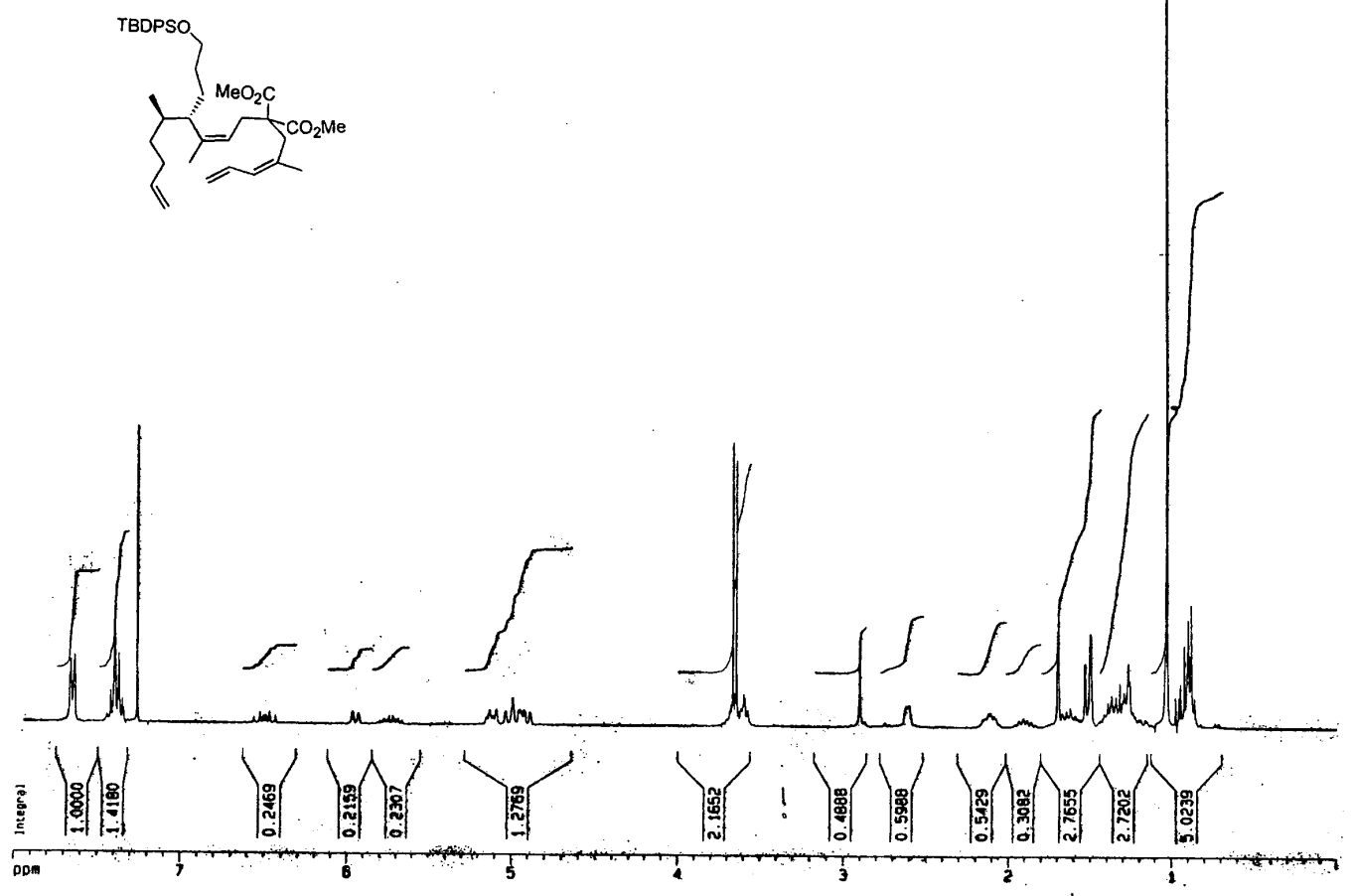




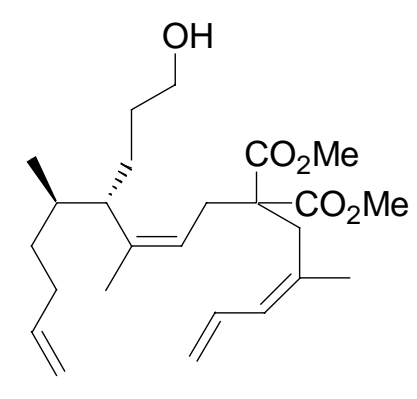

\section{3a}

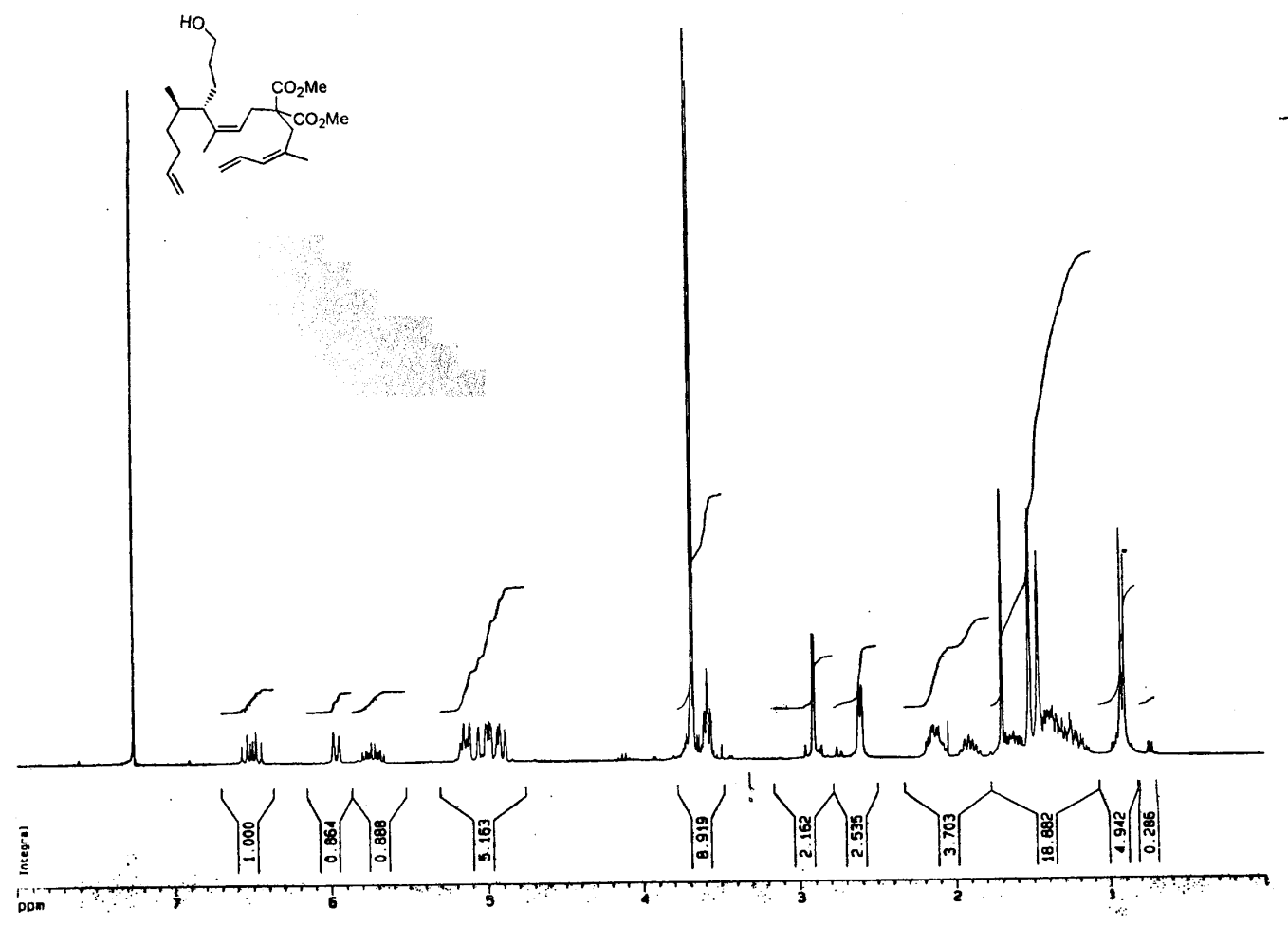




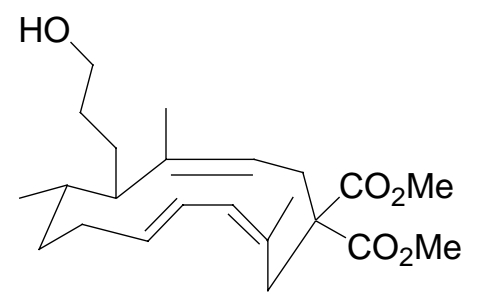

24

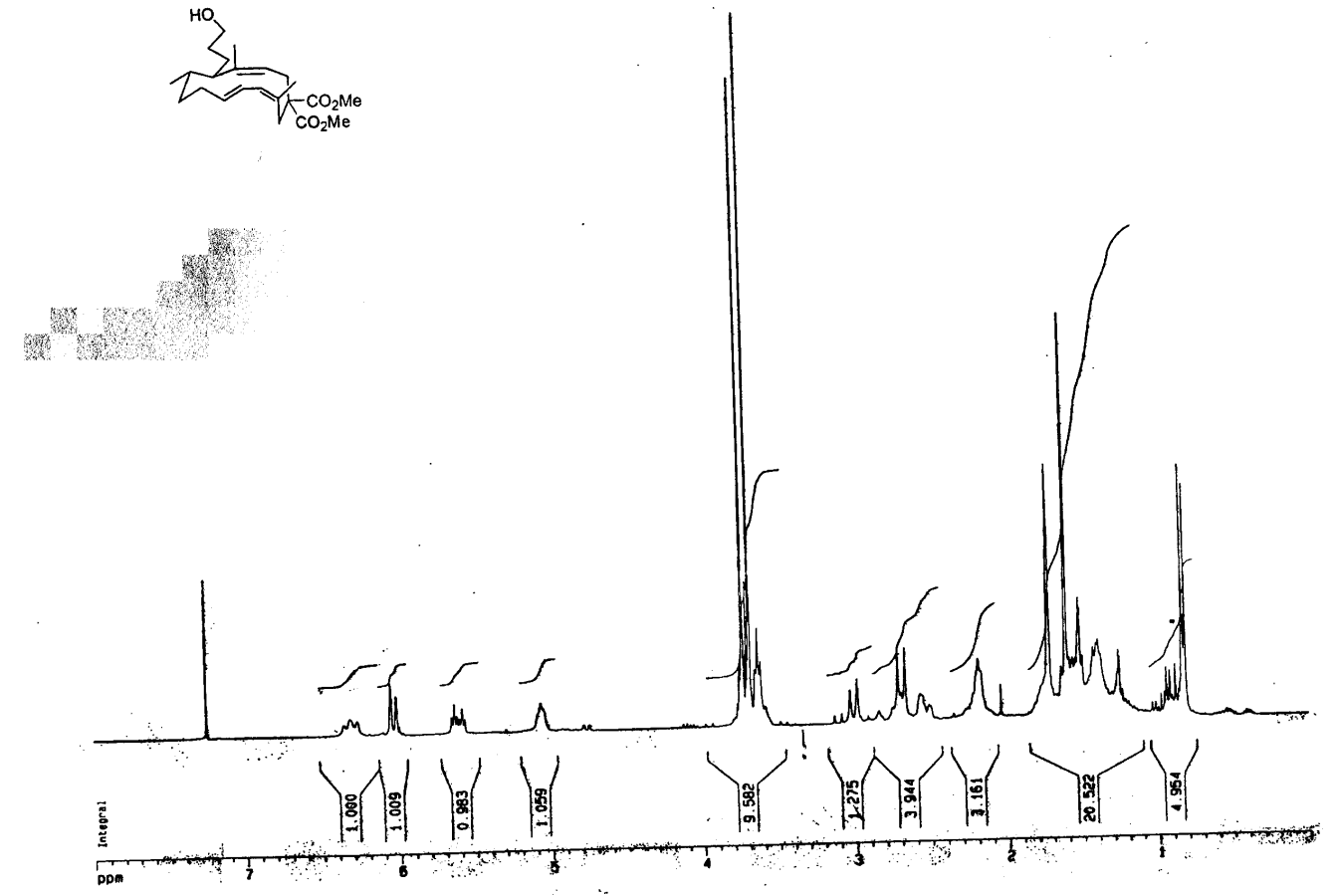



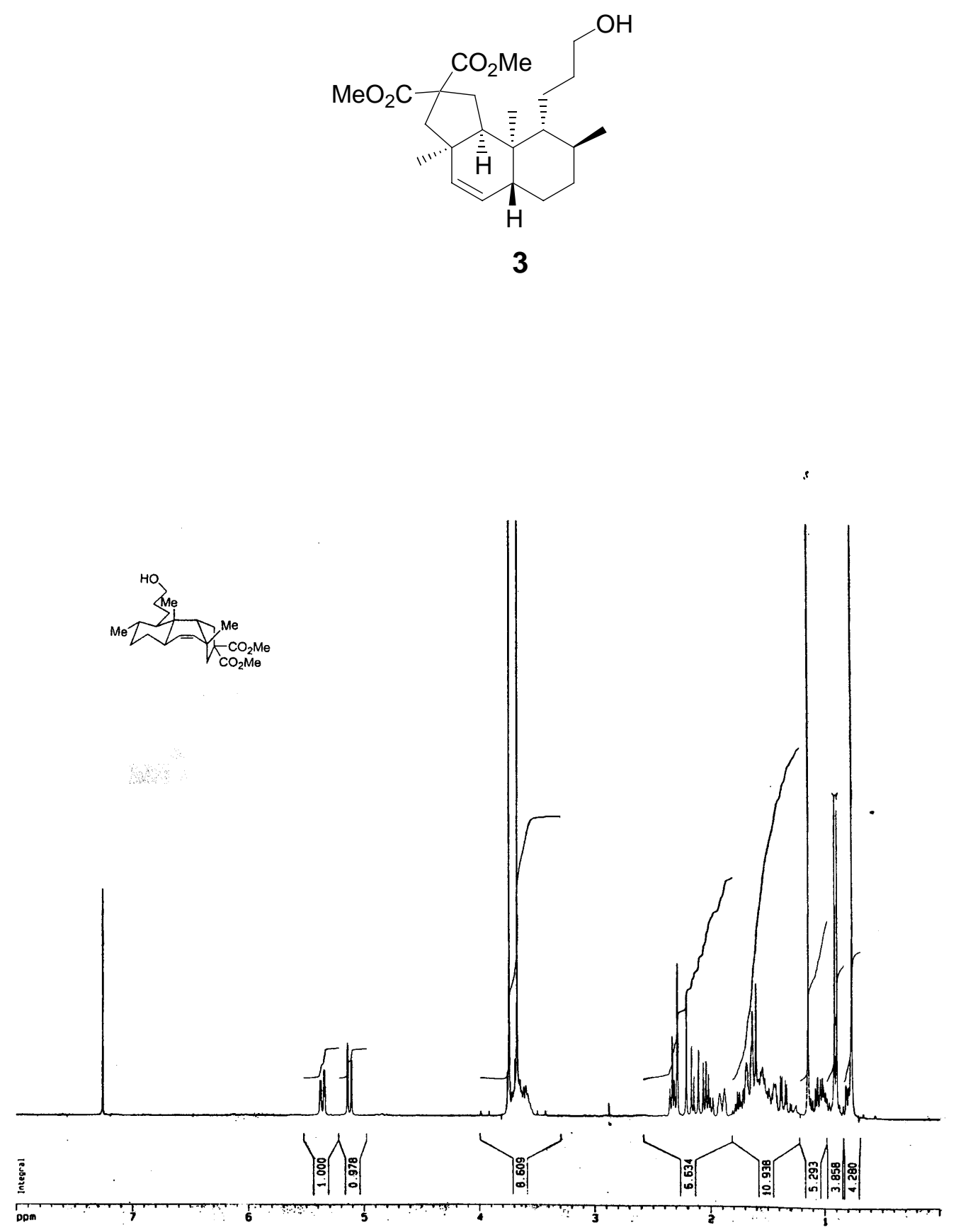


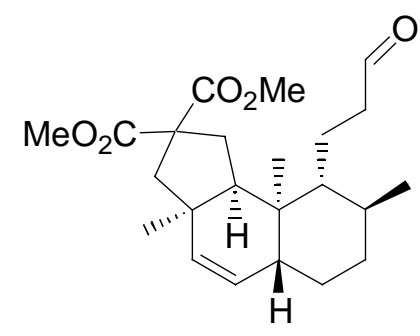

3a

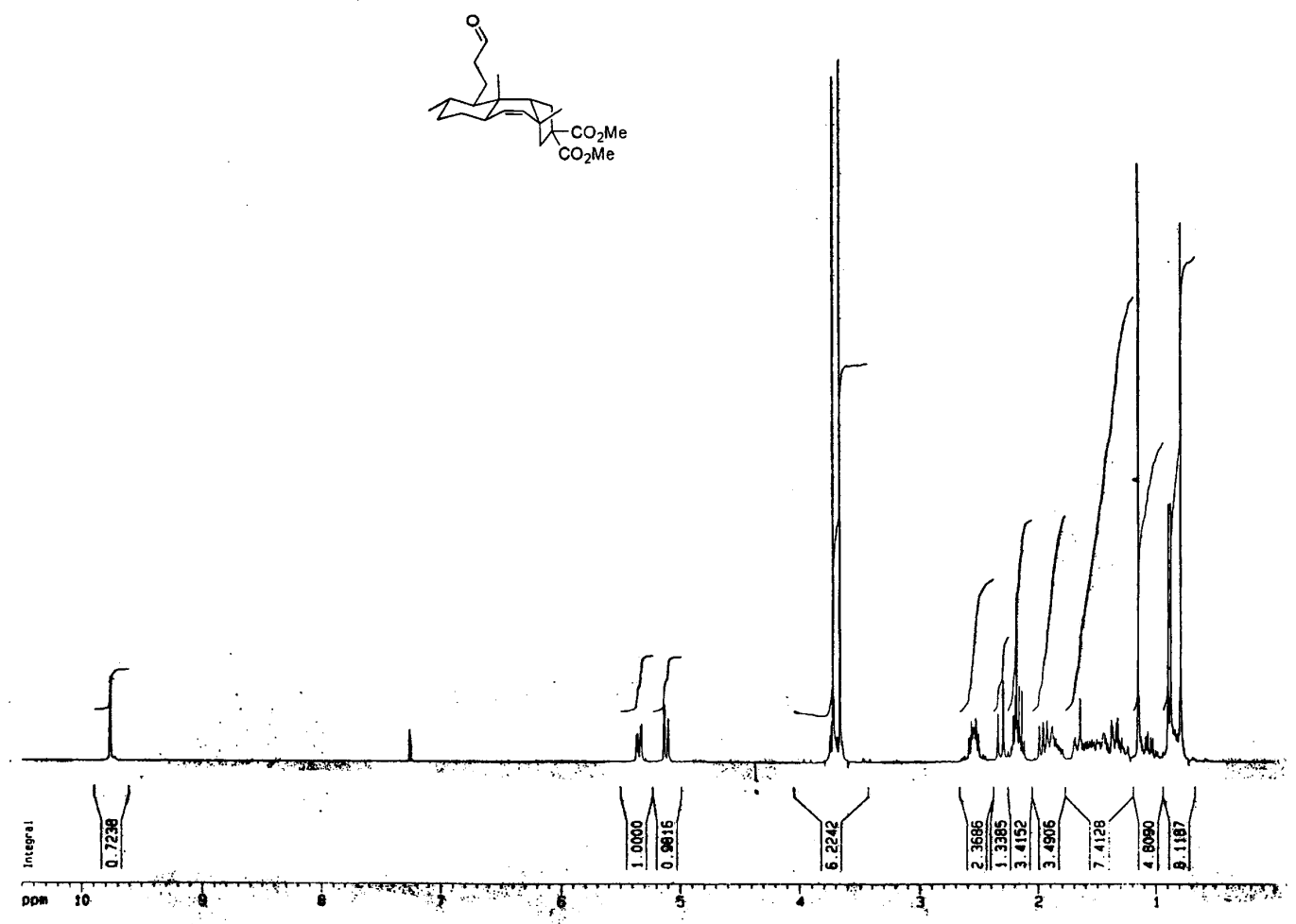




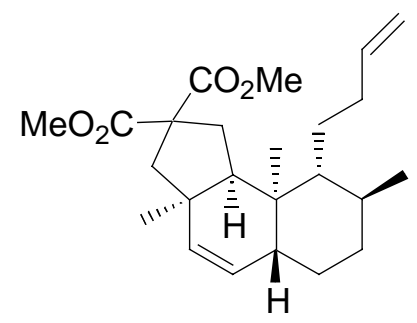

25

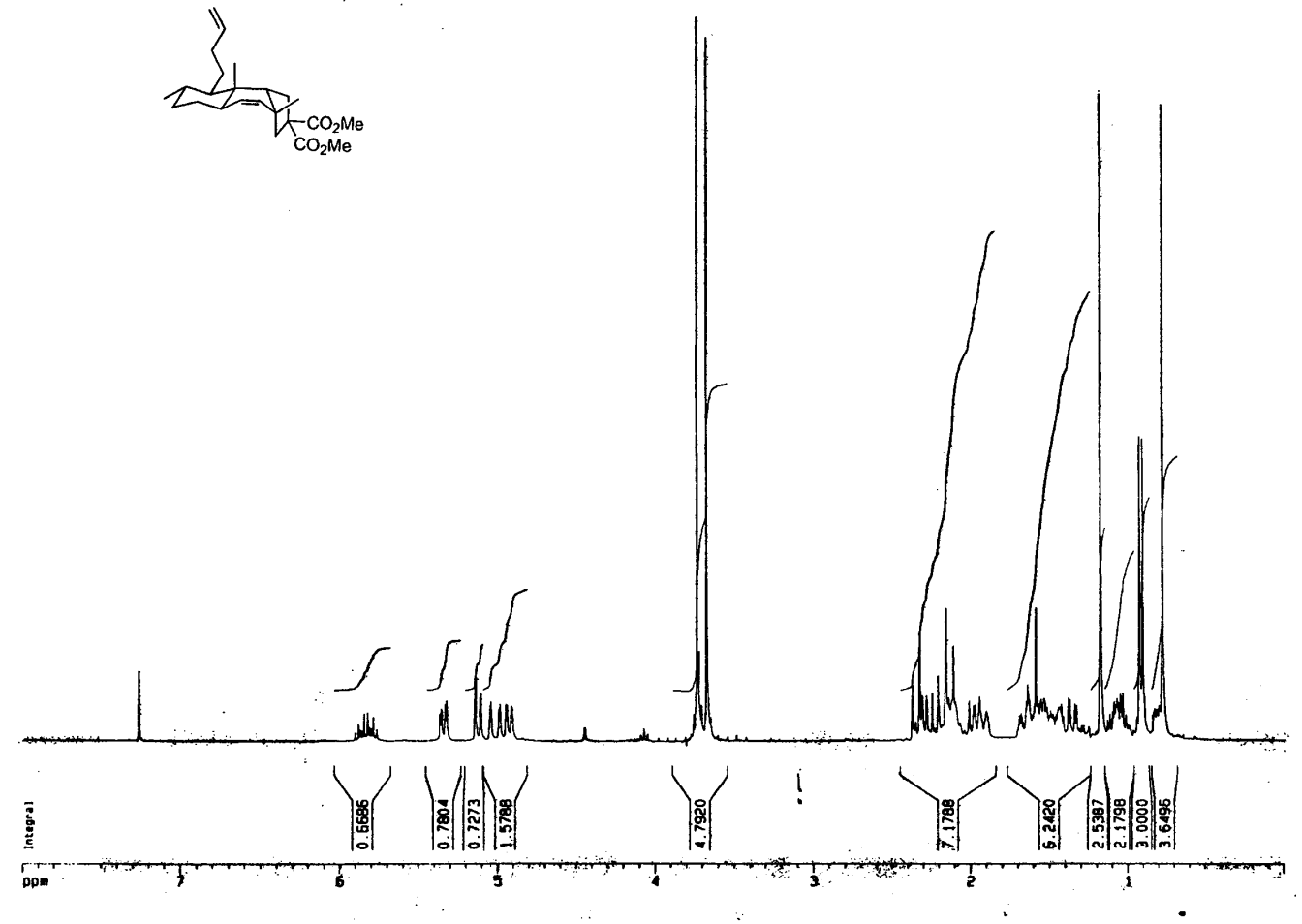




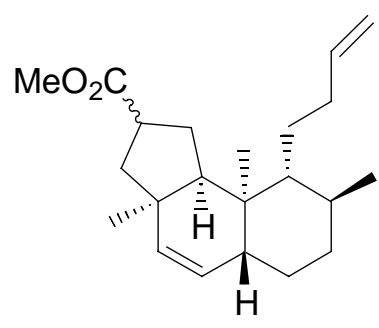

26

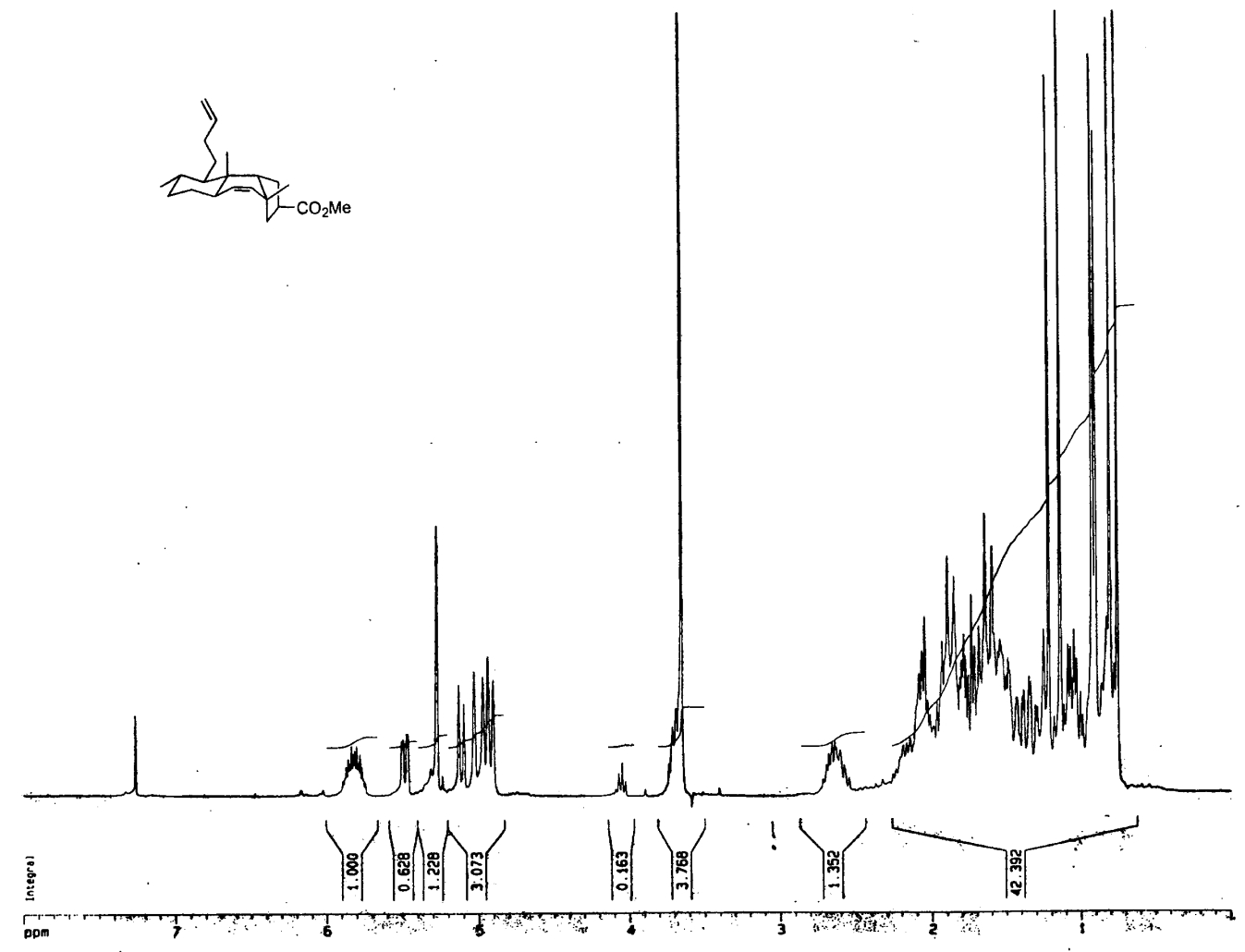




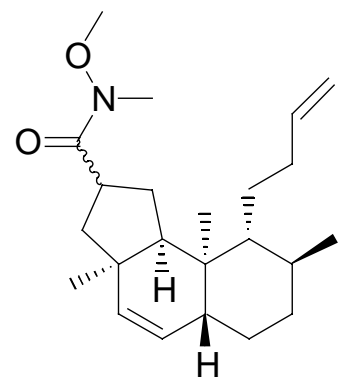

27

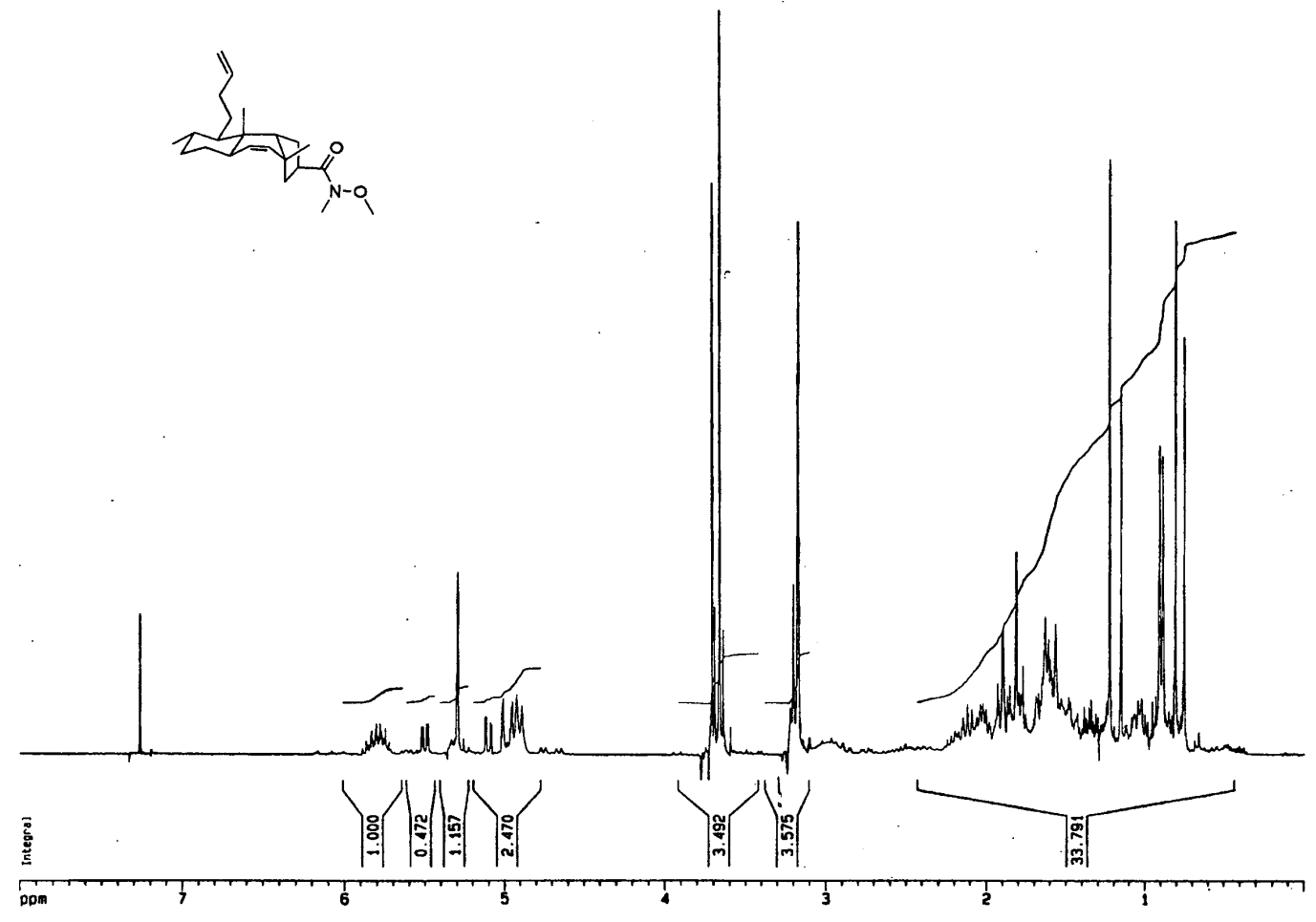




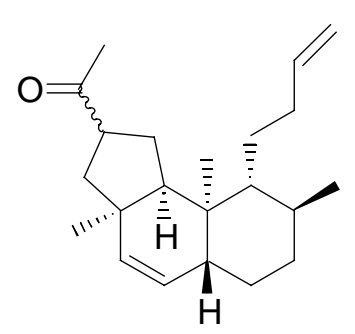

28

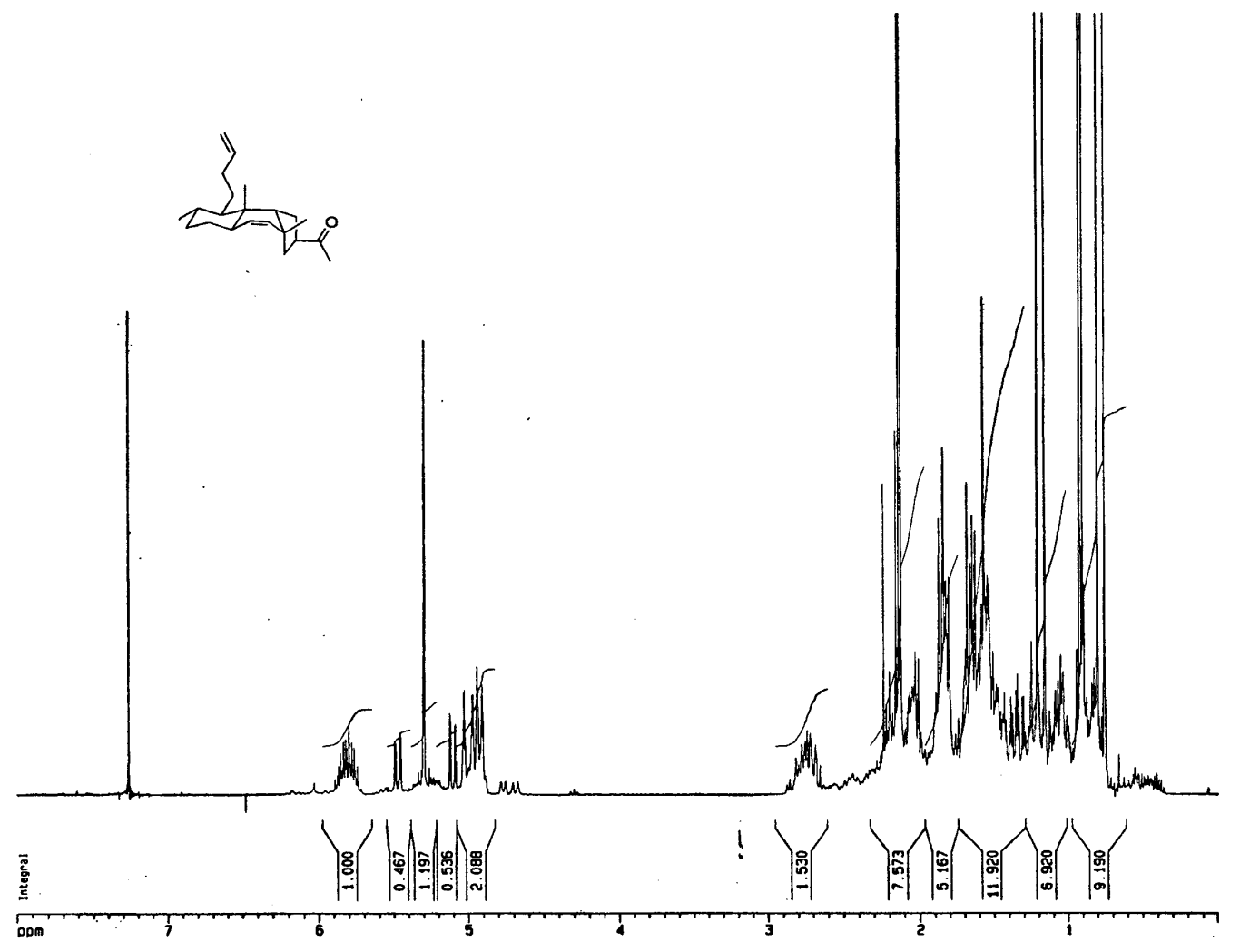



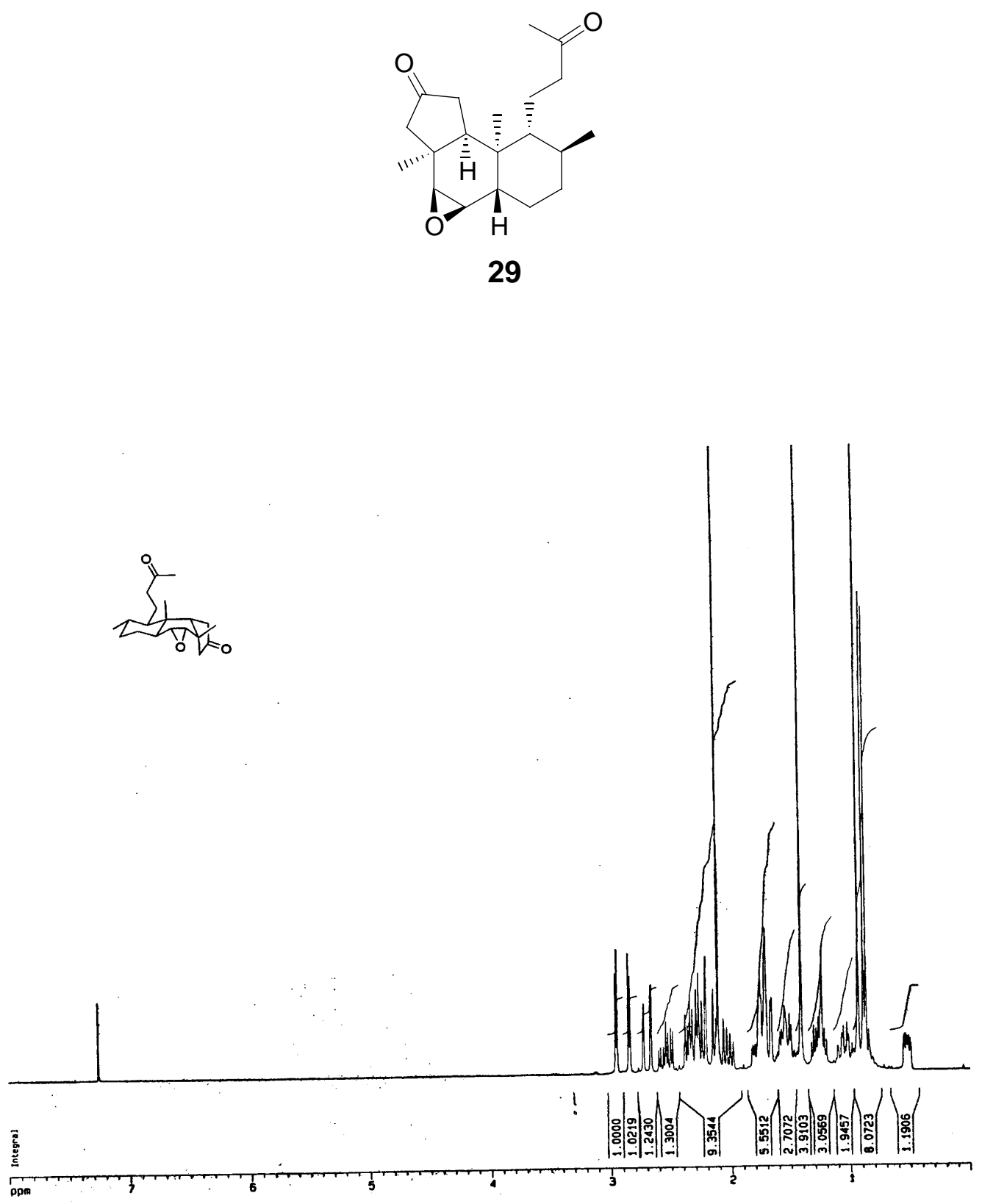


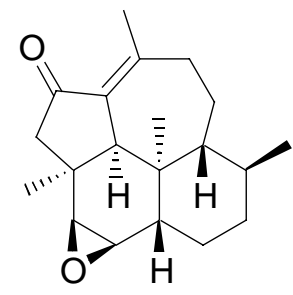

30

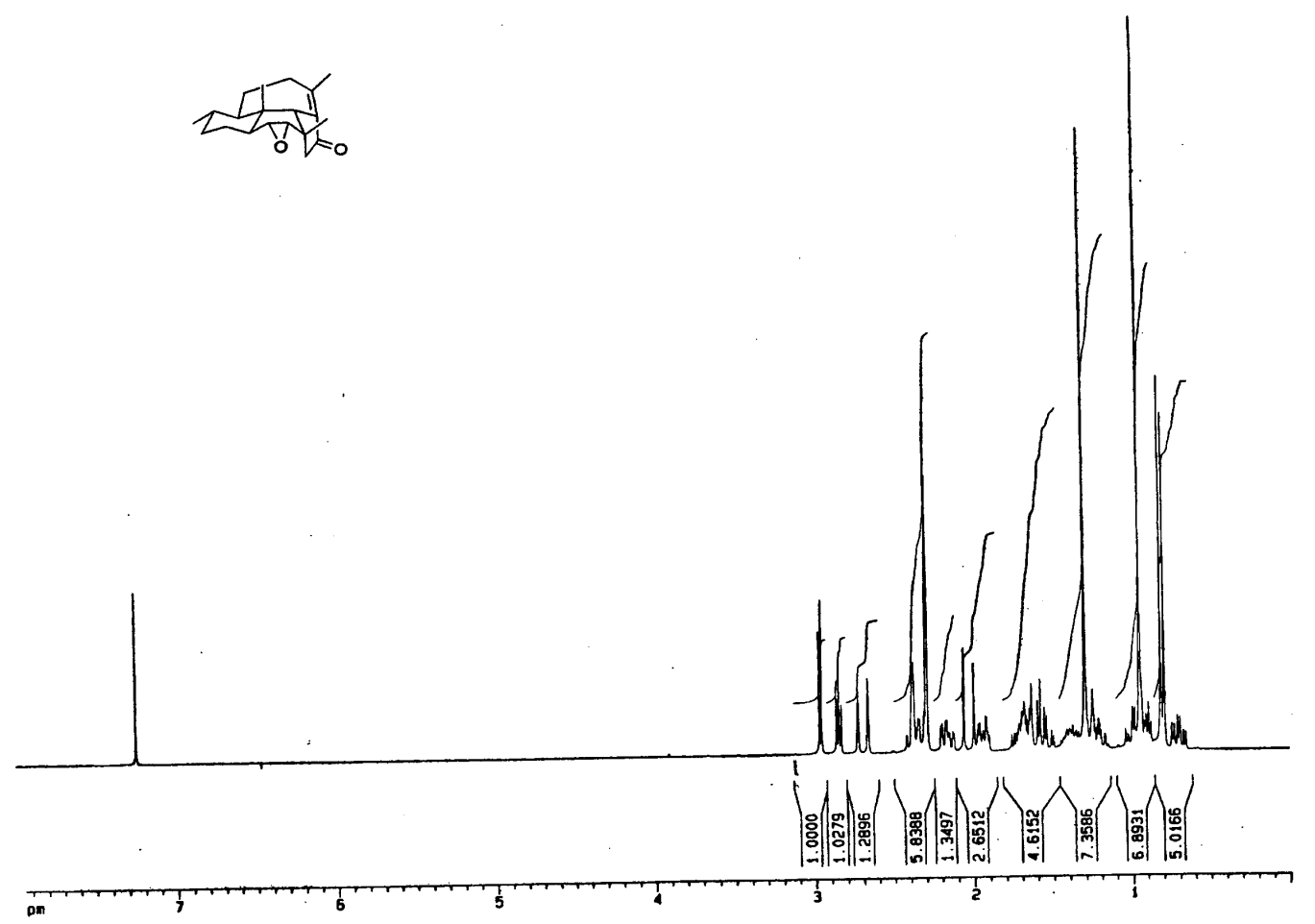




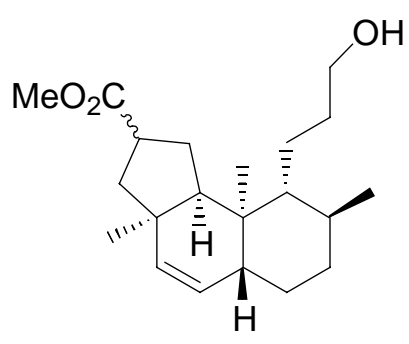

31

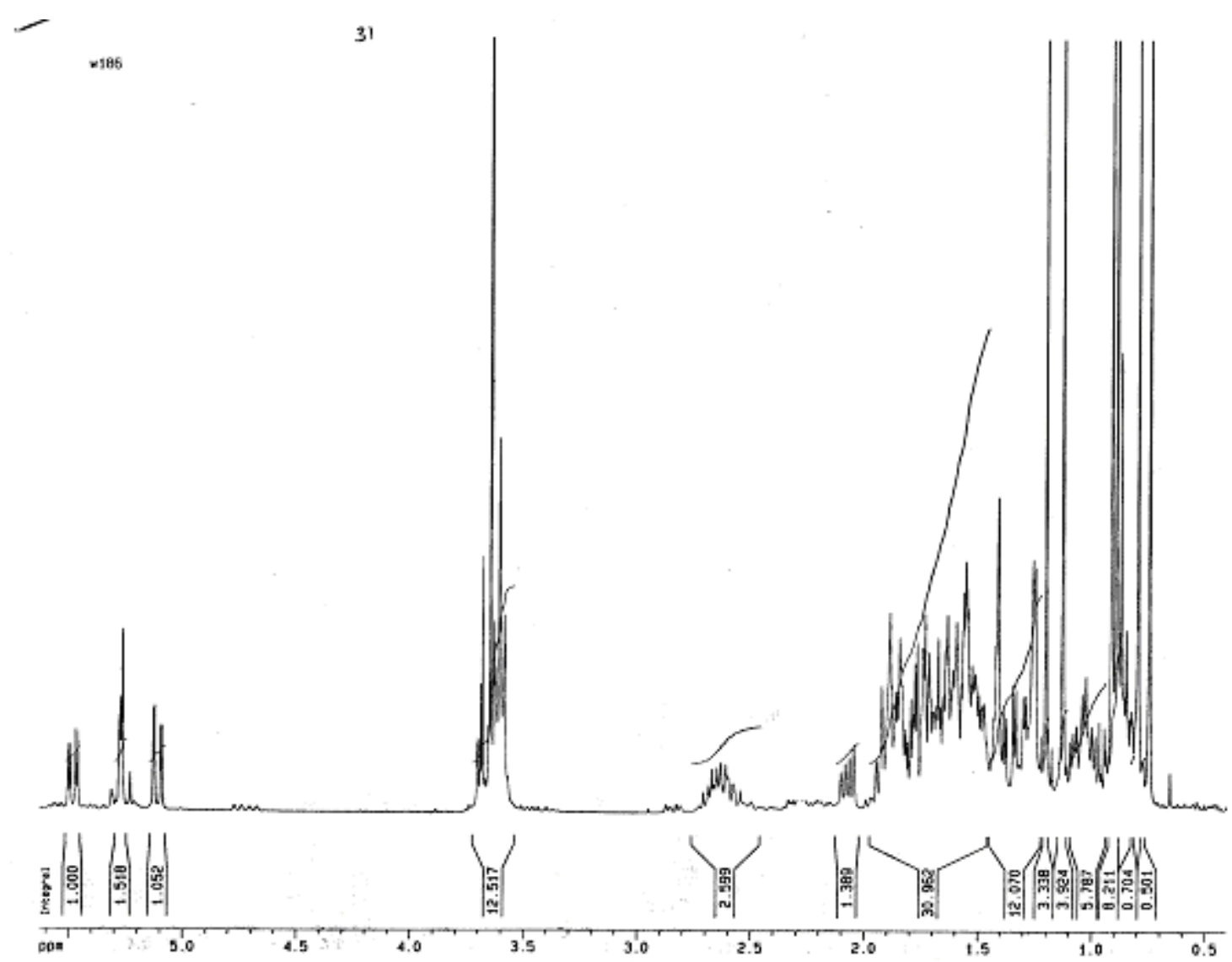



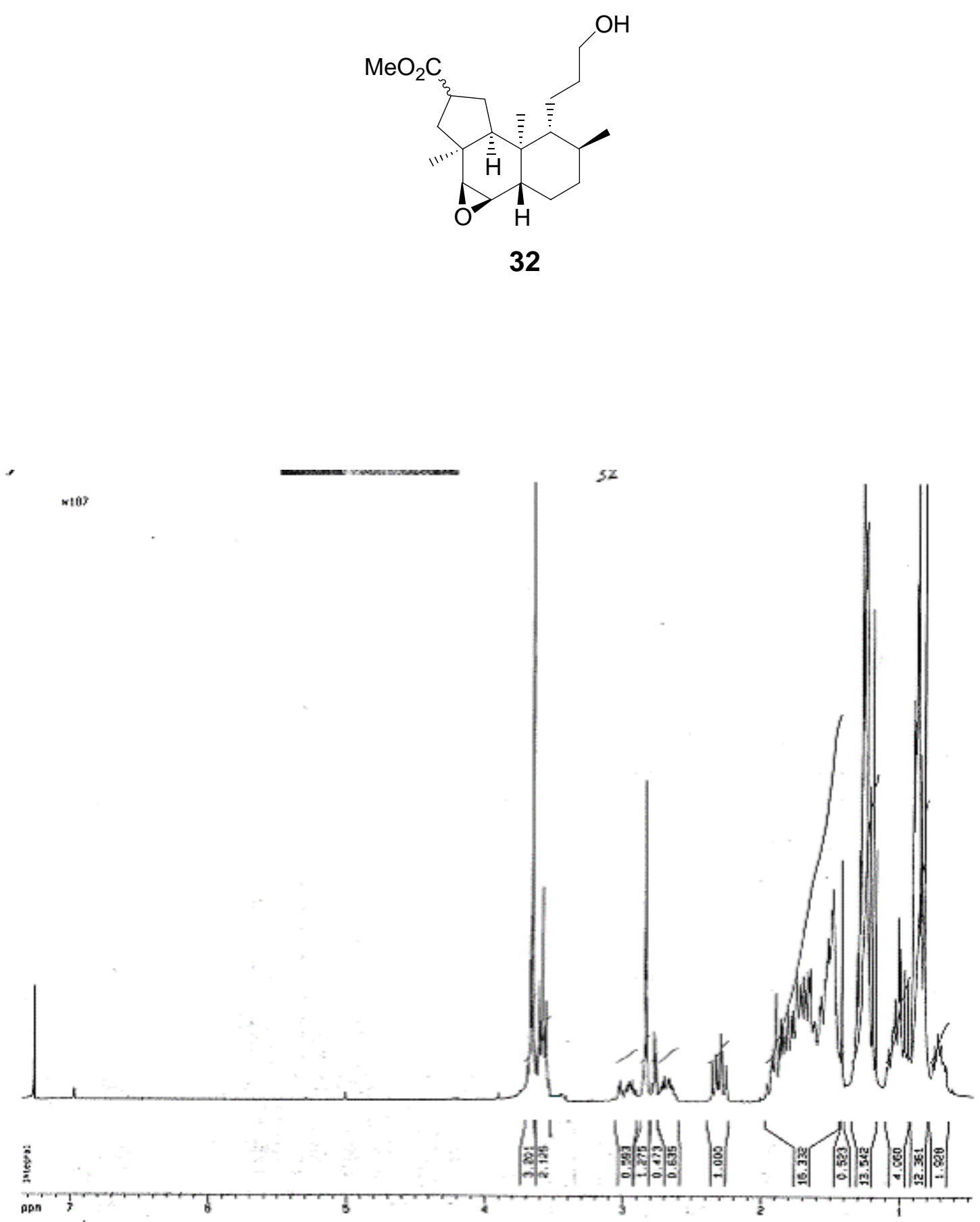


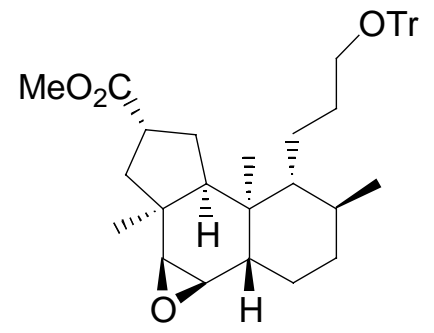

33

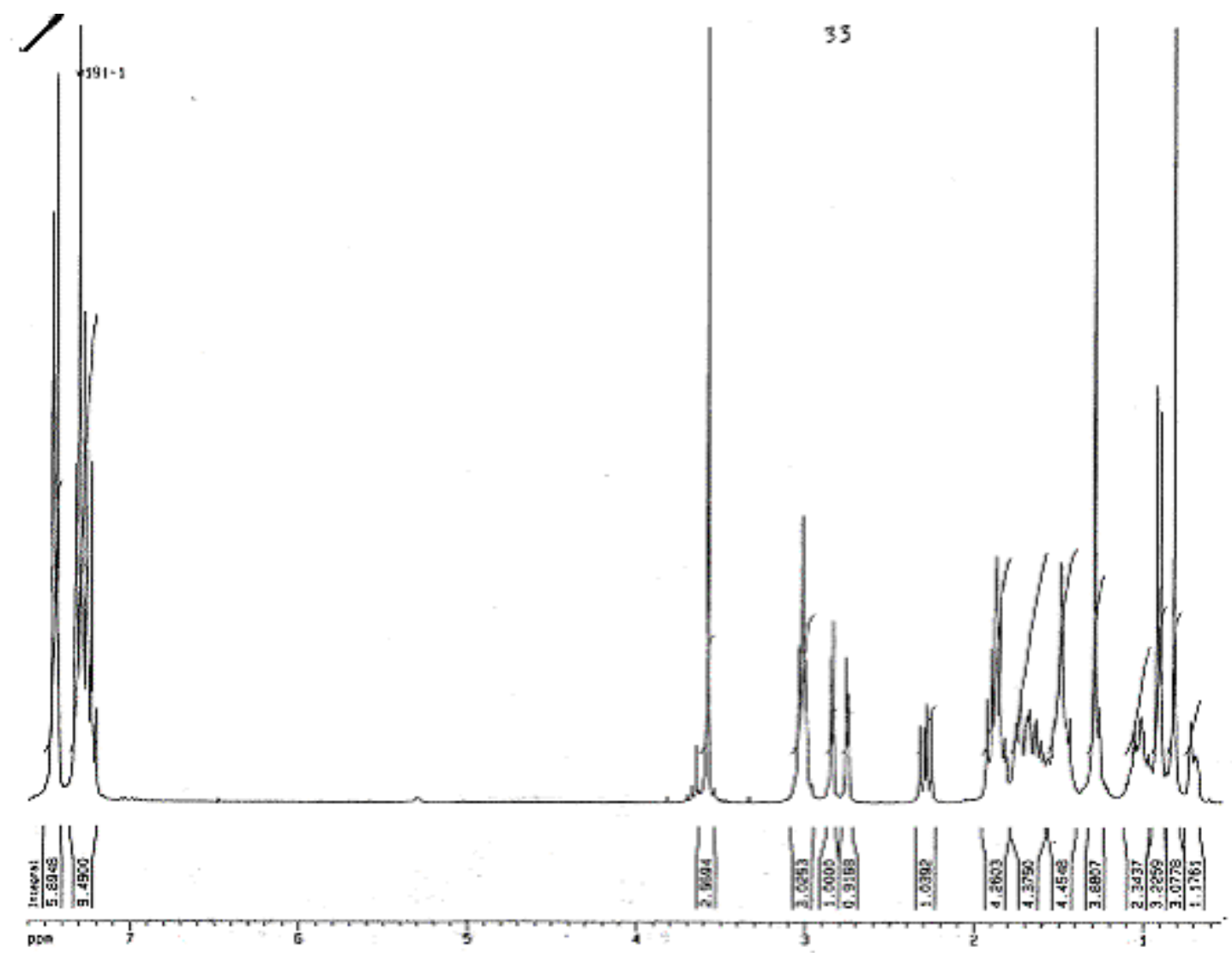



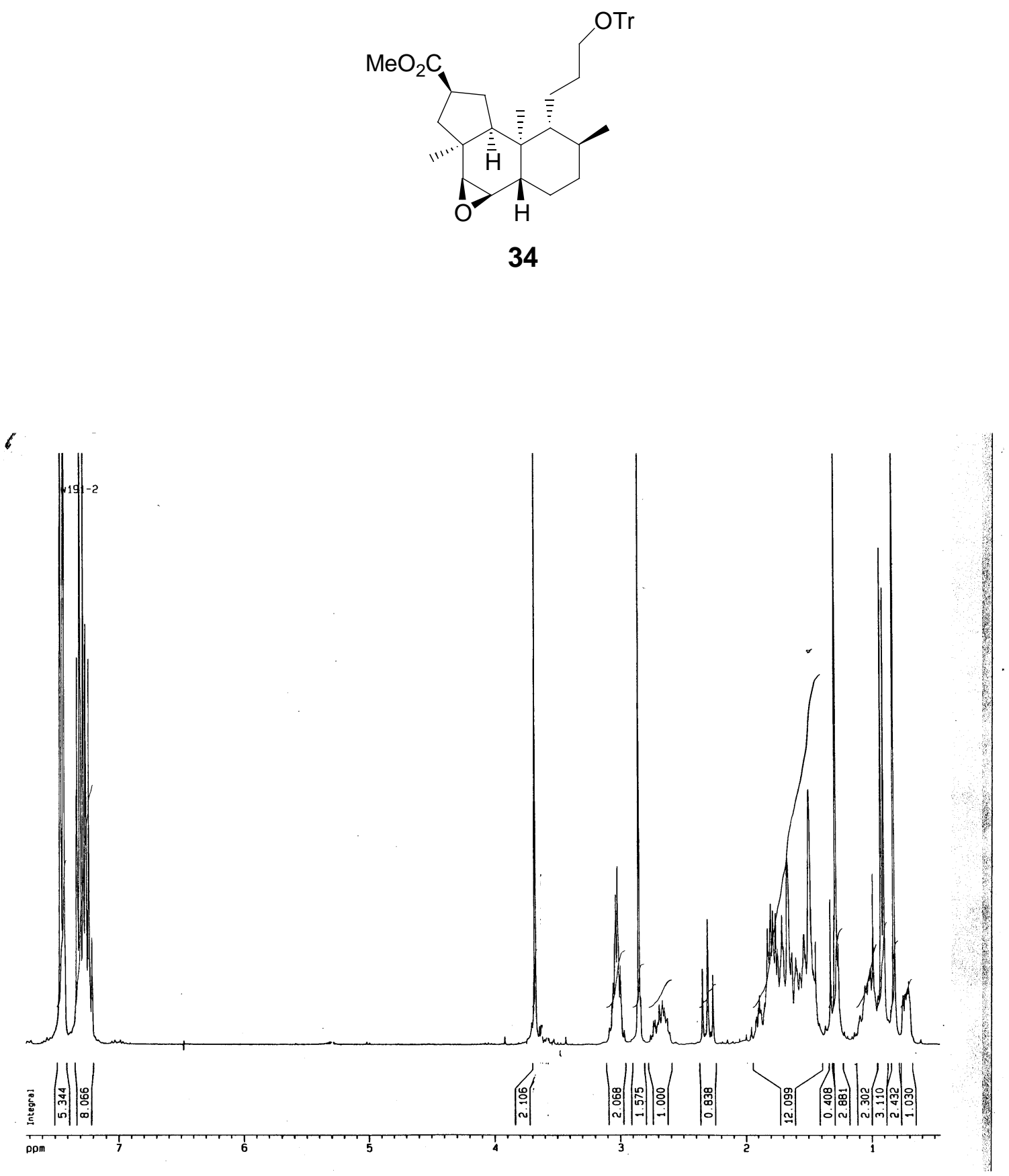


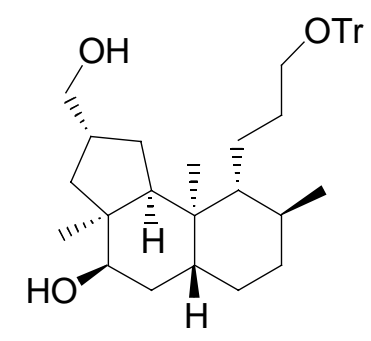

35

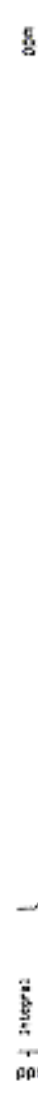

5 蛋

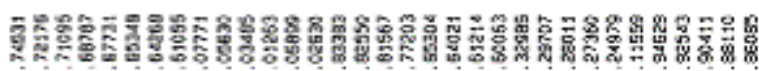
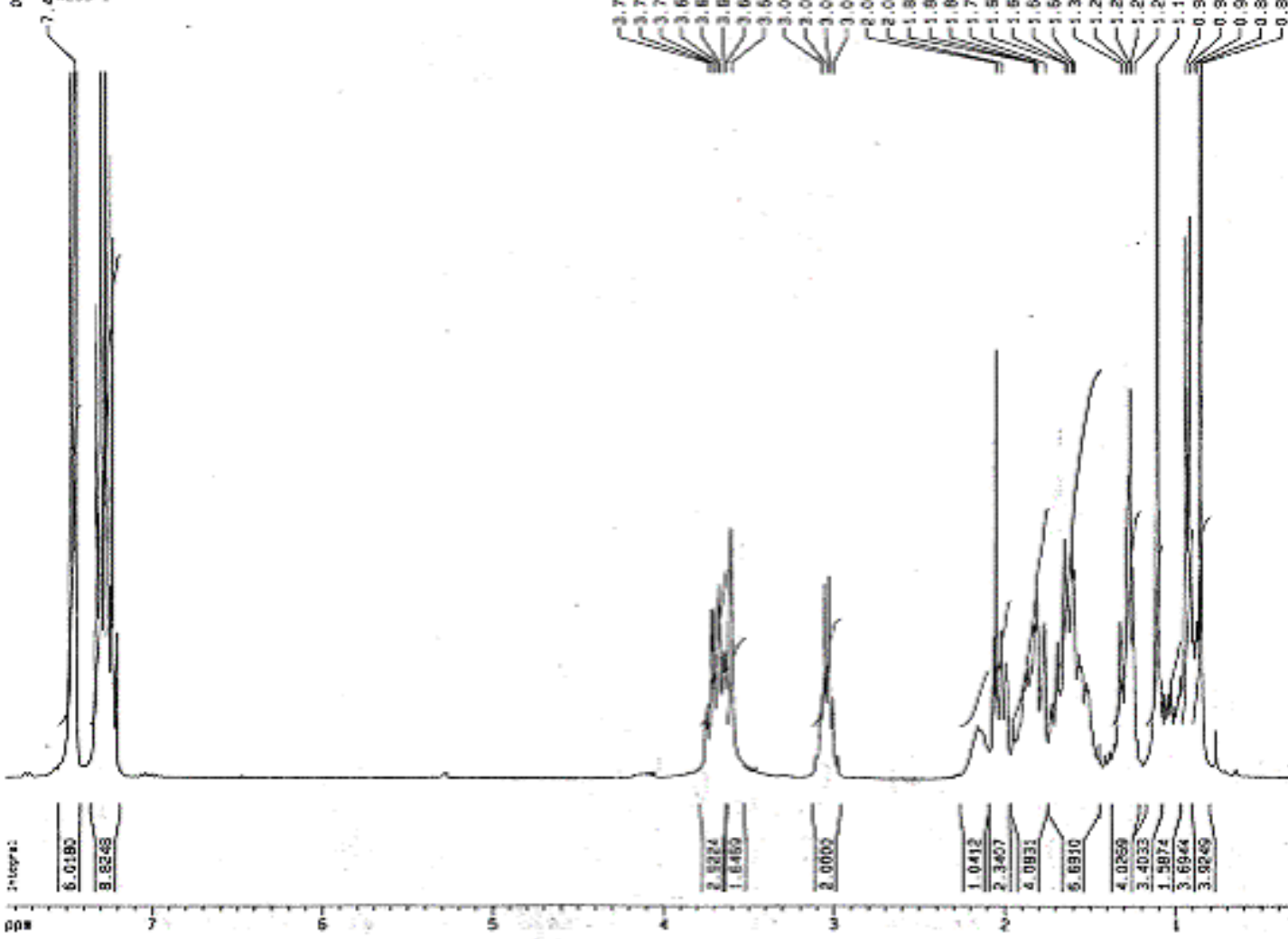


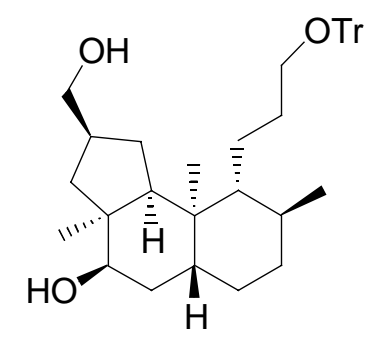

36

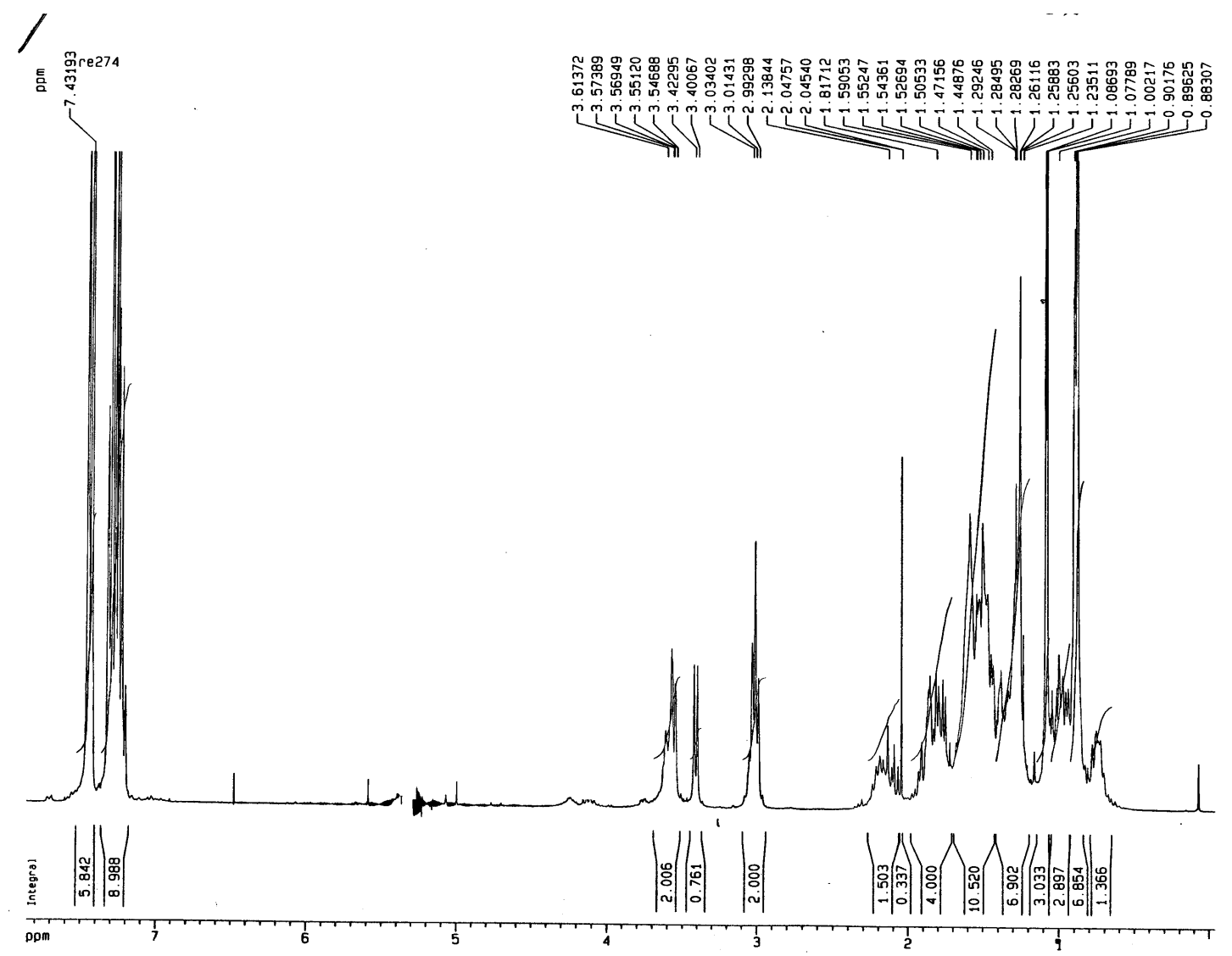



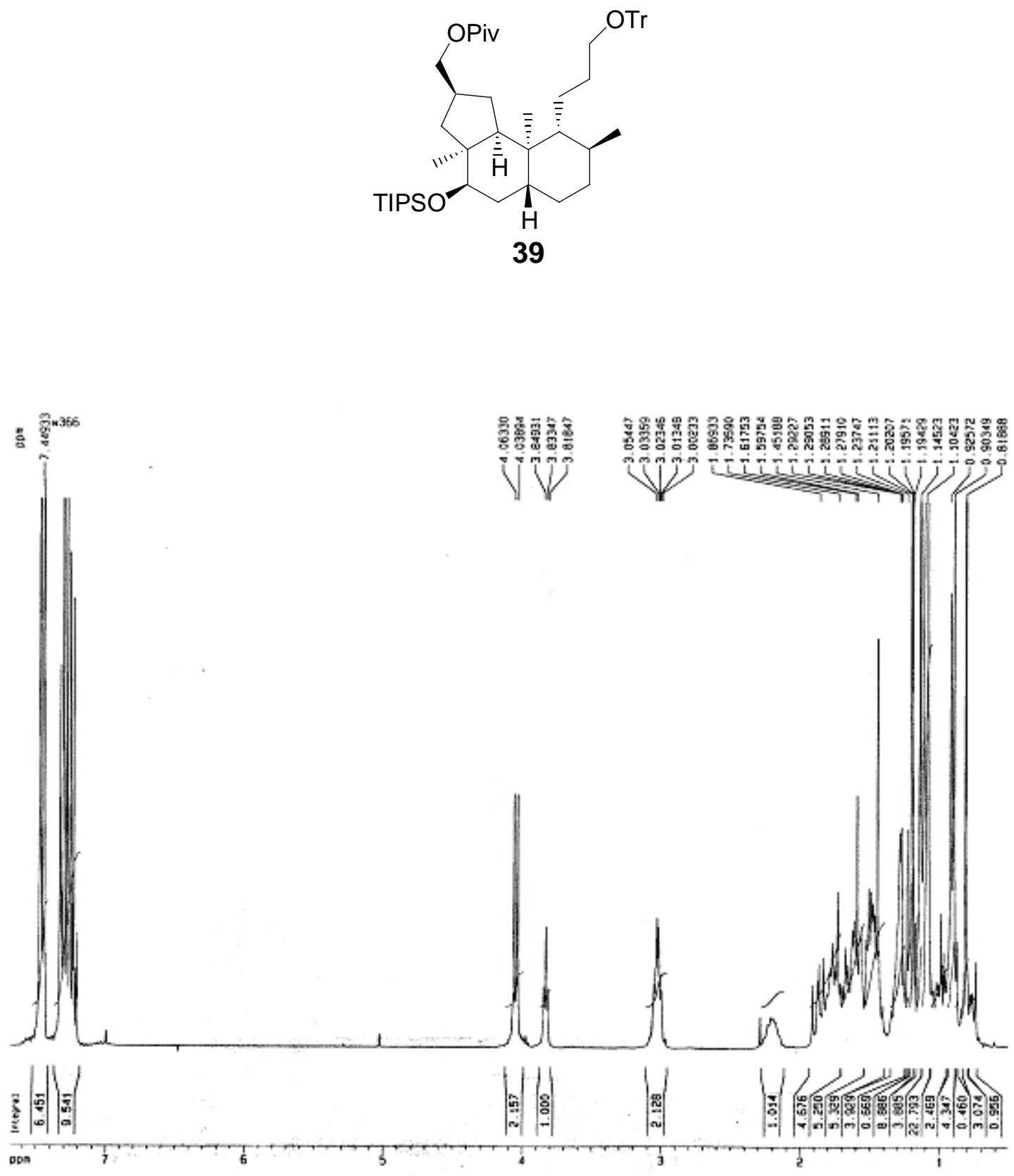

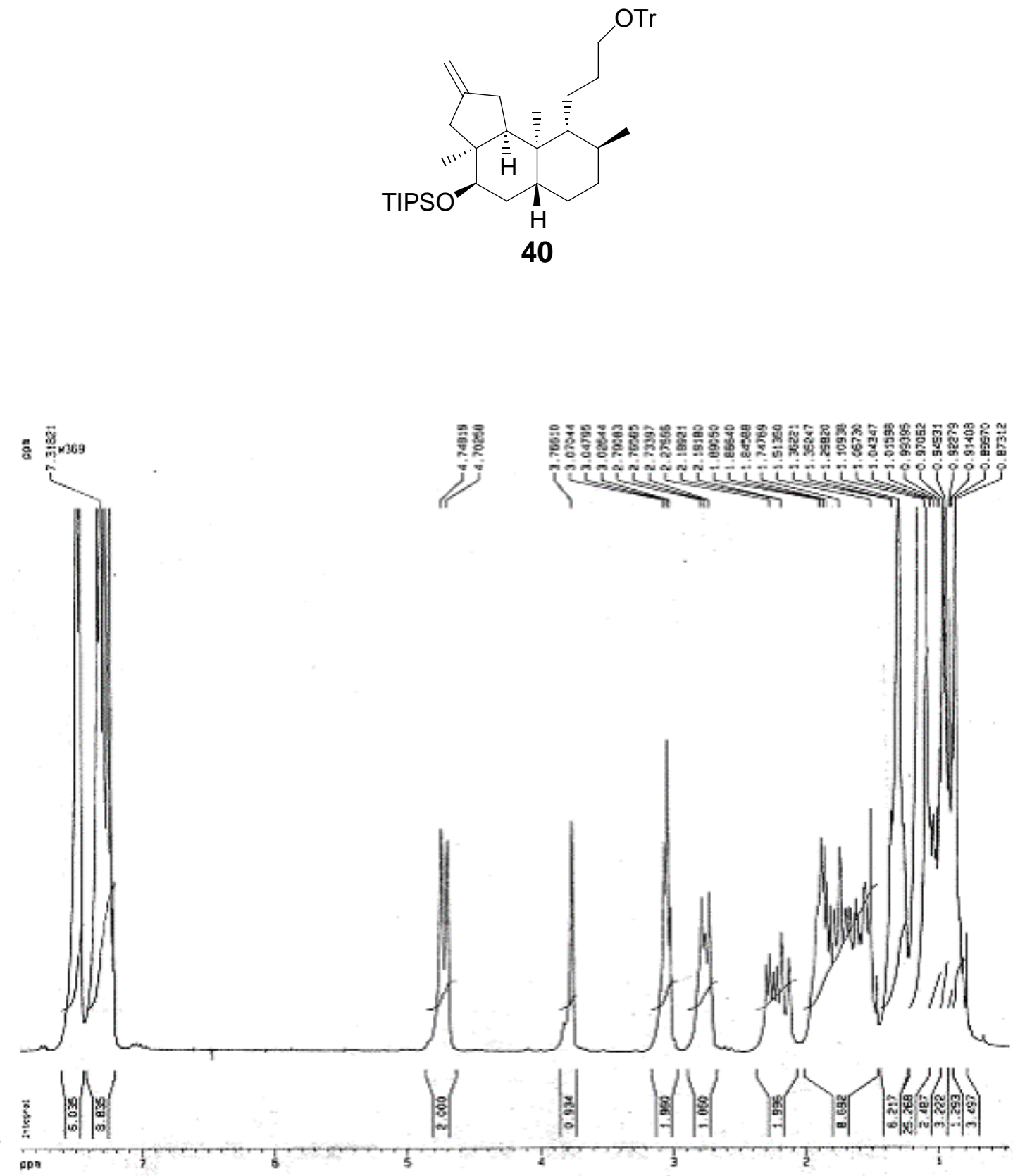


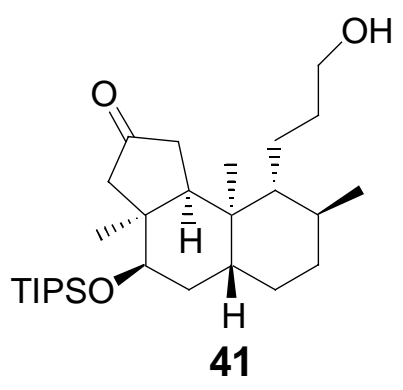

'

j

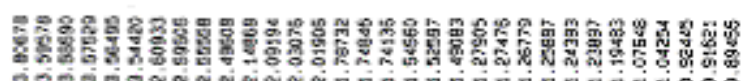

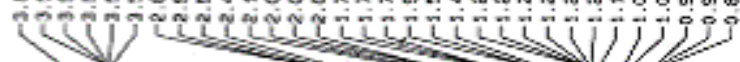

I 1 का का का

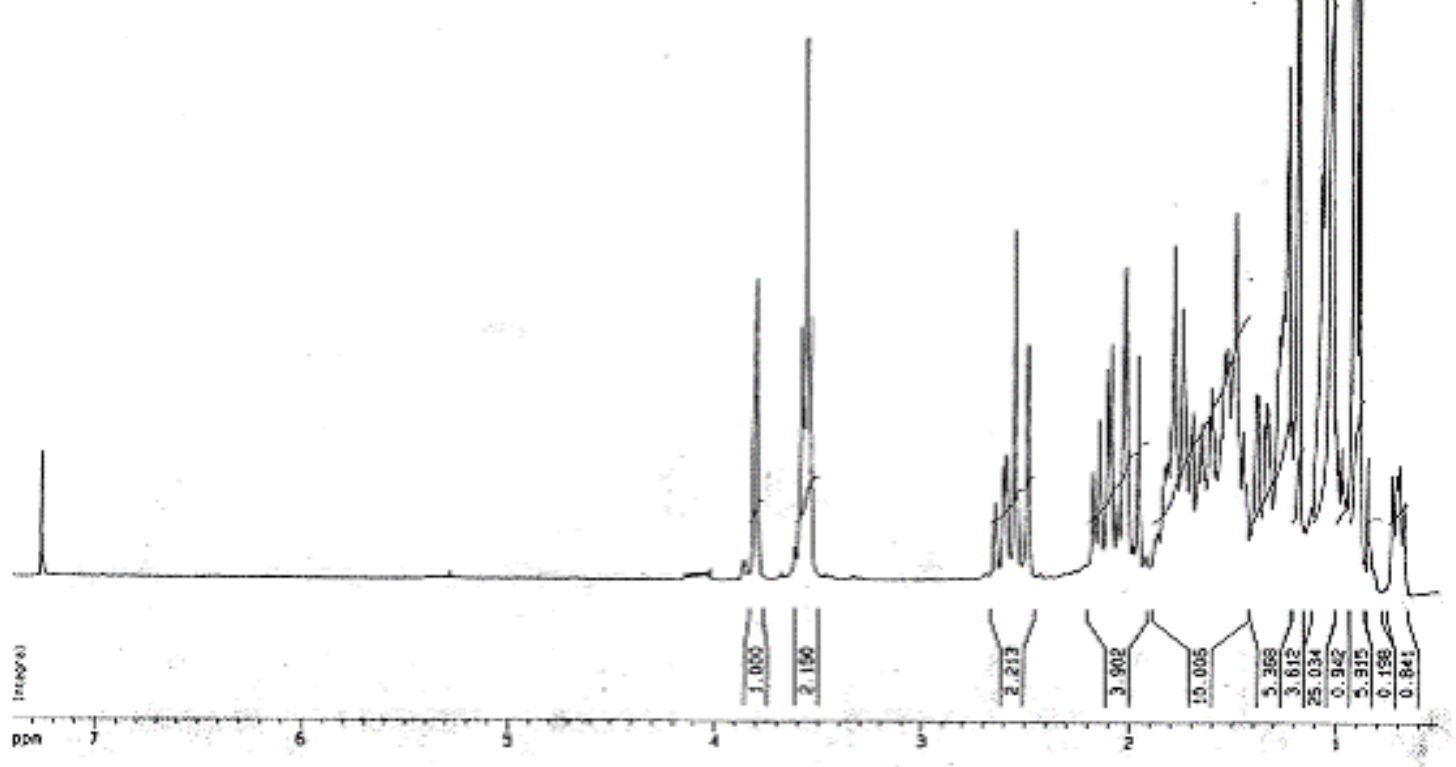



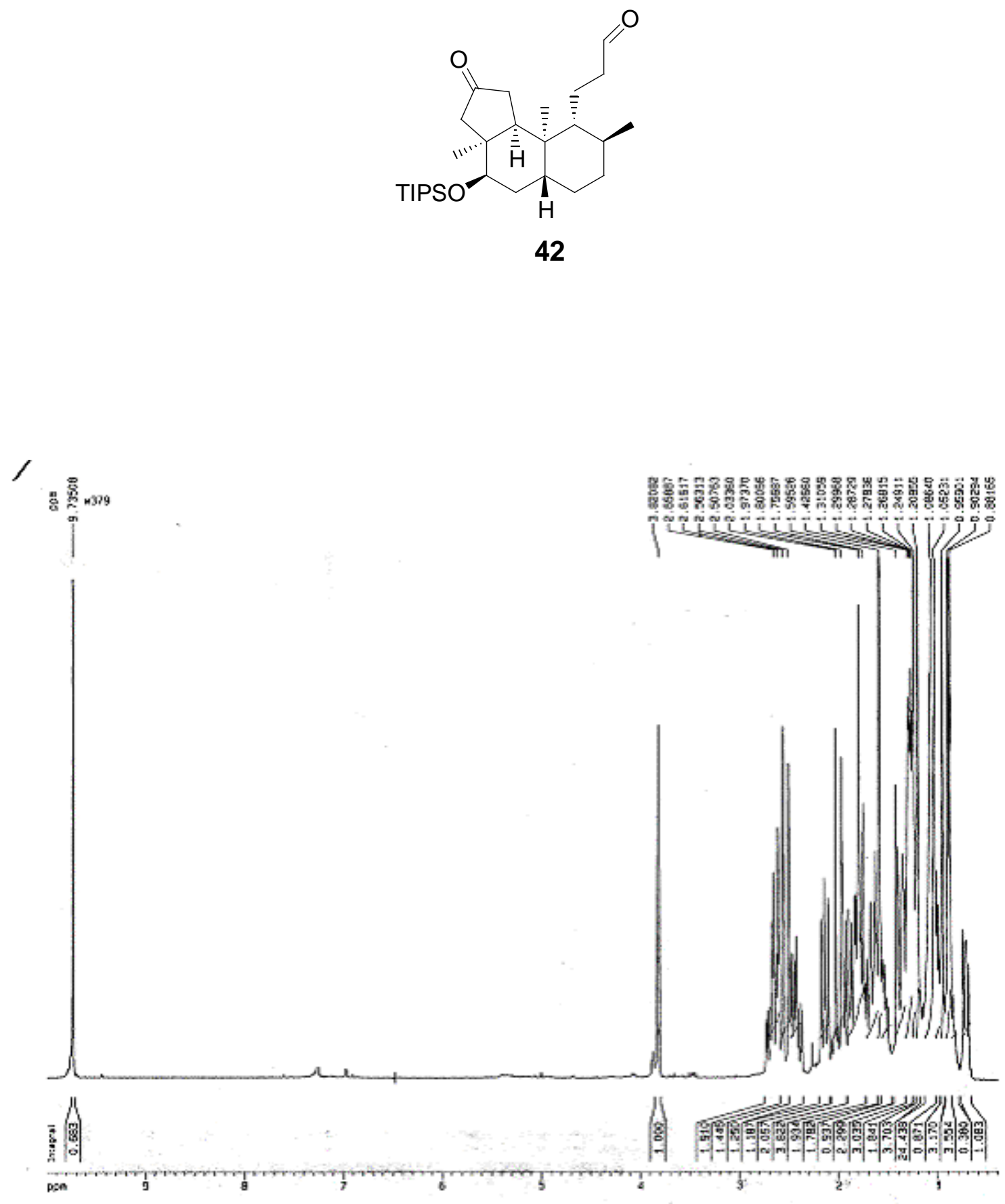


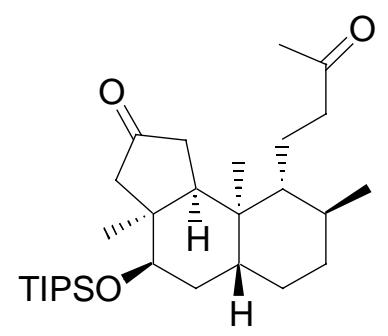

43

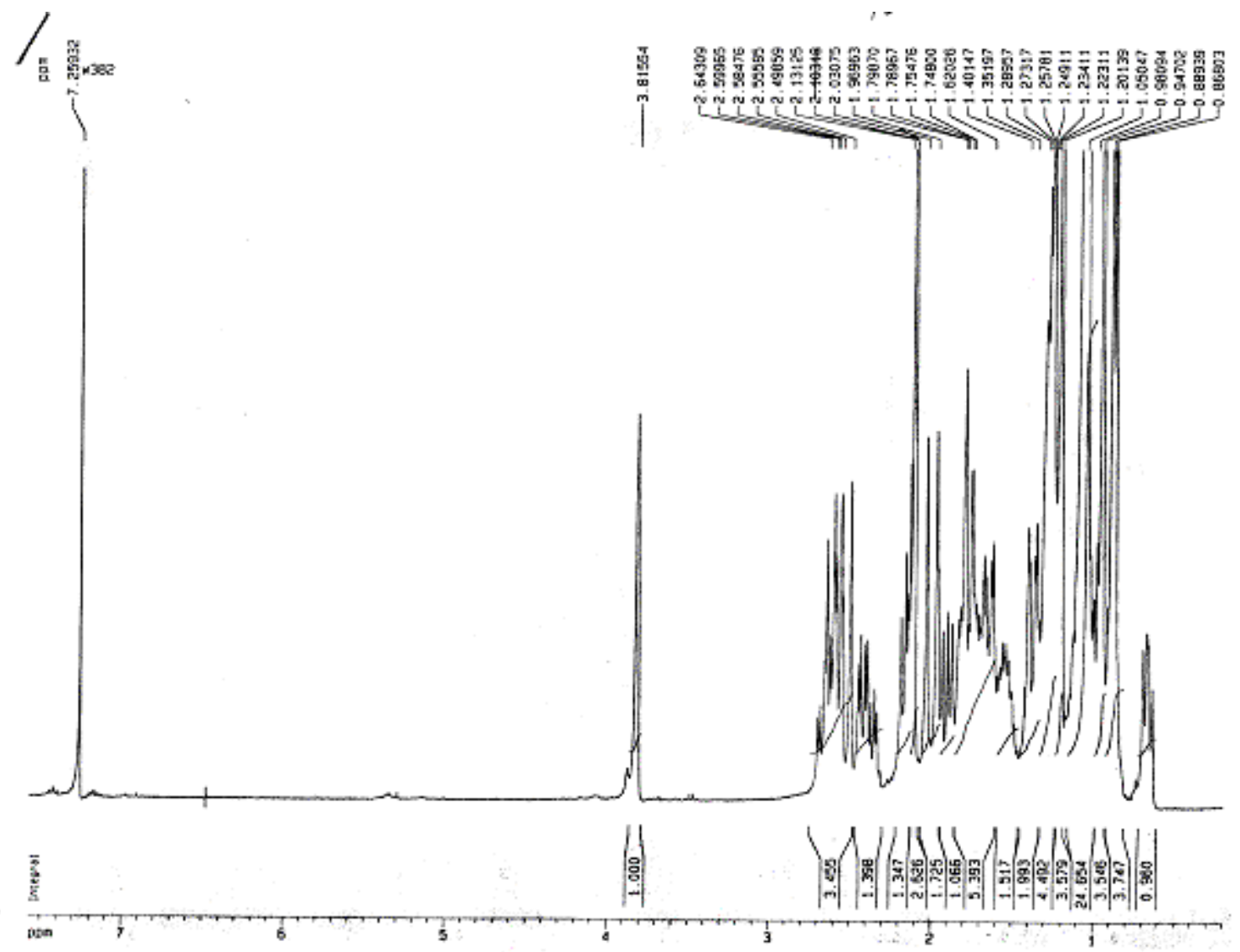




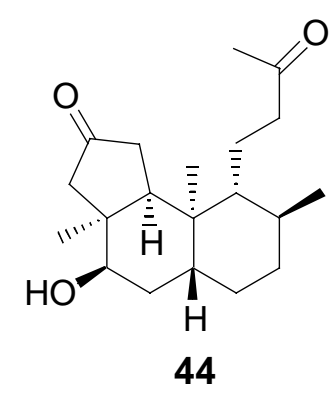

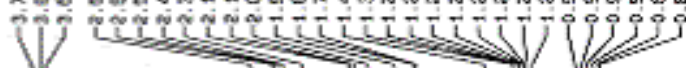

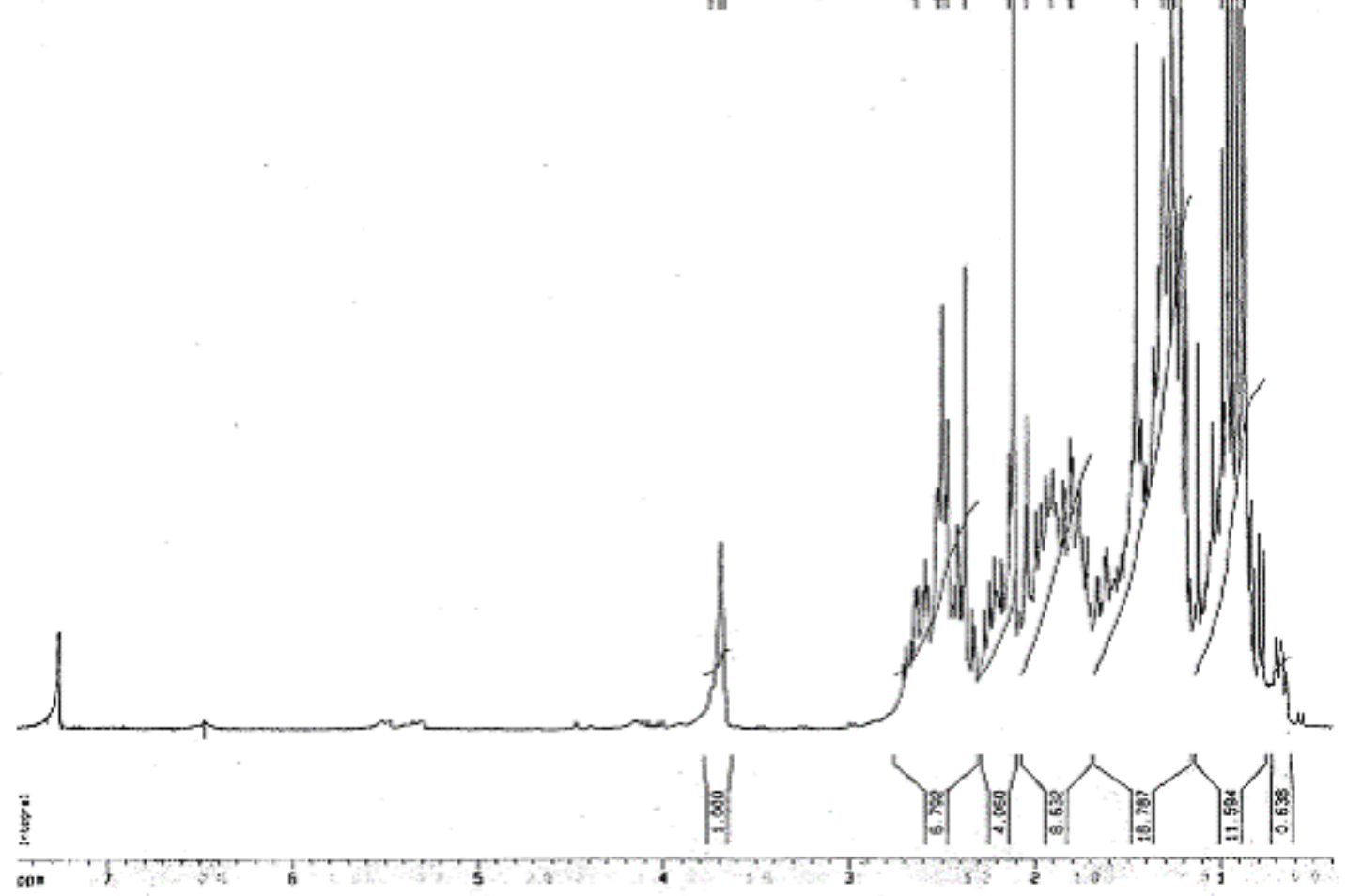




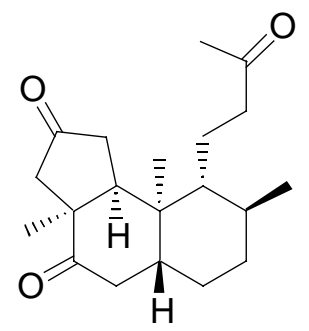

46

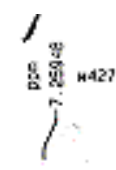

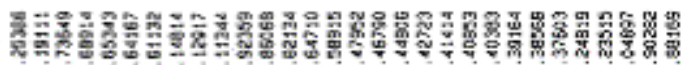

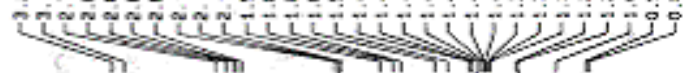

1
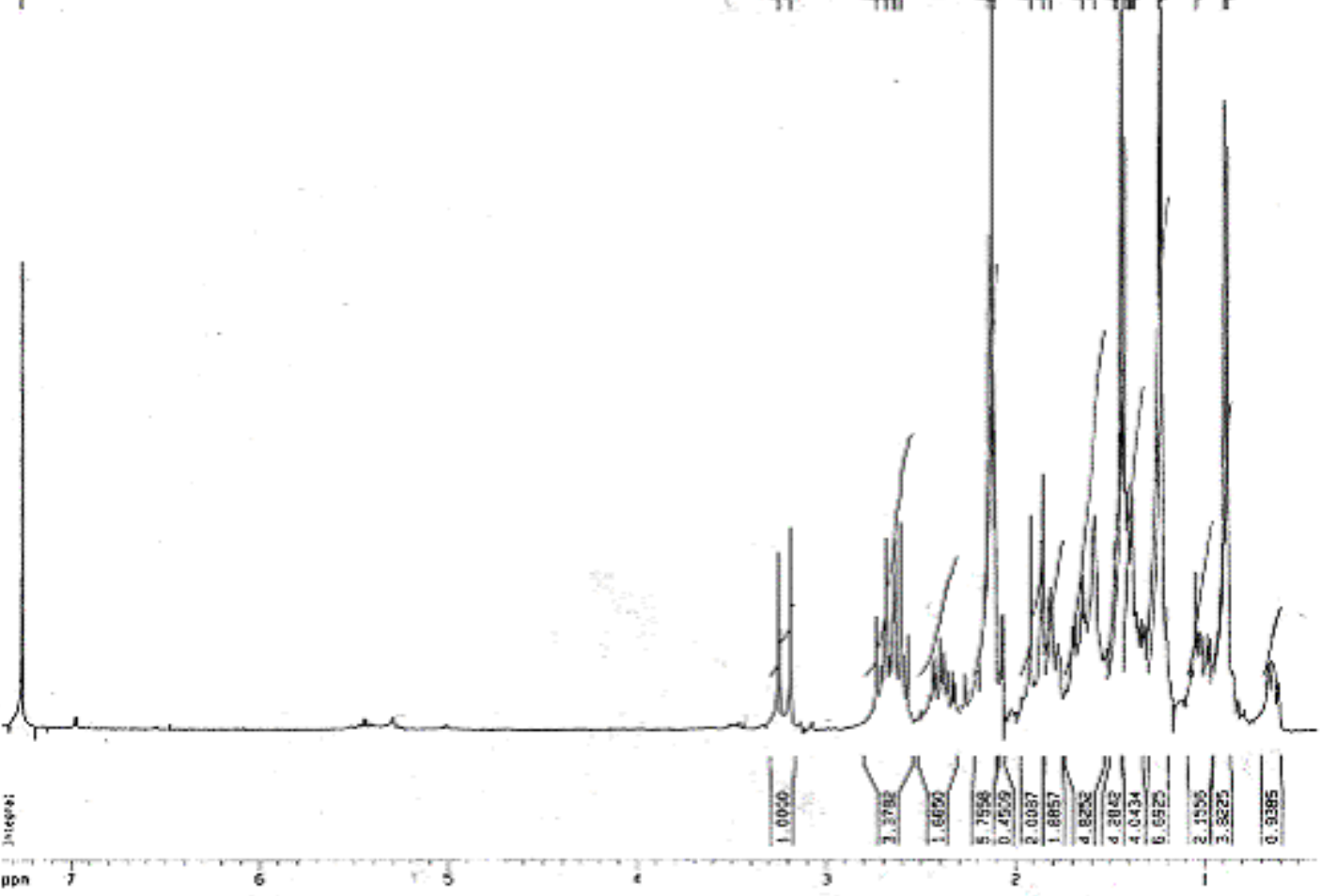


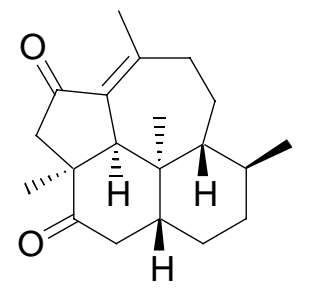

47

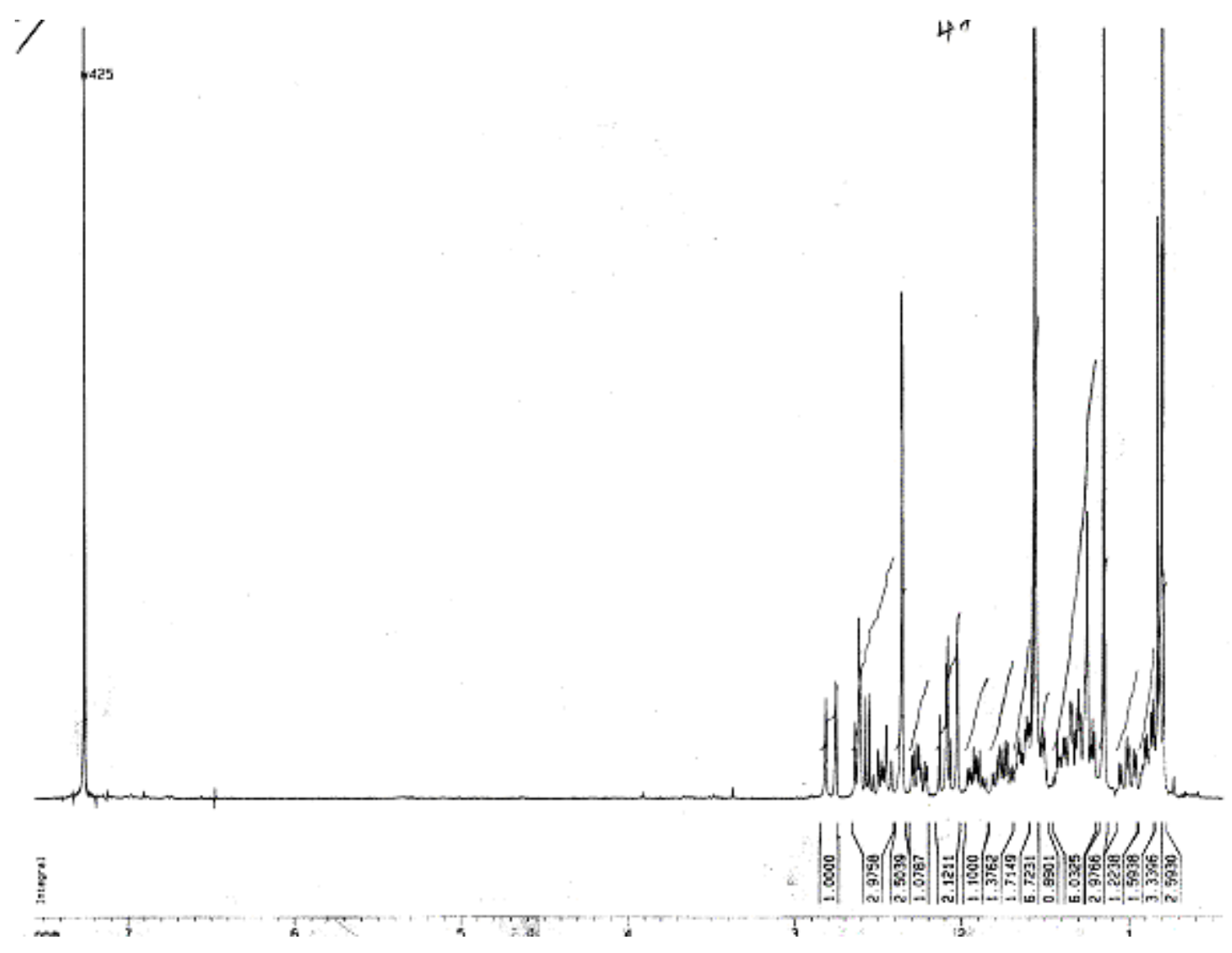




\section{Experimental details:}

\section{General:}

The reactions were performed under a nitrogen or argon atmosphere with flamedried glassware where needed. Solvents were distilled and dried according to standard procedures. NMR spectra were recorded on $300 \mathrm{MHz}$ spectrometer $\left({ }^{1} \mathrm{H}: 300 \mathrm{MHz}\right.$ and ${ }^{13} \mathrm{C}: 75 \mathrm{MHz}$ ) and are referenced with respect to the residual signal of the solvent. IR spectra were recorded on a FT IR spectrometer. Mass spectra were recorded on a HRMS spectrometer. Flash chromatography was performed on silica gel 230-400 mesh. TLC was carried out on Silica Gel $60 \mathrm{~F}_{254}(0.5 \mathrm{~mm}$ thickness $)$.

\section{Experimental Section}

Lactone 9: To a stirred solution of diisopropyl amine (19.9 ml, $142.1 \mathrm{mmol})$ in THF (200 ml) at $-78{ }^{\circ} \mathrm{C}$ was added $n$-BuLi $(94.7 \mathrm{ml}, 142.1 \mathrm{mmol}, 1.5 \mathrm{M}$ in hexane). The reaction mixture was warmed to $0{ }^{\circ} \mathrm{C}$ and stirred for $20 \mathrm{~min}$. The resulting solution was then cooled to $-78{ }^{\circ} \mathrm{C}$ and a solution of lactone 8 (12.5 g, 109.6 mmol) in THF (200 ml) was added via cannula. The reaction mixture was stirred for $1 \mathrm{~h}$ at $-78{ }^{\circ} \mathrm{C}$ and a solution of allyl bromide $(28.3 \mathrm{ml}, 327.9 \mathrm{mmol})$ in THF $(35 \mathrm{ml})$ was added. Stirred for $2 \mathrm{~h}$ at $-78{ }^{\circ} \mathrm{C}$ and warmed to $-50{ }^{\circ} \mathrm{C}$ and stirred for $4 \mathrm{~h}$ and finally the reaction was quenched by the addition of saturated $\mathrm{NH}_{4} \mathrm{Cl}$ solution $(60 \mathrm{ml})$, extracted with $\mathrm{Et}_{2} \mathrm{O}(3 \times 80 \mathrm{ml})$, dried and column chromatographed over silica gel using hexane:EtOAc to furnish lactone 9 (16.4 g, 97\%). IR $\left(\mathrm{CHCl}_{3}, \mathrm{v}, \mathrm{cm}^{-1}\right): 2930,1731$, 1641. ${ }^{1}$ HNMR $\left(300 \mathrm{MHz}, \mathrm{CDCl}_{3}\right): \delta 5.76(\mathrm{ddt}, \mathrm{J}=17,10,7 \mathrm{~Hz}, 1 \mathrm{H}), 5.11(\mathrm{~d}, \mathrm{~J}=17$ $\mathrm{Hz}, 1 \mathrm{H}), 5.09(\mathrm{~d}, \mathrm{~J}=10 \mathrm{~Hz}, 1 \mathrm{H}), 4.28(\mathrm{~m}, 2 \mathrm{H}), 2.70(\mathrm{~m}, 1 \mathrm{H}), 2.40(\mathrm{~m}, 1 \mathrm{H}), 2.23$ (dt, J 
$=8,4 \mathrm{~Hz}, 1 \mathrm{H}), 1.96-1.88(\mathrm{~m}, 2 \mathrm{H}), 1.57(\mathrm{~m}, 1 \mathrm{H}), 1.08(\mathrm{~d}, \mathrm{~J}=6.4 \mathrm{~Hz}, 3 \mathrm{H}) .{ }^{13} \mathbf{C N M R}$ (75 MHz, $\left.\mathrm{CDCl}_{3}\right): \delta 173.2,134.8,117.5,67.4,47.4,33.1,30.7,29.4,20.1$. HRMS $(\mathrm{m} / \mathrm{z})$ : calculated for $\mathrm{C}_{9} \mathrm{H}_{14} \mathrm{O}_{2}: 154.0994$ found: $154.0996 \pm 0.0005$.

Amide 10: To a stirred solution of $N, O$-dimethylhydroxylamine $(4.57 \mathrm{~g}, 46.9 \mathrm{mmol})$ in $\mathrm{CH}_{2} \mathrm{Cl}_{2}(235 \mathrm{ml})$ at $0{ }^{\circ} \mathrm{C}$ was added a solution of $\mathrm{Me}_{3} \mathrm{Al}(14 \mathrm{ml}, 27.8 \mathrm{mmol}, 2 \mathrm{M}$ in toluene) and stirred for 20 min warming to room temperature. The resulting solution was gain cooled to $0{ }^{\circ} \mathrm{C}$ and a solution of lactone 9 (3.61 g, $\left.23.44 \mathrm{mmol}\right)$ in $\mathrm{CH}_{2} \mathrm{Cl}_{2}$ (100 ml) was added and stirred at $\mathrm{rt}$ for $17 \mathrm{~h}$. The reaction was quenched by the addition of tartaric acid $(50 \mathrm{ml}, 1 \mathrm{M})$ and extracted with $\mathrm{CH}_{2} \mathrm{Cl}_{2}(3 \times 50 \mathrm{ml})$, dried and column chromatographed over silica gel using hexane:EtOAc furnished amide 10 (4.8 g, 95\%). IR $\left(\mathrm{CHCl}_{3}, v, \mathrm{~cm}^{-1}\right): 3417,2935,1644 .{ }^{1} \mathbf{H N M R}\left(300 \mathrm{MHz}, \mathrm{CDCl}_{3}\right): \delta 5.86-$ $5.60(\mathrm{~m}, 1 \mathrm{H}), 5.06(\mathrm{~d}, \mathrm{~J}=17 \mathrm{~Hz}, 1 \mathrm{H}), 4.98(\mathrm{~d}, \mathrm{~J}=10 \mathrm{~Hz}, 1 \mathrm{H}), 3.66(\mathrm{~m}, 2 \mathrm{H}), 3.67(\mathrm{~s}$, $3 \mathrm{H}), 3.18(\mathrm{~s}, 3 \mathrm{H}), 2.85-2.75(\mathrm{~m}, 1 \mathrm{H}), 2.48-2.37(\mathrm{~m}, 1 \mathrm{H}), 2.28-2.15(\mathrm{~m}, 1 \mathrm{H}), 2.05-1.41$ (m, 3H), $0.97(\mathrm{~d}, \mathrm{~J}=6.8 \mathrm{~Hz}, 3 \mathrm{H}) .{ }^{13} \mathbf{C N M R}\left(75 \mathrm{MHz}, \mathrm{CDCl}_{3}\right): \delta 176.4,136.2,116.3$, 61.4, 60.5, 45.9, 37.8, 32.2, 31.3, 16.5. HRMS (m/z): calculated for $\mathrm{C}_{11} \mathrm{H}_{21} \mathrm{NO}_{3}$ : 216.1600 found: $216.1605 \pm 0.0006$.

Chloroamide 11: To a stirred solution of amide 10 (4.8 g, $22.3 \mathrm{mmol})$ in THF (200 ml) at $0{ }^{\circ} \mathrm{C}$ was added $\mathrm{Ph}_{3} \mathrm{P}(8.1 \mathrm{~g}, 30.9 \mathrm{mmol})$ and $N$-chlorosuccinimide $(4.13 \mathrm{~g}, 30.9$ mmol) and the reaction mixture was stirred at room temperature for $17 \mathrm{~h}$. The reaction was diluted with $50 \mathrm{ml}$ of water and extracted with $\mathrm{Et}_{2} \mathrm{O}(3 \times 80 \mathrm{ml})$, dried and column chromatographed over silica gel using hexane:EtOAc provided chloroamide $11(4.8 \mathrm{~g}, 92 \%)$. IR $\left(\mathrm{CHCl}_{3}, \mathrm{v}, \mathrm{cm}^{-1}\right): 2965,1731,1660,1442 .{ }^{1} \mathrm{HNMR}$ (300 MHz, $\left.\mathrm{CDCl}_{3}\right): \delta 5.78-5.72(\mathrm{dd}, \mathrm{J}=17,10 \mathrm{~Hz}, 1 \mathrm{H}), 5.06(\mathrm{~d}, \mathrm{~J}=17 \mathrm{~Hz}, 1 \mathrm{H}), 4.98$ 
$(\mathrm{d}, \mathrm{J}=10 \mathrm{~Hz}, 1 \mathrm{H}), 3.67(\mathrm{~s}, 3 \mathrm{H}), 3.70-3.40(\mathrm{~m}, 2 \mathrm{H}), 3.18(\mathrm{~s}, 3 \mathrm{H}), 2.90-2.80(\mathrm{~m}, 1 \mathrm{H})$, 2.52-2.38 (m, 1H), 2.25-2.12 (m, 1H), 2.05-1.83 (m, 2H), 1.64-1.56 (m, 1H), $0.96(\mathrm{~d}$, $\mathrm{J}=6.5 \mathrm{~Hz}, 3 \mathrm{H}) .{ }^{13} \mathbf{C N M R}\left(75 \mathrm{MHz}, \mathrm{CDCl}_{3}\right): \delta 175.5,136.0,116.3,61.3,45.3,42.8$, 37.2, 33.1, 32.7, 15.8. HRMS (m/z): calculated for $\mathrm{C}_{11} \mathrm{H}_{20} \mathrm{NO}_{2} \mathrm{Cl}$ : 198.1494 found: $198.1490 \pm 0.0006$

Chloroaldehyde 12: To a stirred solution of chloroamide 11 (4.8 g, $20.6 \mathrm{mmol})$ in THF (200 ml) at $-78{ }^{\circ} \mathrm{C}$ were added DIBAL-H $(20.6 \mathrm{ml}, 30.9 \mathrm{mmol})$ and the reaction mixture was stirred for $2 \mathrm{~h}$ at $-78{ }^{\circ} \mathrm{C}$. The reaction was then quenched by the addition of a saturated solution of Rochelle salt $(100 \mathrm{ml})$ and stirred at $\mathrm{rt}$ for $1 \mathrm{~h}$, extracted with $\mathrm{Et}_{2} \mathrm{O}(3 \times 50 \mathrm{ml})$, dried and column chromatographed over silica gel using hexane:EtOAc afforded chloroaldehyde $12(3.4 \mathrm{~g}, 95 \%)$. IR $\left(\mathrm{CHCl}_{3}, \mathrm{v}, \mathrm{cm}^{-1}\right)$ : 2966, 1725, 1641, 1444. ${ }^{1}$ HNMR (300 MHz, $\left.\mathrm{CDCl}_{3}\right): \delta 9.67$ (d, J = 2 Hz, 1H), 5.80$5.69(\mathrm{dd}, \mathrm{J}=17 \mathrm{~Hz}, 10 \mathrm{~Hz}, 1 \mathrm{H}), 5.07(\mathrm{~d}, \mathrm{~J}=17 \mathrm{~Hz}, 1 \mathrm{H}), 5.05(\mathrm{~d}, \mathrm{~J}=10 \mathrm{~Hz}, 1 \mathrm{H})$, 3.69-3.45 (m, 2H), 2.52-2.14 (m, 3H), 2.52-2.14 (m, 3H), 1.95-1.54 (m, 3H), $0.96(\mathrm{~d}$, $\mathrm{J}=6.8 \mathrm{~Hz}, 3 \mathrm{H}) .{ }^{13} \mathbf{C N M R}\left(75 \mathrm{MHz}, \mathrm{CDCl}_{3}\right): \delta 203.9,135.5,116.8,55.5,42.7,36.6$, 29.6, 29.1, 15.6. HRMS (m/z): calculated for $\mathrm{C}_{9} \mathrm{H}_{15} \mathrm{OCl}\left(\mathrm{M}-\mathrm{CH}_{3}\right)^{+}: 159.0577$ found: $159.0571 \pm 0.0005$.

Dibromide 13: To a solution of $\mathrm{CBr}_{4}(27.3 \mathrm{~g}, 82.3 \mathrm{mmol})$ in $\mathrm{CH}_{2} \mathrm{Cl}_{2}(80 \mathrm{ml})$ at $0{ }^{\circ} \mathrm{C}$ was added $\mathrm{Ph}_{3} \mathrm{P}(43.2 \mathrm{~g}, 43.1 \mathrm{mmol})$ in $\mathrm{CH}_{2} \mathrm{Cl}_{2}(80 \mathrm{ml})$ via canula and stirred at $\mathrm{rt}$ for $10 \mathrm{~min}$. The reaction mixture was again cooled to $0{ }^{\circ} \mathrm{C}$ and to this was added chloroaldehyde $12(3.4 \mathrm{~g}, 19.5 \mathrm{mmol})$ in $\mathrm{CH}_{2} \mathrm{Cl}_{2}(80 \mathrm{ml})$ and stirred for further 20 min at $0{ }^{\circ} \mathrm{C}$. Water $(50 \mathrm{ml})$ was added to quench the reaction, extracted with $\mathrm{CH}_{2} \mathrm{Cl}_{2}$ ( $3 \times 80 \mathrm{ml}$ ), dried and column chromatographed over silica gel using hexane:EtOAc 
yielded the dibromide $\mathbf{1 3}(6.41 \mathrm{~g}, 100 \%)$. IR $\left(\mathrm{CHCl}_{3}, v, \mathrm{~cm}^{-1}\right): 2963,2358,1641$, 1444. ${ }^{1}$ HNMR (300 MHz, $\left.\mathrm{CDCl}_{3}\right): \delta 6.21(\mathrm{~d}, \mathrm{~J}=10 \mathrm{~Hz}, 1 \mathrm{H}), 5.80-5.60(\mathrm{dd}, \mathrm{J}=17$ $\mathrm{Hz}, 10 \mathrm{~Hz}, 1 \mathrm{H})$, 5.09-5.02 (m, 2H), 3.56-3.45 (m, 2H), 2.40-2.38 (m, 1H), 2.26-2.07 (m, 2H), 1.94-1.80 (m, 2H), 1.54-1.48 (m, 1H), 0.95 (d, J = 6.8 Hz, 3H). ${ }^{13}$ CNMR (75 MHz, $\left.\mathrm{CDCl}_{3}\right): \delta 140.6,135.3,116.9,89.4,48.4,43.1,36.2,35.2,33.4,16.6$. HRMS (m/z): calculated for $\mathrm{C}_{10} \mathrm{H}_{15} \mathrm{Br}_{2} \mathrm{Cl}$ : 286.8838 found: $286.8845 \pm 0.0008$.

Chloroester 14: To a stirred solution of dibromide $(6.41 \mathrm{~g}, 19.5 \mathrm{mmol})$ in THF (150 ml) at $-78{ }^{\circ} \mathrm{C}$ was added $n$-BuLi $(30.7 \mathrm{ml}, 41.7 \mathrm{mmol}, 1.35 \mathrm{M}$ in hexane) and stirred for $20 \mathrm{~min}$ at this temperature. To this was added a solution of methyl chloroformate (3.07 ml, $39.7 \mathrm{mmol})$ in THF $(20 \mathrm{ml})$ via canula and stirred for $2 \mathrm{~h}$ warming to rt. The reaction was quenched by the addition of saturated $\mathrm{NH}_{4} \mathrm{Cl}$ solution $(30 \mathrm{ml})$ and extracted with $\mathrm{Et}_{2} \mathrm{O}$, dried and column chromatographed over silica gel using hexane:EtOAc afforded the chloroester $14(4.3 \mathrm{~g}, 95 \%)$. IR $\left(\mathrm{CHCl}_{3}, \mathrm{v}, \mathrm{cm}^{-1}\right): 2962$, 2232, 1715, 1434, 1255. ${ }^{1} \mathbf{H N M R}\left(300 \mathrm{MHz}, \mathrm{CDCl}_{3}\right): \delta 5.83(\mathrm{dd}, \mathrm{J}=17,10 \mathrm{~Hz}, 1 \mathrm{H})$, $5.16(\mathrm{~d}, \mathrm{~J}=17 \mathrm{~Hz}, 1 \mathrm{H}), 5.10(\mathrm{~d}, \mathrm{~J}=10 \mathrm{~Hz}, 1 \mathrm{H}), 3.76(\mathrm{~s}, 3 \mathrm{H}), 3.75-3.60(\mathrm{~m}, 1 \mathrm{H})$, 3.58-3.48 (m, 1H), 2.63-2.52 (m, 1H), 2.38-2.24 (m, 2H), 2.07-1.92 (m, 2H), 1.70$1.61(\mathrm{~m}, 1 \mathrm{H}), 1.04(\mathrm{~d}, \mathrm{~J}=6.8 \mathrm{~Hz}, 3 \mathrm{H}) .{ }^{13} \mathbf{C N M R}\left(75 \mathrm{MHz}, \mathrm{CDCl}_{3}\right): \delta 153.8,134.7$, 117.4, 89.8, 75.3, 52.5, 42.8, 37.7, 35.5, 35.0, 32.7, 17.2. HRMS (m/z): calculated for $\mathrm{C}_{12} \mathrm{H}_{17} \mathrm{O}_{2} \mathrm{Cl}: 213.0682$ found: $213.0678 \pm 0.0006$.

Alkene ester 15: To a stirred solution of copper(I)iodide (10.9 g, $57.3 \mathrm{mmol})$ in THF (195 ml) at $0{ }^{\circ} \mathrm{C}$ was added $\mathrm{MeLi}\left(71.7 \mathrm{ml}, 114.7 \mathrm{mmol}, 1.6 \mathrm{M}^{\text {in }} \mathrm{Et}_{2} \mathrm{O}\right)$ and stirred for 15 min at $0{ }^{\circ} \mathrm{C}$. The resulting solution was cooled to $-50{ }^{\circ} \mathrm{C}$ and a solution of chloroester 14 (4.38 g, $19.1 \mathrm{mmol})$ in THF (190 ml) was added via canula and stirred 
for $2 \mathrm{~h}$ at that temperature. The reaction mixture was then quenched by the addition of glacial acetic acid $(6.4 \mathrm{ml})$ warmed to $-45^{\circ} \mathrm{C}$, and a solution of saturated $\mathrm{NH}_{4} \mathrm{Cl}(20$ ml) was added. Extracted with $\mathrm{Et}_{2} \mathrm{O}(3 \times 20 \mathrm{ml})$, dried and column chromatographed over silica gel using hexane: EtOAc furnished the alkene ester 15 (4.62 g, 98\%). IR $\left(\mathrm{CHCl}_{3}, v, \mathrm{~cm}^{-1}\right): 2974,1715,1642,1434 .{ }^{1} \mathrm{HNMR}\left(300 \mathrm{MHz}, \mathrm{CDCl}_{3}\right): \delta 5.77-5.75$ (m, 1H), 5.70-5.50 (m, 1H), $4.97(\mathrm{~d}, \mathrm{~J}=17 \mathrm{~Hz}, 1 \mathrm{H}), 4.93(\mathrm{~d}, \mathrm{~J}=10 \mathrm{~Hz}, 1 \mathrm{H}), 3.80$ (td, $\mathrm{J}=10,4 \mathrm{~Hz}, 1 \mathrm{H}), 3.70-3.47(\mathrm{~m}, 2 \mathrm{H}), 3.66(\mathrm{~s}, 3 \mathrm{H}), 2.55-2.40(\mathrm{~m}, 1 \mathrm{H}), 2.15-1.90(\mathrm{~m}$, 1H), 1.84-1.65 (m, 7H), 1.55-1.45 (m, 1H), 1.00 (d, J = 6.5 Hz, 3H). ${ }^{13}$ CNMR (75 $\left.\mathrm{MHz}, \mathrm{CDCl}_{3}\right): \delta 166.6,161.0,136.5,119.1,115.4,50.6,44.7,43.0,37.2,35.0,32.2$, 19.5, 16.4. HRMS (m/z): calculated for $\mathrm{C}_{13} \mathrm{H}_{21} \mathrm{O}_{2} \mathrm{Cl}: 244.1230$ found: $244.1223 \pm$ 0.0007 .

Allyl alcohol 16: To a stirred solution of alkene ester 15 (4.6 g, $18.7 \mathrm{mmol})$ in THF $(200 \mathrm{ml})$ at $0{ }^{\circ} \mathrm{C}$ was added $\mathrm{LiAlH}_{4}(0.77 \mathrm{~g}, 20.6 \mathrm{mmol})$ and the reaction mixture was stirred for $3 \mathrm{~h}$ warming to rt. The reaction was quenched by the addition of saturated solution of Rochelle salt $(80 \mathrm{ml})$ and extracted with $\mathrm{Et}_{2} \mathrm{O}(3 \times 20 \mathrm{ml})$, dried and column chromatographed over silica gel using hexane: EtOAc furnished the allyl alcohol 16 (3.85 g, 95\%). IR $\left(\mathrm{CHCl}_{3}, \mathrm{v}, \mathrm{cm}^{-1}\right): 3346,2968,1639,1447 .{ }^{1} \mathbf{H N M R}(300$ $\left.\mathrm{MHz}, \mathrm{CDCl}_{3}\right): \delta 5.68-5.56(\mathrm{~m}, 2 \mathrm{H}), 4.99(\mathrm{~d}, \mathrm{~J}=17 \mathrm{~Hz}, 1 \mathrm{H}), 4.93(\mathrm{~d}, \mathrm{~J}=10 \mathrm{~Hz}, 1 \mathrm{H})$, $4.11(\mathrm{dd}, \mathrm{J}=12.2,7.5 \mathrm{~Hz}, 1 \mathrm{H}), 4.02(\mathrm{dd}, \mathrm{J}=12.2,7.5 \mathrm{~Hz}, 1 \mathrm{H}), 3.62(\mathrm{dd}, \mathrm{J}=10.8,7.1$ $\mathrm{Hz}, 1 \mathrm{H}), 3.50(\mathrm{dd}, \mathrm{J}=10.8,7.1 \mathrm{~Hz}, 1 \mathrm{H}), 2.33-2.28(\mathrm{~m}, 1 \mathrm{H}), 2.18(\mathrm{td}, \mathrm{J}=10,4 \mathrm{~Hz}$, 1H), 2.04-2.00 (m, 1H), 1.80-1.53 (m, 1H), $1.63(\mathrm{~s}, 3 \mathrm{H}), 1.38-1.25(\mathrm{~m}, 2 \mathrm{H}), 0.98(\mathrm{~d}, \mathrm{~J}$ $=6.5 \mathrm{~Hz}, 3 \mathrm{H}) .{ }^{13} \mathbf{C N M R}\left(75 \mathrm{MHz}, \mathrm{CDCl}_{3}\right): \delta 137.2,127.9,115.3,58.1,46.2,43.1$, 
37.2, 34.3, 31.9, 18.5, 16.5. HRMS (m/z): calculated for $\mathrm{C}_{12} \mathrm{H}_{21} \mathrm{OCl}\left(\mathrm{M}-\mathrm{OCH}_{3}\right)$ : 185.1097 found: $185.1103 \pm 0.0005$.

Chloroalcohol 17: To a stirred solution of allyl acohol 16 (3.09 g, $14.2 \mathrm{mmol})$ in $\mathrm{CH}_{2} \mathrm{Cl}_{2}(140 \mathrm{ml})$ at $0{ }^{\circ} \mathrm{C}$ was added imidazole $(2.42 \mathrm{~g}, 35.6 \mathrm{mmol})$ and tertbutyldimethylsilane (2.36 g, $15.6 \mathrm{mmol})$. The reaction mixture was stirred for $2 \mathrm{~h}$ at rt, water $(50 \mathrm{ml})$ was added to quench the reaction, extracted with $\mathrm{CH}_{2} \mathrm{Cl}_{2}(3 \times 15$ $\mathrm{ml}$ ), dried and column chromatographed over silica gel using hexane:EtOAc afforded the TBDMS ether 16a (4.05 g, 85\%). ${ }^{1}$ HNMR (300 MHz, $\left.\mathrm{CDCl}_{3}\right): \delta 5.63$ (dd, J = 17, $10 \mathrm{~Hz}, 1 \mathrm{H}), 5.42(\mathrm{td}, \mathrm{J}=6.5,1 \mathrm{~Hz}, 1 \mathrm{H}), 4.96(\mathrm{~d}, \mathrm{~J}=17 \mathrm{~Hz}, 1 \mathrm{H}), 4.92(\mathrm{~d}, \mathrm{~J}=10 \mathrm{~Hz}$, 1H), $4.12(\mathrm{~d}, \mathrm{~J}=6.5 \mathrm{~Hz}, 2 \mathrm{H}), 3.62(\mathrm{~d}, \mathrm{~J}=10.8,7.7 \mathrm{~Hz}, 1 \mathrm{H}), 3.50(\mathrm{dd}, \mathrm{J}=10.8,7.7$ $\mathrm{Hz}, 1 \mathrm{H}), 2.38-2.25(\mathrm{~m}, 1 \mathrm{H}), 2.18(\mathrm{td}, \mathrm{J}=10,4 \mathrm{~Hz}, 1 \mathrm{H}), 2.04-1.70(\mathrm{~m}, 2 \mathrm{H}), 1.63$ (s, $3 \mathrm{H}), 1.40-1.25(\mathrm{~m}, 2 \mathrm{H}), 0.99(\mathrm{~d}, \mathrm{~J}=6.5 \mathrm{~Hz}, 3 \mathrm{H})$.

To a stirred solution of TBDMS ether 16a $(3.54 \mathrm{~g}, 10.6 \mathrm{mmol})$ in $\operatorname{THF}(53 \mathrm{ml})$ at $0{ }^{\circ} \mathrm{C}$ was added 9-BBN (3.89 g, $15.9 \mathrm{mmol})$ and the reaction mixture was stirred overnight at this temperature. To this was added a freshly prepared solution of $3 \mathrm{M} \mathrm{NaOH}$ solution (57 ml) followed by $\mathrm{H}_{2} \mathrm{O}_{2}$ solution $(30 \%, 110 \mathrm{ml}$ ) and the reaction mixture was stirred for $2 \mathrm{~h}$ at $\mathrm{rt}$. The reaction was quenched by the addition of saturated $\mathrm{NH}_{4} \mathrm{Cl}$ solution, adjusted the $\mathrm{pH}$ to 7 , extracted with $\mathrm{Et}_{2} \mathrm{O}(3 \times 10 \mathrm{ml})$, dried and column chromatographed over silca ge 1 using hexane:EtOAc furnished the chloroalcohol 17 (3.51 g, 94\%). IR $\left(\mathrm{CHCl}_{3}, \mathrm{v}, \mathrm{cm}^{-1}\right)$ : 3362, 2929, 1661, 1471, 1382, 1255. ${ }^{1} \mathrm{HNMR}\left(300 \mathrm{MHz}, \mathrm{CDCl}_{3}\right): \delta 5.48(\mathrm{dt}, \mathrm{J}=6.5 \mathrm{~Hz}, 1 \mathrm{H}), 4.13(\mathrm{dd}, \mathrm{J}=6.5,1$ $\mathrm{Hz}, 2 \mathrm{H}), 3.65-3.44(\mathrm{~m}, 4 \mathrm{H}), 2.10(\mathrm{td}, \mathrm{J}=10,3.5 \mathrm{~Hz}, 1 \mathrm{H}), 1.93-1.65(\mathrm{~m}, 8 \mathrm{H}), 1.58(\mathrm{~s}$, $3 \mathrm{H}), 0.95(\mathrm{~d}, \mathrm{~J}=6.5 \mathrm{~Hz}, 3 \mathrm{H}), 0.06(\mathrm{~s}, 6 \mathrm{H}) .{ }^{13} \mathbf{C N M R}\left(75 \mathrm{MHz}, \mathrm{CDCl}_{3}\right): \delta 138.0$, 
128.6, 63.1, 59.3, 45.9, 43.3, 37.5, 32.3, 30.7, 26.0, 18.3, 16.8, -5.1. HRMS (m/z): calculated for $\mathrm{C}_{18} \mathrm{H}_{37} \mathrm{O}_{2} \mathrm{ClSi}$ : $\left(\mathrm{M}_{-} \mathrm{C}_{4} \mathrm{H}_{9}\right)^{+}: 291.1547$ found: $291.1543 \pm 0.0008$.

Nitrile 18: To a stirred solution of chloroalcohol 17 (3.51 g, $10.0 \mathrm{mmol})$ in $\mathrm{CH}_{2} \mathrm{Cl}_{2}$ $(100 \mathrm{ml})$ at $0{ }^{\circ} \mathrm{C}$ was added $\operatorname{DMAP}(0.367 \mathrm{~g}, 3 \mathrm{mmol})$ and $\mathrm{Et}_{3} \mathrm{~N}(4.18 \mathrm{ml}, 30.0 \mathrm{mmol})$ followed by tert-butyldiphenylsilane $(2.86 \mathrm{~g}, 11.0 \mathrm{mmol})$. The reaction mixture was stirred at $\mathrm{rt}$ for $2 \mathrm{~h}$, water $(10 \mathrm{ml})$ was added to quench the reaction, extracted with $\mathrm{CH}_{2} \mathrm{Cl}_{2}$ (3 x15 ml), dried and column chromatographed over silica gel using hexae:EtOAc furnished the chloride 17a $(5.87 \mathrm{~g}, 100 \%)$. ${ }^{1}$ HNMR $(300 \mathrm{MHz}$, $\left.\mathrm{CDCl}_{3}\right): \delta 7.70-7.36(\mathrm{~m}, 10 \mathrm{H}), 5.47(\mathrm{dt}, \mathrm{J}=6.3,1.2 \mathrm{~Hz}, 1 \mathrm{H}), 4.20-4.10(\mathrm{~m}, 2 \mathrm{H}), 3.69-$ $3.46(\mathrm{~m}, 4 \mathrm{H}), 2.12-1.70(\mathrm{~m}, 9 \mathrm{H}), 1.58(\mathrm{~s}, 3 \mathrm{H}), 1.07$ (s, 9H), $0.95(\mathrm{~d}, \mathrm{~J}=6.5 \mathrm{~Hz}, 3 \mathrm{H})$, $0.92(\mathrm{~s}, 9 \mathrm{H}), 0.09(\mathrm{~s}, 6 \mathrm{H})$.

To a stirred solution of chloride $17 \mathbf{a}(5.87 \mathrm{~g}, 10.0 \mathrm{mmol})$ in $\mathrm{CH}_{3} \mathrm{CN}(200 \mathrm{ml})$ was added $\mathrm{KCN}(1.30 \mathrm{~g}, 20 \mathrm{mmol})$ and 18-crown-6 ether $(5.29 \mathrm{~g}, 20 \mathrm{mmol})$. The reaction mixture was stirred overnight, solvent was evaporated off and the residue was column chromatographed over silca gel using hexane:EtOAc afforded the nitrile $\mathbf{1 8}$ (5.66 g, 98\%). IR $\left(\mathrm{CHCl}_{3}, v, \mathrm{~cm}^{-1}\right): 2920,2246,1958,1888,1822,1660,1589 .{ }^{1} \mathbf{H N M R}(300$ $\left.\mathrm{MHz}, \mathrm{CDCl}_{3}\right): \delta 7.70-7.30(\mathrm{~m}, 10 \mathrm{H}), 5.47(\mathrm{td}, \mathrm{J}=6.4 \mathrm{~Hz}, 1 \mathrm{H}), 4.05-3.88(\mathrm{~m}, 2 \mathrm{H})$, 3.70-3.60 (m, 2H), 2.42-2.00 (m, 3H), 1.90-1.70 (m, 7H), $1.56(\mathrm{~s}, 3 \mathrm{H}), 1.05(\mathrm{~s}, 9 \mathrm{H})$, $0.95(\mathrm{~d}, \mathrm{~J}=6.5 \mathrm{~Hz}, 3 \mathrm{H}), 0.92(\mathrm{~s}, 9 \mathrm{H}), 0.09(\mathrm{~s}, 6 \mathrm{H}) .{ }^{13} \mathbf{C N M R}\left(75 \mathrm{MHz}, \mathrm{CDCl}_{3}\right): \delta$ $137.7,135.6,134.0,129.7,129.1,127.7,119.8,63.9,59.3,45.7,34.1,30.8,30.5$, 27.0, 26.2, 19.3, 18.4, 16.8, 14.9, -5.0. HRMS (m/z): calculated for $\mathrm{C}_{35} \mathrm{H}_{55} \mathrm{NO}_{2} \mathrm{Si}_{2}$ $\left(\mathrm{M}-\mathrm{C}_{4} \mathrm{H}_{9}\right)^{+}: 520.3067$ found: $520.3062 \pm 0.0016$. 
Aldehyde 19: To a stirred solution of nitrile 18 (5.66 g, $9.8 \mathrm{mmol})$ in toluene (190 $\mathrm{ml})$ at $-78{ }^{\circ} \mathrm{C}$ was added DIBAL-H $(9.8 \mathrm{ml}, 14.7 \mathrm{mmol}, 1.5 \mathrm{M}$ in toluene $)$ and stirred for $1 \mathrm{~h}$ at $-78{ }^{\circ} \mathrm{C}$ and quenched by the addition of saturated Rochelle salt $(50 \mathrm{ml})$. Extracted with $\mathrm{Et}_{2} \mathrm{O}(3 \times 25 \mathrm{ml})$, dried and column chromatographed over silica gel using hexane: EtOAc furnished the aldehyde $19(5.37 \mathrm{~g}, 94 \%)$. IR $\left(\mathrm{CHCl}_{3}, v, \mathrm{~cm}^{-1}\right)$ : 3049, 2930, 2711, 1728, 1472. ${ }^{1} \mathbf{H N M R}\left(300 \mathrm{MHz}, \mathrm{CDCl}_{3}\right): \delta 9.72(\mathrm{t}, \mathrm{J}=2 \mathrm{~Hz}, 1 \mathrm{H})$, 7.70-7.30 (m, 10H), $5.44(\mathrm{td}, \mathrm{J}=6.3,1.3 \mathrm{~Hz}, 1 \mathrm{H}), 4.25-4.15(\mathrm{~m}, 2 \mathrm{H}), 3.70-3.50(\mathrm{~m}$, $2 \mathrm{H}), 2.50-2.30(\mathrm{~m}, 2 \mathrm{H}), 2.05-1.95(\mathrm{~m}, 1 \mathrm{H}), 1.83-0.76(\mathrm{~m}, 21 \mathrm{H}), 1.55(\mathrm{~s}, 3 \mathrm{H}), 1.05(\mathrm{~s}$, 9H), 0.09 (s, 6H). ${ }^{13}$ CNMR (75 MHz, $\mathrm{CDCl}_{3}$ ): $\delta$ 202.0, 137.8, 135.6, 134.0, 129.5, $128.8,127.6,64.0,59.5,46.0,41.6,34.5,30.8,27.0,26.1,19.2,18.4,17.2,-5.0$. HRMS (m/z): calculated for $\mathrm{C}_{35} \mathrm{H}_{56} \mathrm{O}_{3} \mathrm{Si}_{2}\left(\mathrm{M}-\mathrm{C}_{4} \mathrm{H}_{9}\right)^{+}: 523.3064$ found: $523.3057 \pm$ 0.0016 .

Diene 20: To a stirred solution of methyltriphenylphosphonium iodide (7.48 g, 18.5 mmol) in THF $(180 \mathrm{ml})$ at $0{ }^{\circ} \mathrm{C}$ was added $n$-BuLi $(13.6 \mathrm{ml}, 18.5 \mathrm{mmol}, 1.36 \mathrm{M}$ in hexane) and stirred for $30 \mathrm{~min}$ at rt. To this was added a solution of aldehyde 19 (5.37 $\mathrm{g}, 9.2 \mathrm{mmol})$ in THF $(90 \mathrm{ml})$ via canula and stirred at $\mathrm{rt}$ for $12 \mathrm{~h}$. The reaction was quenched by the addition of saturated $\mathrm{NH}_{4} \mathrm{Cl}$ solution ( $10 \mathrm{ml}$ ), extracted with $\mathrm{Et}_{2} \mathrm{O}$ (3 x $20 \mathrm{ml}$ ), dried and column chromatographed over silica gel using hexane:EtOAc provided the diene $20(4.83 \mathrm{~g}, 90 \%)$. IR $\left(\mathrm{CHCl}_{3}, v, \mathrm{~cm}^{-1}\right)$ : 3051, 2929, 1641, 1589. ${ }^{1}$ HNMR $\left(300 \mathrm{MHz}, \mathrm{CDCl}_{3}\right): \delta 7.70-7.30(\mathrm{~m}, 10 \mathrm{H}), 5.80-5.60(\mathrm{~m}, 1 \mathrm{H}), 5.40(\mathrm{td}, \mathrm{J}=6$, $1.3 \mathrm{~Hz}, 1 \mathrm{H}), 4.96(\mathrm{~d}, \mathrm{~J}=17 \mathrm{~Hz}, 1 \mathrm{H}), 4.86(\mathrm{~d}, \mathrm{~J}=10 \mathrm{~Hz}, 1 \mathrm{H}), 4.12(\mathrm{~d}, \mathrm{~J}=6 \mathrm{~Hz}, 2 \mathrm{H})$, $3.60(\mathrm{t}, \mathrm{J}=4.3 \mathrm{~Hz}, 2 \mathrm{H}), 2.12-1.80(\mathrm{~m}, 3 \mathrm{H}), 1.70-1.10(\mathrm{~m}, 5 \mathrm{H}), 1.51(\mathrm{~s}, 3 \mathrm{H}), 1.05(\mathrm{~s}$, 9H), 0.97-0.80 (m, 12H), 0.09 (s, 6H). ${ }^{13}$ CNMR (75 MHz, $\left.\mathrm{CDCl}_{3}\right): \delta$ 139.2, 138.1, 
135.6, 134.1, 133.7, 129.6, 128.7, 127.6, 114.3, 64.1, 59.8, 46.4, 34.5, 34.1, 31.6, 26.9, 26.1, 19.3, 18.5, 17.3, -5.0. HRMS (m/z): calculated for $\mathrm{C}_{35} \mathrm{H}_{56} \mathrm{O}_{2} \mathrm{Si}_{2}(\mathrm{M}-$ $\left.\mathrm{C}_{4} \mathrm{H}_{9}\right)^{+}: 521.3271$ found: $521.3256 \pm 0.0016$.

Bromide 7: To a stirred solution of diene 20 (7.66 g, $13.2 \mathrm{mmol})$ in ethanol $(140 \mathrm{ml})$ at $\mathrm{rt}$ was added PPTS $(0.997 \mathrm{~g}, 3.9 \mathrm{mmol})$ and stirred for $20 \mathrm{~h}$. The reaction was quenched by the addition of saturated $\mathrm{NaHCO}_{3}$ solution $(20 \mathrm{ml})$ and extracted with $\mathrm{Et}_{2} \mathrm{O}(3 \times 50 \mathrm{ml}$ ), dried and column chromatographed over silica gel using hexane:EtOAc furnished the allyl alcohol 20a $(5.80 \mathrm{~g}, 94 \%)$. IR $\left(\mathrm{CHCl}_{3}, v, \mathrm{~cm}^{-1}\right)$ : 3353, 2934, 1654, 1638, 1565. ${ }^{1}$ HNMR (300 MHz, $\left.\mathrm{CDCl}_{3}\right): \delta$ 7.70-7.30 (m, 10H), 5.85-5.70 (m, 1H), $5.50(\mathrm{td}, \mathrm{J}=7,1.2 \mathrm{~Hz}, 1 \mathrm{H}), 4.98(\mathrm{~d}, \mathrm{~J}=17 \mathrm{~Hz}, 1 \mathrm{H}), 4.92(\mathrm{~d}, \mathrm{~J}=$ $10 \mathrm{~Hz}, 1 \mathrm{H}), 4.06(\mathrm{~d}, \mathrm{~J}=6 \mathrm{~Hz}, 2 \mathrm{H}), 3.70-3.50(\mathrm{~m}, 2 \mathrm{H}), 2.12-1.80(\mathrm{~m}, 3 \mathrm{H}), 1.80-1.10$ (m, 7H), 1.55 (s, 3H), 1.05 (s, 9H), $0.91(\mathrm{~d}, \mathrm{~J}=6.6 \mathrm{~Hz}, 3 \mathrm{H}) .{ }^{13} \mathrm{CNMR}(75 \mathrm{MHz}$, $\left.\mathrm{CDCl}_{3}\right): \delta 140.6,139.0,135.5,129.5,127.6,127.3,114.4,63.9,58.8,45.9,34.2,34.0$, 31.3, 30.9, 26.9, 25.9, 19.2, 18.6, 17.1, 14.1. HRMS (m/z): calculated for $\mathrm{C}_{30} \mathrm{H}_{44} \mathrm{O}_{2} \mathrm{Si}$ (M - $\left.\mathrm{C}_{4} \mathrm{H}_{9}\right)+: 407.2406$ found: $407.2411 \pm 0.0012$.

To a stirred solution of allyl alcohol 20a $(2.67 \mathrm{~g}, 5.7 \mathrm{mmol})$ in THF $(57 \mathrm{ml})$ at -45 ${ }^{\circ} \mathrm{C}$ was added methanesulfonyl chloride $(0.58 \mathrm{ml}, 7.4 \mathrm{mmol})$ and $\mathrm{Et}_{3} \mathrm{~N}(0.78 \mathrm{ml}, 17.2$ mmol) and stirred for $45 \mathrm{~min}$ at this temperature. The reaction was warmed to $0{ }^{\circ} \mathrm{C}$ and a solution of $\operatorname{LiBr}(2 \mathrm{~g}, 23 \mathrm{mmol})$ in THF $(20 \mathrm{ml})$ was added via canula and further stirred for $1 \mathrm{~h}$ at $0{ }^{\circ} \mathrm{C}$. The reaction was quenched by the addition of water $(10$ $\mathrm{ml})$, extracted with hexane $(3 \times 15 \mathrm{ml})$, organic phase was washed with saturated $\mathrm{NaHCO}_{3}(10 \mathrm{ml})$, brine $(10 \mathrm{ml})$, dried and concentrated. The crude bromide 7 (3.0 g, 99\%) thus obtained was used for the next step. 
Iodoester 6: To a stirred solution of dimethylmalonate $(5.90 \mathrm{ml}, 51 \mathrm{mmol})$ in THF (120 $\mathrm{ml})$ at $0{ }^{\circ} \mathrm{C}$ was added $\mathrm{NaH}(1.22 \mathrm{~g}, 51 \mathrm{mmol})$ and stirred for $10 \mathrm{~min}$ at $\mathrm{rt}$. To this was added a solution of iodobromide $21^{11}(4.47 \mathrm{~g}, 17 \mathrm{mmol})$ in THF (30 ml) via canula and stirred at $\mathrm{rt}$ for $17 \mathrm{~h}$. The reaction was quenched by saturated $\mathrm{NH}_{4} \mathrm{Cl}$ and extracted with $\mathrm{Et}_{2} \mathrm{O}$ :hexane (1:1) (3 x $\left.50 \mathrm{ml}\right)$, dried and column chromatographed over silica gel using hexane:EtOAc afforded the iodoester $6(4.0 \mathrm{~g}, 77 \%)$. IR $\left(\mathrm{CHCl}_{3}, \mathrm{v}, \mathrm{cm}^{-1}\right): 2953,1733$, 1436. ${ }^{1}$ HNMR (300 MHz, $\left.\mathrm{CDCl}_{3}\right): \delta 6.04(\mathrm{~s}, 1 \mathrm{H}), 3.73(\mathrm{~s}, 6 \mathrm{H}), 3.63(\mathrm{t}, \mathrm{J}=7.9 \mathrm{~Hz}, 1 \mathrm{H})$, $2.80(\mathrm{~d}, \mathrm{~J}=7.9 \mathrm{~Hz}, 2 \mathrm{H}), 1.88(\mathrm{~s}, 3 \mathrm{H}) .{ }^{13} \mathbf{C N M R}\left(75 \mathrm{MHz}, \mathrm{CDCl}_{3}\right): \delta 169.0,143.2,77.6$, 52.6, 49.4, 37.4, 23.4. HRMS (m/z): calculated for $\mathrm{C}_{9} \mathrm{H}_{13} \mathrm{IO}_{4}\left(\mathrm{M}-\mathrm{OCH}_{3}\right)^{+}: 280.9675$ found: $280.9689 \pm 0.0008$. 


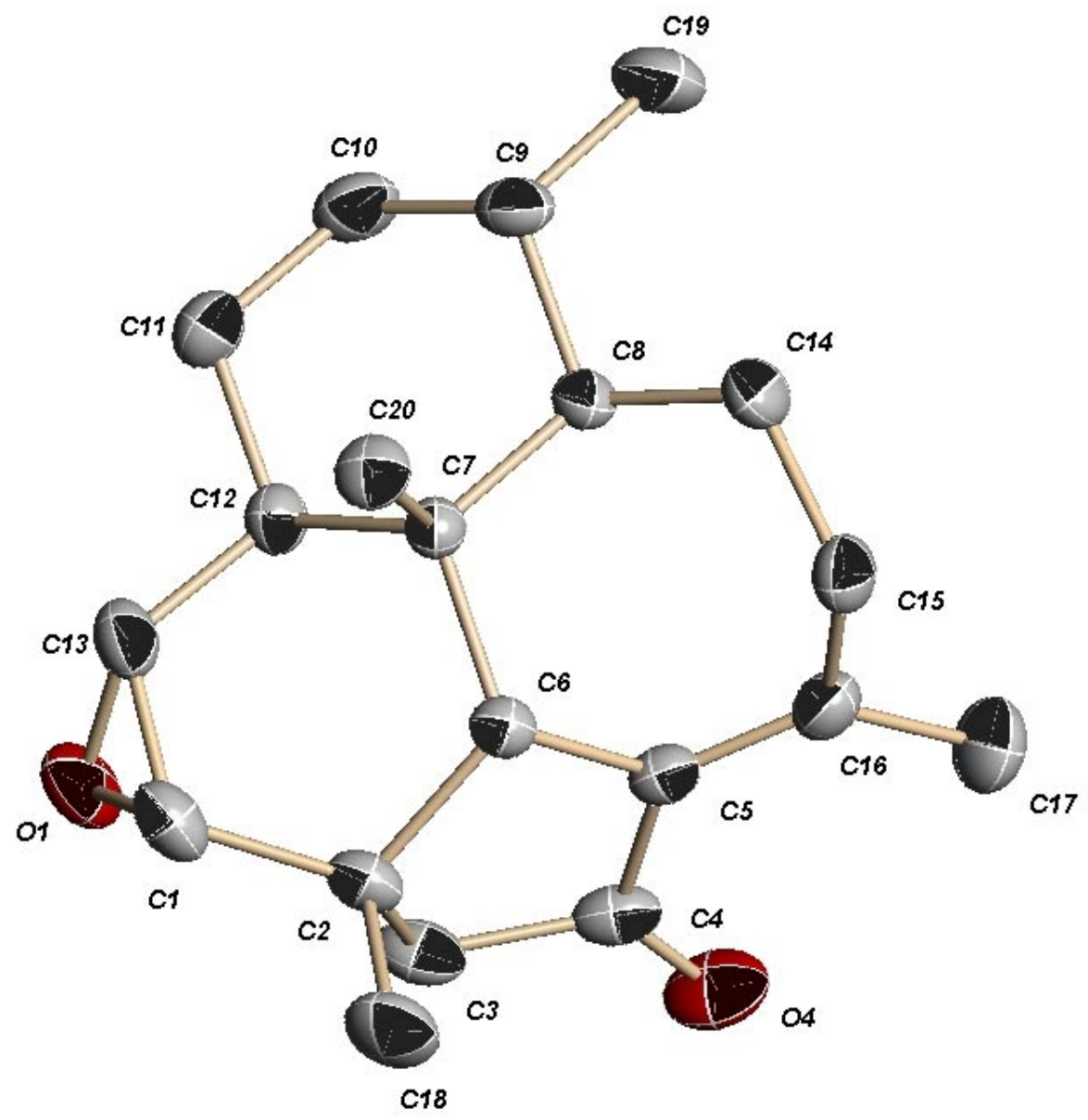

ORTEP diagram of compound $\mathbf{3 0}$ (Hydrogen atoms are omitted for clarity) 
Table 1. Crystal data and structure refinement for $\mathbf{3 0}$.

Identification code

Empirical formula

Formula weight

Temperature

Wavelength

Diffractometer used

Detector distance

Monochrometer used

Crystal size

Colour and habit

Crystal system

Space group

Unit cell dimensions

Volume

$\mathrm{Z}$

Density (calculated)

Absorption coefficient

$\mathrm{F}(000)$

Theta range for data collection

Completeness to theta $=27.48^{\circ}$

Scan type

Scan range

Exposure time
PD031256

C20 H28 O2

300.42

198(1) K

$0.71073 \AA$

Bruker AXS P4/SMART 1000

$5 \mathrm{~cm}$

Graphite

$0.2 \times 0.35 \times 0.4 \mathrm{~mm}^{3}$

Colourless, irregular

Monoclinic

$\mathrm{P} 2(1) / \mathrm{n}$

$\begin{array}{ll}\mathrm{a}=9.6273(7) \AA & \alpha=90^{\circ} \\ \mathrm{b}=16.1782(12) \AA & \beta=106.487(1)^{\circ} \\ \mathrm{c}=11.0361(8) \AA & \gamma=90^{\circ}\end{array}$

1648.2(2) $\AA^{3}$

4

$1.211 \mathrm{Mg} / \mathrm{m}^{3}$

$0.076 \mathrm{~mm}^{-1}$

656

2.30 to $27.48^{\circ}$

$97.9 \%$

$\omega$ and $\phi$

$0.3^{\circ}$

$10 \mathrm{~s}$ 
Index ranges

Standard reflections

collection

Crystal stability

Reflections collected

Independent reflections

System used

Solution

Hydrogen atoms

Absorption correction

Min./Max. transmission ratio

Refinement method

Data / restraints / parameters

Goodness-of-fit on $\mathrm{F}^{2}$

Final $\mathrm{R}$ indices [I>2sigma(I)]

$\mathrm{R}$ indices (all data)

Largest/mean shift/esd

Largest diff. peak and hole
$-12 \leq \mathrm{h} \leq 11,-21 \leq \mathrm{k} \leq 20,-14 \leq 1 \leq 12$

50 frames at beginning and end of data

no decay

11327

$3698[\mathrm{R}(\mathrm{int})=0.0251]$

\section{SHELXL 5.1}

Direct methods

Found, refined isotropically

\section{SADABS}

0.916

Full-matrix least-squares on $\mathrm{F}^{2}$

3698 / 0 / 311

1.042

$\mathrm{R} 1=0.0404, \mathrm{wR} 2=0.1044$

$\mathrm{R} 1=0.0592, \mathrm{wR} 2=0.1140$

$0.000 / 0.000$

0.297 and -0.150 e. $\AA^{-3}$

$$
\begin{aligned}
& \text { wR2 }=\left(\sum\left[\mathrm{w}\left(\mathrm{F}_{\mathrm{o}}^{2}-\mathrm{F}_{\mathrm{c}}^{2}\right)^{2}\right] / \sum\left[\mathrm{F}_{\mathrm{o}}^{4}\right]\right)^{1 / 2} \\
& \mathrm{R} 1=\sum|| \mathrm{F}_{\mathrm{o}}|-| \mathrm{F}_{\mathrm{c}}|| / \sum\left|\mathrm{F}_{\mathrm{o}}\right| \\
& \text { Weight }=1 /\left[\sigma^{2}\left(\mathrm{~F}_{\mathrm{o}}^{2}\right)+(0.0554 * \mathrm{P})^{2}+(0.3211 * \mathrm{P})\right] \\
& \text { where } \mathrm{P}=\left(\max \left(\mathrm{F}_{\mathrm{o}}^{2}, 0\right)+2 * \mathrm{~F}_{\mathrm{c}}^{2}\right) / 3
\end{aligned}
$$




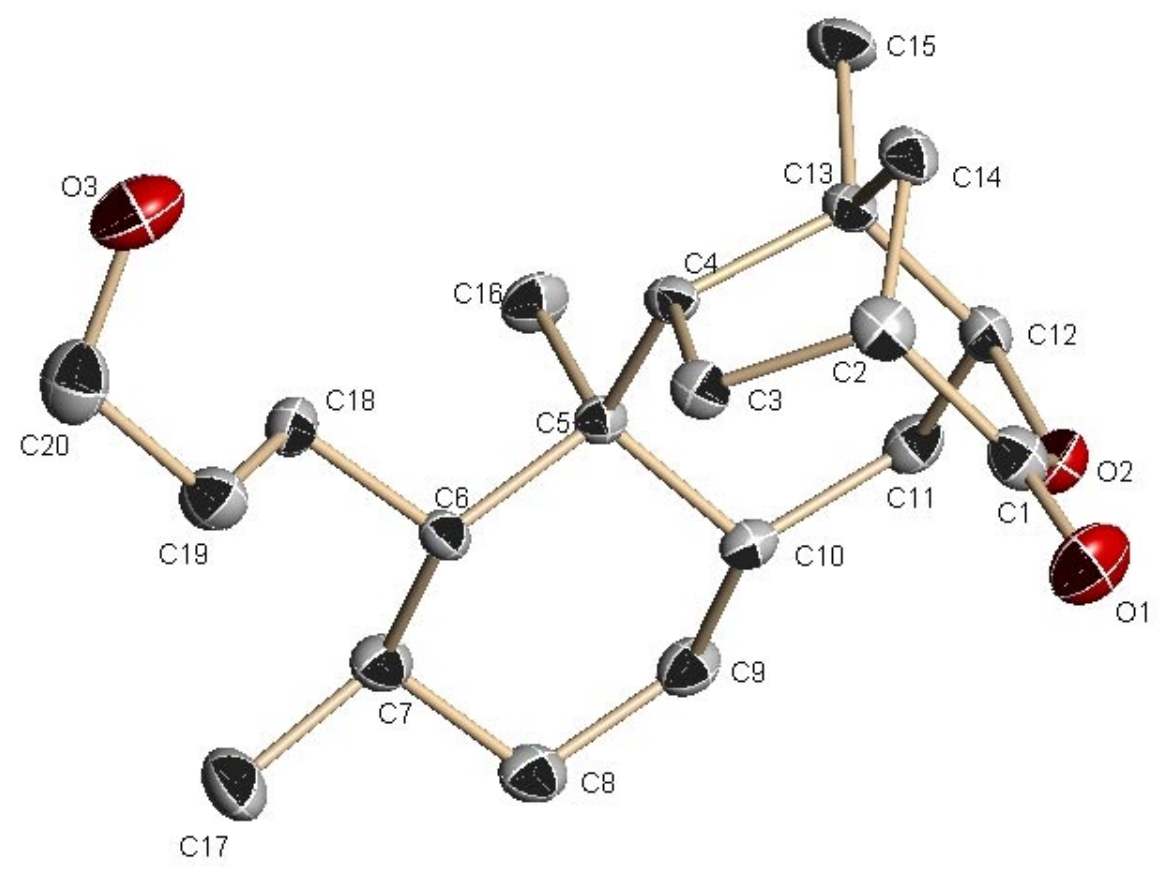

ORTEP diagram of compound $\mathbf{3 7}$ (Hydrogen atoms are omitted for clarity) 
Table 1. Crystal data and structure refinement for 37 .

Identification code

Empirical formula

Formula weight

Temperature

Wavelength

Diffractometer used

Detector distance

Monochromator used

Crystal size

Colour and habit

Crystal system

Space group

Unit cell dimensions

Volume

$\mathrm{Z}$

Density (calculated)

Absorption coefficient

$\mathrm{F}(000)$

Theta range for data collection

Completeness to theta $=27.48^{\circ}$

Scan type

Scan range

Exposure time
PD050494

$\mathrm{C} 20 \mathrm{H} 32 \mathrm{O} 3$

320.46

173(1) K

$0.71073 \AA$

Bruker AXS P4/SMART 1000

$5 \mathrm{~cm}$

Graphite

$0.45 \times 0.40 \times 0.10 \mathrm{~mm}^{3}$

Colourless, plate

Triclinic

P-1

$\begin{array}{ll}\mathrm{a}=6.6318(16) \AA & \alpha=99.427(5)^{\circ} \\ \mathrm{b}=10.293(3) \AA & \beta=96.076(4)^{\circ} \\ \mathrm{c}=13.750(3) \AA & \gamma=107.618(4)^{\circ}\end{array}$

870.3(4) $\AA^{3}$

2

$1.223 \mathrm{Mg} / \mathrm{m}^{3}$

$0.080 \mathrm{~mm}^{-1}$

352

1.52 to $27.48^{\circ}$

$91.5 \%$

$\omega$ and $\phi$

$0.3^{\circ}$

$10 \mathrm{~s}$ 
Index ranges

Standard reflections

collection

Crystal stability

Reflections collected

Independent reflections

System used

Solution

Hydrogen atoms

Absorption correction

Refinement method

Data / restraints / parameters

Goodness-of-fit on $\mathrm{F}^{2}$

Final $\mathrm{R}$ indices [I $>2 \operatorname{sigma}(\mathrm{I})]$

$\mathrm{R}$ indices (all data)

Largest/mean shift/esd

Largest diff. peak and hole
$-8 \leq \mathrm{h} \leq 8,-12 \leq \mathrm{k} \leq 12,-17 \leq 1 \leq 17$

50 frames at beginning and end of data

no decay

5904

5904

SHELXL 5.1

Direct methods

Found, refined isotropically

\section{SADABS}

Full-matrix least-squares on $\mathrm{F}^{2}$

5904 / 0 / 343

0.993

$\mathrm{R} 1=0.0693, \mathrm{wR} 2=0.1707$

$\mathrm{R} 1=0.0775, \mathrm{wR} 2=0.1743$

$0.000 / 0.000$

0.461 and -0.349 e. $\AA^{-3}$

$$
\begin{aligned}
& \text { wR2 }=\left(\sum\left[\mathrm{w}\left(\mathrm{F}_{\mathrm{o}}^{2}-\mathrm{F}_{\mathrm{c}}^{2}\right)^{2}\right] / \sum\left[\mathrm{F}_{\mathrm{o}}^{4}\right]\right)^{1 / 2} \\
& \mathrm{R} 1=\sum|| \mathrm{F}_{\mathrm{o}}|-| \mathrm{F}_{\mathrm{c}}|| / \sum\left|\mathrm{F}_{\mathrm{o}}\right| \\
& \text { Weight }=1 /\left[\sigma^{2}\left(\mathrm{~F}_{\mathrm{o}}^{2}\right)+(0.1339 * \mathrm{P})^{2}\right] \\
& \text { where } \mathrm{P}=\left(\max \left(\mathrm{F}_{\mathrm{o}}^{2}, 0\right)+2 * \mathrm{~F}_{\mathrm{c}}^{2}\right) / 3
\end{aligned}
$$

